\title{
USING CHRISTENSEN'S MODELS TO MAKE SENSE OF CHANGES IN THE CHINESE TELECOMMUNICATIONS EQUIPMENT SUPPLIER INDUSTRY
}

\author{
By \\ Wei Zhen \\ A thesis submitted to the Faculty of Graduate Studies and Research \\ in partial fulfillment of the requirements for the degree of \\ Master of Engineering in Telecommunications Technology Management \\ Department of Systems and Computer Engineering \\ Carleton University \\ Ottawa, Canada, K1S 5B6 \\ December 2004
}

(C) Copyright 2004 Wei Zhen 


$\begin{array}{ll}\begin{array}{l}\text { Library and } \\ \text { Archives Canada }\end{array} & \begin{array}{l}\text { Bibliothèque et } \\ \text { Archives Canada }\end{array} \\ \begin{array}{l}\text { Published Heritage } \\ \text { Branch }\end{array} & \begin{array}{l}\text { Direction du } \\ \text { Patrimoine de l'édition }\end{array} \\ \begin{array}{l}\text { 395 Wellington Street } \\ \text { Ottawa ON K1A ON4 }\end{array} & \begin{array}{l}\text { 395, rue Wellington } \\ \text { Ottawa ON K1A ON4 } \\ \text { Canada }\end{array}\end{array}$

Your file Votre référence

ISBN: 0-494-00771-0

Ourfile Notre référence

ISBN: 0-494-00771-0

NOTICE:

The author has granted a nonexclusive license allowing Library and Archives Canada to reproduce, publish, archive, preserve, conserve, communicate to the public by telecommunication or on the Internet, loan, distribute and sell theses worldwide, for commercial or noncommercial purposes, in microform, paper, electronic and/or any other formats.

The author retains copyright ownership and moral rights in this thesis. Neither the thesis nor substantial extracts from it may be printed or otherwise reproduced without the author's permission.
AVIS:

L'auteur a accordé une licence non exclusive permettant à la Bibliothèque et Archives Canada de reproduire, publier, archiver, sauvegarder, conserver, transmettre au public par télécommunication ou par l'Internet, prêter, distribuer et vendre des thèses partout dans le monde, à des fins commerciales ou autres, sur support microforme, papier, électronique et/ou autres formats.

L'auteur conserve la propriété du droit d'auteur et des droits moraux qui protège cette thèse. $\mathrm{Ni}$ la thèse ni des extraits substantiels de celle-ci ne doivent être imprimés ou autrement reproduits sans son autorisation.
In compliance with the Canadian

Privacy Act some supporting forms may have been removed from this thesis.

While these forms may be included in the document page count, their removal does not represent any loss of content from the thesis.
Conformément à la loi canadienne sur la protection de la vie privée, quelques formulaires secondaires ont été enlevés de cette thèse.

Bien que ces formulaires aient inclus dans la pagination, il n'y aura aucun contenu manquant.

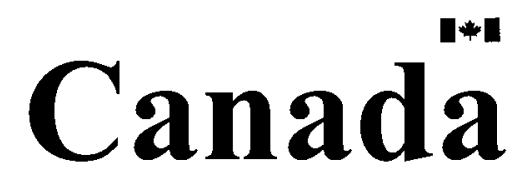




\begin{abstract}
The objective of this research is to use Professor Clayton M. Christensen's models on innovation to explain how Chinese suppliers of telecommunications equipment became serious global competitors in a relative short time. A chronology of the key events in the history of four Chinese suppliers of stored program control switches was used to identify two competitive regimes: a competitive isolation regime from 1985 to 1994 and (ii) a competitive convergence regime from 1995 to 2003. For each competitive regime, nine constructs emphasized by the innovation disruption and resources, processes and values models of innovation were used to compare Chinese and foreign equipment suppliers. Prior to 1985 there were no Chinese suppliers of telecommunications equipment. Today there are four that aggressively compete in China against joint ventures with foreign partners and foreign suppliers. One has moved to become a leading global supplier of telecommunications equipment in six product markets, another leads in one product market. The research is important because this phenomenon has received little attention in the literature.
\end{abstract}




\section{ACKNOWLEDGEMENT}

With this acknowledgement, I would like to express my deepest gratitude to all the people who were helpful and engaged, giving their energy and time for my research.

First of all, I would like to thank my supervisor, Professor Antonio J. Bailetti, for his great guidance through this research, fruitful discussions, and his highly appreciated feedback.

Last but not the least, I would like to thank my wife Lan, my family and friends for their supports and patience with me in the process of writing this thesis. 
ABSTRACT iii

ACKNOWLEDGEMENT ...................................................................................................iv

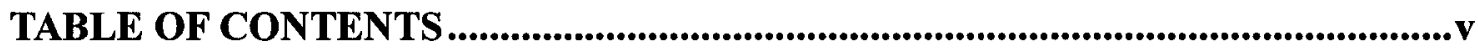

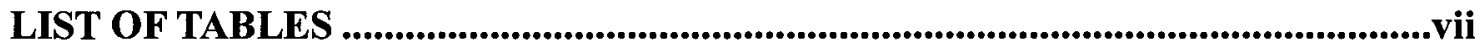

LIST OF FIGURES ...................................................................................... viii

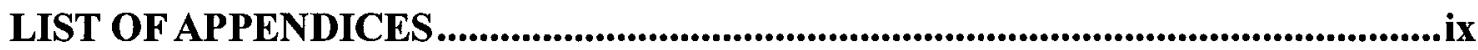

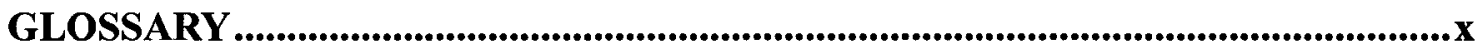

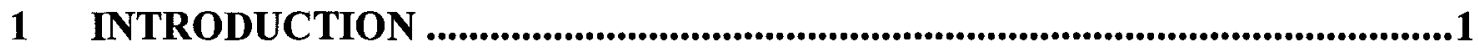

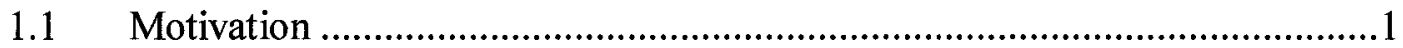

1.2 Research Objective.........................................................................4

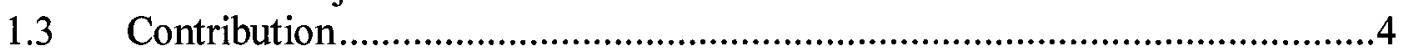

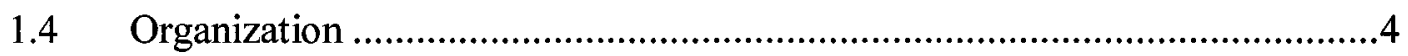

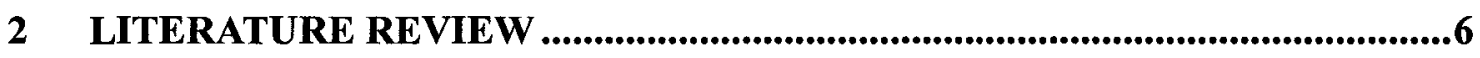

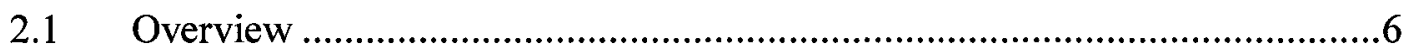

2.2 Core Innovation Theories .................................................................

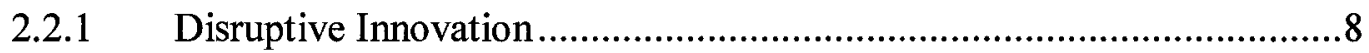

2.2.2 Resources, Processes, and Values .................................................. 12

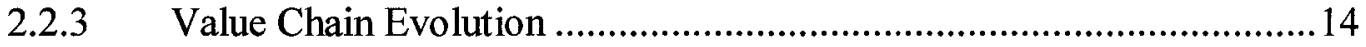

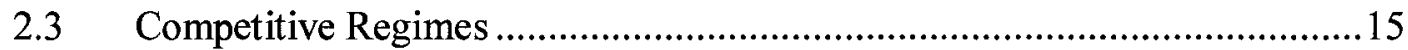

$2.4 \quad$ Chinese Telecommunications Market......................................................... 17

2.5 Performance Measures for an Innovation System .....................................19

2.6 Lessons Learned From the Literature Review .............................................19

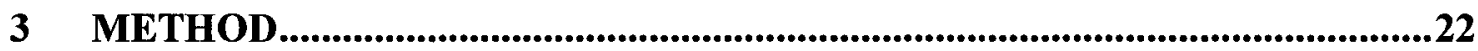

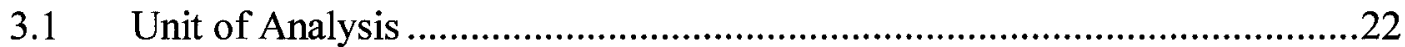

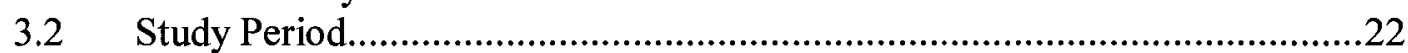

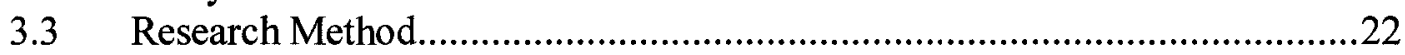

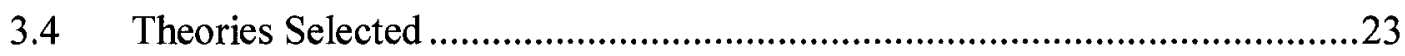

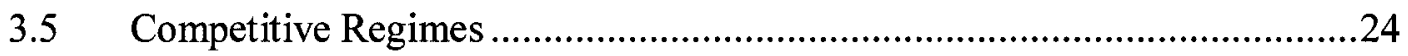

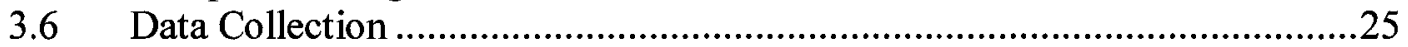

4 KEY EVENTS OF CHINESE EQUIPMENT SUPPLIERS.............................29

4.1 Datang Telecom Technology Co., Ltd. (DTT) .......................................29

4.2 Great Dragon Information Technology Co., Ltd. (GDT) ...............................31

4.3 Huawei Technologies (Huawei) ...............................................................34

4.4 Zhongxing Telecommunication Equipment Co., Ltd (ZTE)........................38

\section{COMPARING CHINESE AND ESTABLISHED EQUIPMENT SUPPLIERS 42}

$5.1 \quad$ Competitive Regimes Identified ..........................................................43 


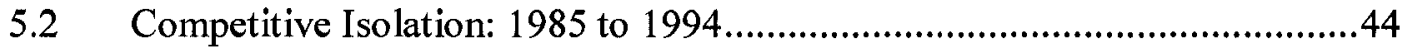

5.2.1 Disruptive Technology Perspective.................................................47

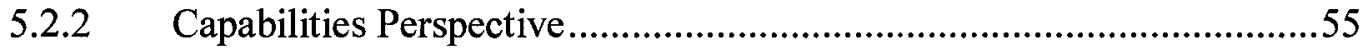

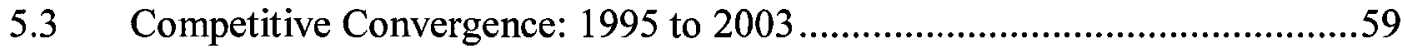

5.3.1 Disruptive Technology Perspective................................................65

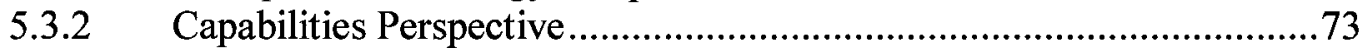

6 DISCUSSION OF RESULTS ........................................................................880

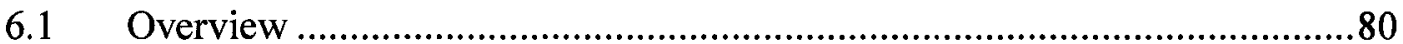

6.2 Answering the Research Question.....................................................82

7 CONCLUSIONS, LIMITATIONS AND SUGGESTIONS FOR FUTURE

RESEARCH.......................................................................................................8

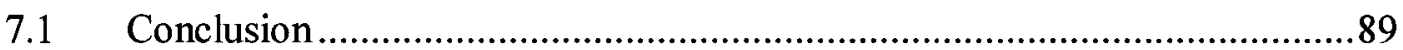

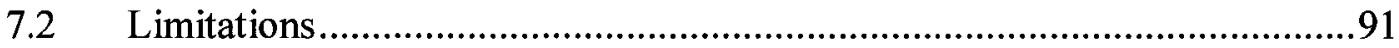

7.3 Suggestions for Future Research .......................................................92

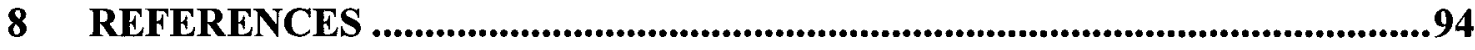

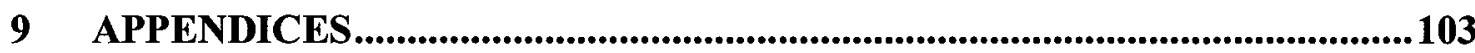




\section{LIST OF TABLES}

Table

Page

Table 1. Perspectives of Selected Studies...............................................................

Table 2: Types of Disruptive Innovations ..........................................................20

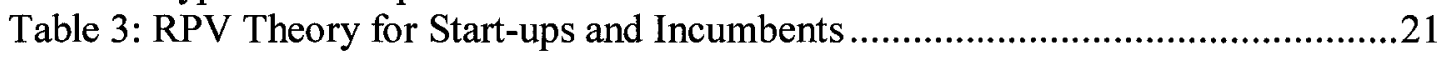

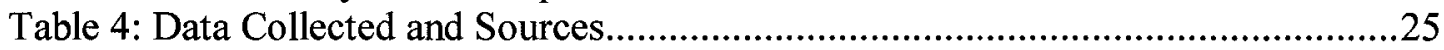

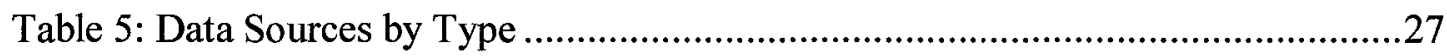

Table 6: The 1985-1994 Competitive Isolation Regime .........................................45

Table 7: Suppliers' First Deployments of SPC Switches in China ............................49

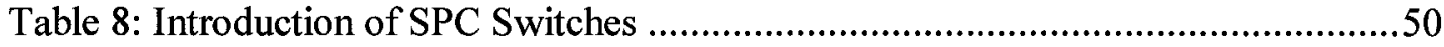

Table 9: The 1995-2003 Competitive Convergence Regime....................................60

Table 10: The First Deployment of Chinese Suppliers' High Capacity Switches .........66

Table 11: Countries to Which Chinese Suppliers Exported High Capacity Switches, and

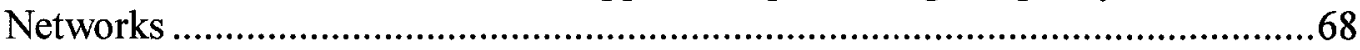

Table 12: Product Markets in Which Alcatel Shanghai Bell, BISC, and Chinese

Equipment Suppliers Operated as of 2003 ....................................................71

Table 13: Price Comparison (US \$ per Public Switched Telephone Network Line).....73

Table 14: Number of Sales and Service Offices in China as of 2003 .........................76

Table 15: Number of Chinese Suppliers' Offices Overseas as of 2003 ......................77

Table 16: Process Adopted by SPC Equipment Suppliers Operating in China .............78 


\section{LIST OF FIGURES}

Figure

Page

Figure 1: Disruptive Innovation Theory ........................................................ 11

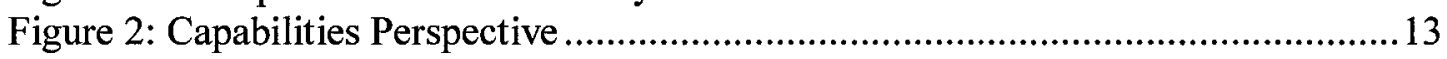

Figure 3: Performance Measures.......................................................................19

Figure 4: DTT's Annual Revenues and Net Profits from 1998 to $2003 . . . \ldots \ldots \ldots \ldots \ldots \ldots . . . . . .31$

Figure 5: Huawei's Annual Revenues from 1992 to 2003 ........................................38

Figure 6: ZTE's Annual Revenue and Profits from 1996 to 2003 ..............................41

Figure 7: Annual Revenue of the Joint Ventures Shanghai Bell and BISC and Chinese suppliers DTT, GDT, Huawei and ZTE........................................................67

viii 


\section{LIST OF APPENDICES}

Appendix

Page

Appendix A1: Key Events in the History of the Datang Telecom Technology Co., Ltd.

(DTT) 103

Appendix A2: Products and Technology Developed by the Datang Telecom

Technology Co., Ltd. (DTT) 104

Appendix A3: Employment, Revenue and Profits for the Datang Telecom Technology

Co., Ltd. (DTT).... 106

Appendix B1: Key Events in the History of the Great Dragon Information Technology

Co., Ltd. (GDT) 107

Appendix B2: Products and Technologies Developed by the Great Dragon Information

Technology Co., Ltd. (GDT)........................................................................... 108

Appendix B3: Employment, Revenue and Profits for the Great Dragon Information

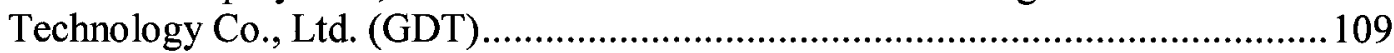

Appendix C1: Key Events in the History of Huawei Technologies (Huawei) ...............110

Appendix C2: Products and Technologies Developed by Huawei Technologies (Huawei)

Appendix C3: Employment, Revenue and Profits for Huawei Technologies (Huawei). 117

Appendix D1: Key Events in the History of the Zhongxing Telecommunication

Equipment Co., Ltd. (ZTE)

Appendix D2: Products and Technologies Developed by Zhongxing

Telecommunication Equipment Co., Ltd. (ZTE) 123

Appendix D3: Employment, Revenue and Profits for Zhongxing Telecommunication

Equipment Co., Ltd. (ZTE) ........................................................................ 126

Appendix E: Ranking of Shanghai Bell, BISC, Huawei, ZTE, DTT and GDT in the

Chinese TOP 100 Electronics Company List (RMB: Billion)...

Appendix F: Number of Chinese Subscribers to Fixed, Mobile and Internet Services

$(1991-2003)$

Appendix G: Investment in Telecommunications Made by the Ministry of Information

Industry of China*

Appendix H: International Standards 


\section{GLOSSARY}

$3 \mathrm{G}$ the $3^{\text {rd }}$ generation of mobile telecommunications

ADSL Asymmetric Digital Subscriber Line

AN Access Network

ASIC Application-Specific Integrated Circuit

BSS Business Support Systems

CDMA Code Division Multiple Access

CDMA WLL Code Division Multiple Access Wireless Local Loop

CMM Capability Maturity Model

CPC Collaborative Product Commerce

CPRI Common Public Radio Interface

DSLAM Digital Subscriber Line Access Multiplexer

DSP Digital Signal Processing

DWDM Dense Wavelength Division Multiplex(ing)

ERP Enterprise Resource Planning

ECC Engineering Change Control

GSM Global System for Mobile Communications

GPRS General Packet Radio Service

IC Integrated Circuit

IN Intelligent Network

IP Internet Protocol

IPD Integrated Product Development

IPDSLAM DSLAM based on IP and Enternet 


$\begin{array}{ll}\text { ISDN } & \text { Integrated Services Digital Network } \\ \text { ISC } & \text { Integrated Supply Chain } \\ \text { LAN } & \text { Local Area Network } \\ \text { MMS } & \text { Multimedia Messaging Service } \\ \text { MSTP } & \text { Multi-Service Transport Platform } \\ \text { NGN } & \text { Next Generation Network } \\ \text { NVQ } & \text { National Vocational Qualification } \\ \text { OADM } & \text { Optical Add/Drop Multiplexer } \\ \text { OSS } & \text { Operational Support System } \\ \text { PABX } & \text { Private Automatic Branch Exchange } \\ \text { PBX } & \text { Private Branch (telephone) Exchange } \\ \text { PCS } & \text { Personal Communications System (Services) } \\ \text { PHS } & \text { Personal Handyphone System } \\ \text { PSTN } & \text { Public Switched Telephone Network } \\ \text { SDH } & \text { Synchronous Digital Hierarchy } \\ \text { SIM } & \text { Subscriber Identity Module } \\ \text { SMS } & \text { Short Message Service } \\ \text { SPC } & \text { Stored Program Control } \\ \text { SS7 } & \text { Signaling System 7 } \\ \text { SSP } & \text { Service Switching Point } \\ \text { STM } & \text { Synchronous Transfer Module } \\ \text { STP } & \text { Signal Transfer Point } \\ & \end{array}$

TD-SCDMA Time Division Synchronous Code Division Multiple Access 
UIM User Identity Module

UMTS Universal Mobile Telecommunication System

VPN Virtual Private Network

VoIP Voice over Internet Protocol

WCDMA Wideband Code Division Multiple Access

WCDMA R4 WCDMA R4 version (based on Softswitch technology)

WDM Wavelength Division Multiplex

WMS Warehouse Management System

WVPN Wireless Virtual Private Network 


\section{INTRODUCTION}

\subsection{Motivation}

The research question is: Can two of Christensen's models -- disruptive innovation and resources, processes, and values, explain how Chinese makers of telecommunications equipment became serious global competitors in less than 20 years?

This research examines the four largest Chinese suppliers of stored program control (SPC) switches: Datang Telecom Technology Co., Ltd. (DTT), the Great Dragon Information Technology Co., Ltd. (GDT), Huawei Technologies (Huawei), and Zhongxing Telecommunication Equipment Co., Ltd (ZTE). The research focuses on how these four Chinese suppliers (i) competed in China against the two largest SPC switch manufacturers that had foreign joint venture partners: Shanghai Bell, an Alcatel joint venture, and Beijing International Switching System Co. (BISC), a Siemens joint venture, and (ii) competed globally against well established suppliers of telecommunications equipment such as Alcatel, Cisco, Ericsson, Fujitsu, Lucent, NEC, Nokia, Nortel Networks, and Siemens.

The motivation for this research was twofold. First, the fast growth from 1985 to 2003 of two Chinese telecommunications equipment suppliers: Huawei and ZTE requires appropriate scrutiny. The success of these two Chinese suppliers threatens 
well established companies' plans to dominate the global and China markets for telecommunications equipment.

ZTE started operations in 1985 and Huawei in 1988. In ten years, Huawei became the number one supplier of telecommunications equipment in China. In 1998, Huawei's annual revenues exceeded those of the top two telecommunications equipment suppliers that had foreign joint venture partners: Shanghai Bell and BISC. Moreover, in 2002 and 2003, Huawei's and ZTE's revenues exceeded those of Shanghai Bell and BISC (Chinese Top 100 Electronics Company List, 2003).

A decade ago, the possibility that any of the four Chinese equipment suppliers could pose a serious threat to established global suppliers of telecommunications equipment such as Alcatel, Cisco, Ericsson, Fujitsu, Lucent, NEC, Nokia, Nortel Networks, and Siemens seemed improbable. Today, Chinese suppliers compete aggressively against these well established global telecommunications suppliers globally and their joint ventures in China.

Reputable market share tracking firms ranked Huawei the number one supplier in the global market for new extended switching equipment from 2001 to 2003 (Dittberner, 2004a), the number one supplier in the global market for new generation networks in the first half of 2004 (Dittberner, 2004b), the number two supplier in the global market for digital subscriber line access multiplexers in 2003 (Gartner, 2003), the number three supplier in the global market for long distance wavelength division 
multiplexers (RHK, 2004a), and the number four supplier in the global market for optical transmission (RHK, 2004b). RHK ranked Huawei and ZTE the number three and eight suppliers in the global market for integrated access networks (RHK, 2004c).

Executives of North American and European vendors of telecommunications equipment have become increasingly concerned about the head to head competition from Chinese suppliers (Hamblen, 2004).

The second motivation for this research was the desire to use the two models popularized by Professor Clayton Christensen to help explain the growth of an industry anchored around the four Chinese suppliers of telecommunications equipment. Over the last decade, Christensen and his co-authors have published at least three books (Christensen, 1997; Christensen and Raynor, 2003; Christensen, Anthony and Roth, 2004) and seven articles (Bower and Christensen, 1995;

Christensen and Rosenbloom, 1995; Christensen and Overdorf, 2000; Christensen, Raynor and Verlinden, 2001; Christensen, Johnson, and Rigby, 2002; Christensen, Verlinden and Westerman, 2002) describing the phenomenon of disruptive innovation. Recently, Christensen, Anthony and Roth (2004, xiii-xxxix) suggests that two core theories of innovation (i) disruptive innovation theory, and (ii) capabilities or resources, processes and values theory can be used to make sense of the past and predict the future. The second motivation for this research originated from the realization that there is a lack of published studies that use the models that 
Christensen and his coauthors describe that have been published by authors unrelated to Christensen.

\subsection{Research Objective}

The objective of this research is to use models to explain how Chinese suppliers of telecommunications equipment became serious competitors worldwide in a relative short time.

\subsection{Contribution}

This research makes two contributions. First, the thesis illustrates how to apply a step-by-step method to explain changes in a technology driven industry.

The second contribution that this thesis makes is that it complements systems of innovation studies on complex products and systems such as SPC switches.

\subsection{Organization}

The thesis is organized into seven chapters. The first chapter is the introduction, the second provides a literature review, the third describes the research method, and the fourth chapter provides an overview and a chronology of key events for the four Chinese suppliers of telecommunications equipment. In Chapter 5, Chinese and foreign suppliers of stored program control switches are compared in terms of nine factors highlighted in two models of innovation proposed by Professor Clayton Christensen. Chapter 6 discusses the results and Chapter 7 provides the conclusions, 
describes the limitations of this research, and makes suggestions for future research. 


\section{LITERATURE REVIEW}

\section{Structure of Literature Review}

Section 1 provides an overview of Professor Clayton Christensen's work. Section 2 examines the disruptive innovation theory; the resource, processes and value theory; and the value chain theory. Section 3 explains the three competitive regimes of disruptive technologies: competitive isolation; competitive convergence; and competitive disruption. Section 4 introduces the literature on Chinese suppliers of stored program controlled switches. Section 5 introduces the measures for an innovation system. Section 6 develops the lessons learned from the literature review.

\subsection{Overview}

Christensen's work on innovations is popular. This section has been organized around three core theories: disruptive innovation; resource, processes and value (RPV); and the value chain.

The disruptive innovation theory builds on Bower and Christensen (1995), Christensen and Overdorf (2000) and Christensen, Johnson and Rigby (2002). The resource, processes and value theory builds on the work of Christensen and Overdorf (2000). The value chain theory builds on the study of Christensen, Raynor and Verlinden (2001). In addition, the book "Seeing what's next? using the theories of innovation to predict industry change" written by Christensen, Anthony and Roth (2004) describes all these three core theories. 
Table 1. Perspectives of Selected Studies

\begin{tabular}{|c|c|c|c|}
\hline & Samples & Theory & Key Points \\
\hline $\begin{array}{l}\text { Bower \& } \\
\text { Christensen } \\
\text { (1995) }\end{array}$ & $\begin{array}{l}\text { Hard drives; } \\
\text { Sony's portable } \\
\text { radios; personal } \\
\text { computers; } \\
\text { copy machines; } \\
\text { excavators; }\end{array}$ & $\begin{array}{l}\text { Disruptive } \\
\text { innovation } \\
\text { Resources, } \\
\text { processes } \\
\text { and values }\end{array}$ & $\begin{array}{l}\text { The technological changes that } \\
\text { damage established companies are } \\
\text { usually not radically new or difficult } \\
\text { from a technological point of view. } \\
\text { - Established companies usually choose } \\
\text { to go up-market with sustaining } \\
\text { technologies and enter market } \\
\text { segments whose profit margins are } \\
\text { high. } \\
\text { It's difficult to divert resources from } \\
\text { known customer needs in established } \\
\text { markets to markets and customers that } \\
\text { seem insignificant or do not exist } \\
\text { Once the entrant companies have } \\
\text { secured a foothold in the market and } \\
\text { improved the performance of their } \\
\text { products, they aim at the established } \\
\text { markets above them. }\end{array}$ \\
\hline $\begin{array}{l}\text { Christensen } \\
\text { \& Overdorf } \\
(2000)\end{array}$ & $\begin{array}{l}\text { Toyota' low } \\
\text { end market; } \\
\text { Charles } \\
\text { Schwab's } \\
\text { discount } \\
\text { broker; }\end{array}$ & $\begin{array}{l}\text { Resources, } \\
\text { processes } \\
\text { and values } \\
\text { Disruptive } \\
\text { innovations }\end{array}$ & $\begin{array}{l}\text { Company's resources, processes and } \\
\text { values determine its actions in the } \\
\text { market. } \\
\text { - Disruptive innovations create an } \\
\text { entirely new market through the } \\
\text { introduction of a new kind of product } \\
\text { or service that's actually worse. }\end{array}$ \\
\hline
\end{tabular}




\begin{tabular}{|c|c|c|c|}
\hline $\begin{array}{l}\text { Christensen, } \\
\text { Raynor \& } \\
\text { Verlinden } \\
\text { (2001) }\end{array}$ & $\begin{array}{l}\text { IBM, Ford, } \\
\text { GM, RCA, } \\
\text { Xerox, AT\&T, } \\
\text { Alcoa, } \\
\text { Compaq, } \\
\text { Standard Oil, } \\
\text { U.S. Steel. }\end{array}$ & Chain & $\begin{array}{l}\text { - When the product is not good enough, } \\
\text { being an integrated company is critical } \\
\text { to success. } \\
\text { - Once a modular architecture and the } \\
\text { requisite industry standard have been } \\
\text { defined, the integration is no longer } \\
\text { crucial to a company's success. }\end{array}$ \\
\hline $\begin{array}{l}\text { Christensen, } \\
\text { Johnson \& } \\
\text { Rigby } \\
\text { (2002) }\end{array}$ & $\begin{array}{l}\text { Apple II, } \\
\text { Xerox; Apple's } \\
\text { Newton vs. } \\
\text { Palm's Pilot; } \\
\text { IBM's } \\
\text { ViaVoice } \\
\text { product; Xerox } \\
\text { vs. HP. }\end{array}$ & $\begin{array}{l}\text { Disruptive } \\
\text { innovation. }\end{array}$ & $\begin{array}{l}\text { Successful disruptive innovators } \\
\text { always target customers who welcome } \\
\text { simple products. } \\
\text { - Once a viable disruptive growth } \\
\text { strategy has been defined, three } \\
\text { classes of factors - resources, } \\
\text { processes and values need to be } \\
\text { managed carefully. }\end{array}$ \\
\hline
\end{tabular}

\subsection{Core Innovation Theories}

\subsubsection{Disruptive Innovation}

The disruptive innovation theoretical perspective examines situations in which new organizations use relatively simple, convenient, low-cost innovations, to successfully compete with incumbent companies. The disruptive innovation perspective holds that established companies have a high probability of beating new entrant attackers when the competition is anchored around sustaining innovations. Established companies, however, almost always lose to attackers armed with disruptive innovations (Christensen, Anthony, \& Roth, 2004). 
Disruptive innovations create an entirely new market through the introduction of a new kind of product or service, one that's actually worse, initially, as judged by the performance metrics that mainstream customers' value (Christensen \& Overdorf, 2000).

Sustaining innovations are what move companies along established improvement trajectories. They are improvements to existing products on dimensions historically valued by customers (Christensen et al., 2004). Telecommunications switches that process faster, construction materials that last longer, and telescopes with incrementally or dramatically clearer images are all sustaining innovations. Disruptive innovations introduce a new value proposition. They either create new markets or reshape existing markets. There are two types of disruptive innovations: new market and low-end. New market disruptive innovation occur when characteristics of existing products limit the number of potential consumers or force consumption to take place in inconvenient, centralized settings (Christensen et al., 2004). Low-end disruptive innovations occur when existing products and services are "too good" and hence overpriced relative to the value existing customers can use.

Figure 1 is reproduced from Christensen, Anthony and Roth's recent book titled Seeing What's Next. Figure 1 illustrates what is meant by sustaining innovations, new market disruption, and low-end disruptions. 


\subsubsection{Establishing a new market as a base for disruption}

It is much easier to target potential customers who are not buying at all than to steal customers from an entrenched competitor (Christensen, Johnson \& Rigby, 2002). Instead of competing against a well established company, a new entrant can compete against non consumption.

\subsubsection{Low cost as a base for disruption}

For a low end disruptive strategy to succeed, it must (i) target the least-demanding tiers of a market and (ii) the business model must enable the entrant to compete profitably while pricing at deep discounts (Christensen et al., 2002). 
Figure 1: Disruptive Innovation Theory

\section{The Disruptive Innovation Theory}

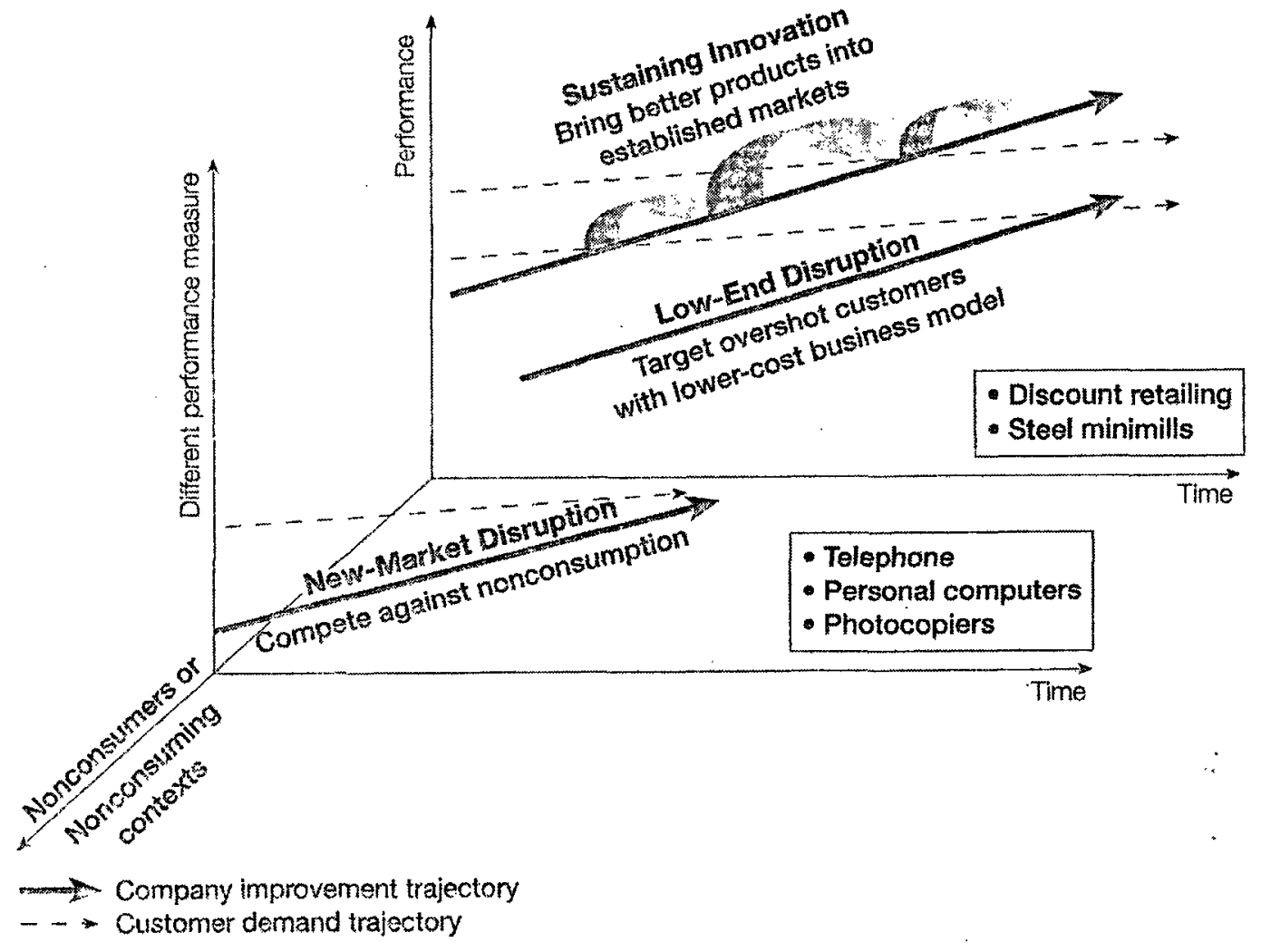

Source: (Christensen et al., 2004: xvi)

The only way a corporation can maintain its growth is by launching new growth business when the core units are strong (Christensen et al., 2002). 


\subsubsection{Resources, Processes, and Values}

The resources, processes, and value (RPV) theoretical perspective focuses on company capabilities to explain why established companies find difficult to react to disruptive innovations.

Figure 2 is reproduced from Christensen et al. (2004). It illustrates a sample of resources, processes and values. Christensen define resources as things or assets that organizations can buy or sell, build or destroy, like people, equipment, technologies, and cash, and the less tangible ones like product designs, information, brands and relationships with suppliers, distributors, and customers. Processes are the established patterns of work by which companies transform inputs to outputs of greater worth. Values determine the criteria by which organizations allocate their resources. Christensen et al. (2004) define an organization's value as the standards by which employees set priorities that enable them to judge whether a customer is more important or less important, whether an idea for a new product is attractive or marginal, and so on. 
Figure 2: Capabilities Perspective

Resources, Processes, and Values
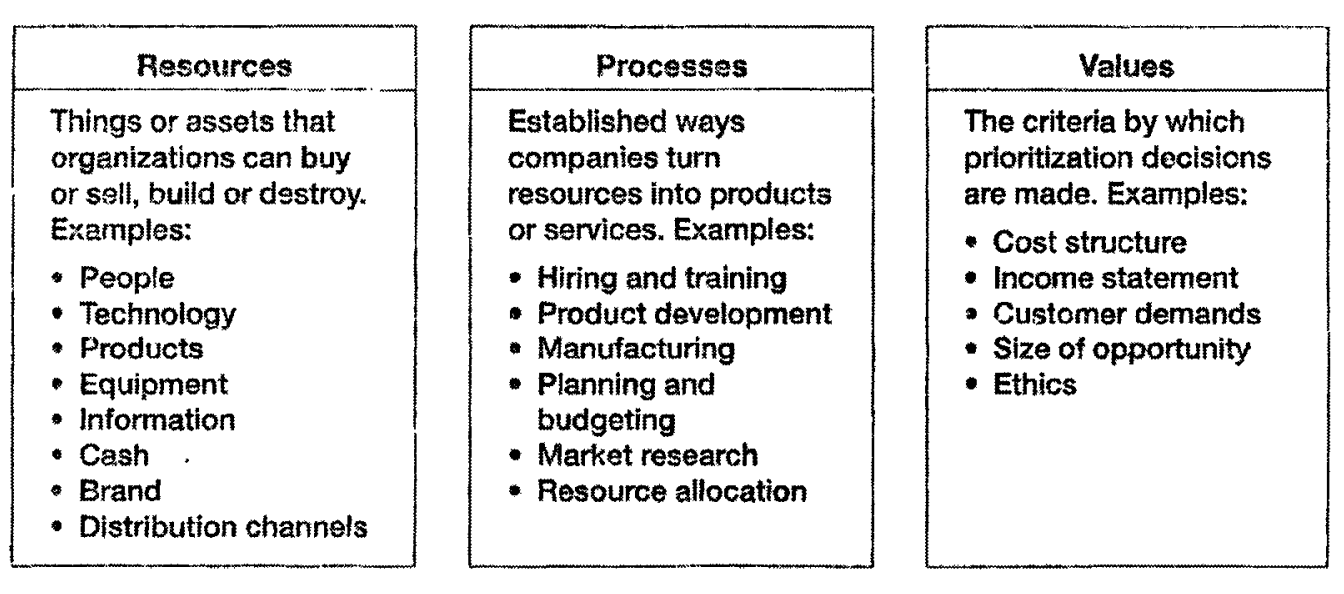

Source: (Christensen et al., 2004: xviii)

The RPV theory argues that organizations successfully tackle opportunities when they have the resources to succeed, when their processes facilitate what needs to get done, and when their values allow them to give adequate priority to that particular opportunity in the face of all other demands that compete for the company's resources. Incumbent firms master sustaining innovations because their values prioritizing them, and their processes and resources are designed to tackle precisely those types of innovations. Incumbent firms fail in the face of disruptive innovations because their values will not prioritize disruptive innovations, and the firm's existing processes do not help them get done what they need to get done (Christensen et al., 2004). 
When a company's processes and values are being formed in its early middle years, the founder typically has a profound impact. The factors that define an organization's capabilities and disabilities evolve over time - they start in resources; then move to visible, articulated processes and values, and migrate finally to culture. When the organization's capabilities reside primarily in its people, changing capabilities to address the new problems is relatively simple. But when the capabilities have come to reside in processes and values, and especially when they have become embedded in culture, change can be extraordinarily difficult (Christensen \& Overdorf, 2000).

\subsubsection{Value Chain Evolution}

The value chain evolution perspective examines whether or not a company has made the right organizational design decisions to compete successfully. A company can choose to integrate, executing most of the activities themselves, or it can choose to specialize and focus on a narrow range of activities, relying on suppliers and partners to other elements of value added (Christensen et al., 2004).

The theory suggests companies ought to control any activity or combination of activities within the value chain that drive performance along dimensions that matters most to customers. Directly controlling, or integrating, an activity gives companies the ability to run experiments and push the frontier of what is possible. Integration gives firms a full platform to run experiments to solve problems caused by unpredictable "interdependencies" between activities. These same interdependencies can frustrate specialist firms that try to focus on a single piece of product's or 
service's value chain. When a specialist's piece interacts unpredictably with components that other companies design and make, it typically results in poor performing, unreliable products.

The performance improvements that integration provides come at a cost, however. Integrated architectures tend to be relatively inflexible. Integrated companies tend to react relatively slowly. Therefore, the theory suggests that companies ought to outsource activities that do not influence the characteristics of a product or service that customers deem (or will deem) most critical (Christensen et al., 2004).

Modular architectures facilitate (or permit) disintegration sacrifice raw performance in the name of speed to market, responsiveness, and convenience. This sacrifice allows companies to customize their products by upgrading individual subsystems without having to redesign an entire product. They can mix and match components from best-of breed suppliers to respond conveniently to individual customers' needs (Christensen et al., 2004).

\subsection{Competitive Regimes}

As for the disruptive innovations, Adner (2002) pointed out that the demand-side factors that drive the emergence of competition remain largely unstudied in Christensen's explanations. So in his article, Adner developed a demand-based view of technology competition by formally modeling the demand environment in shaping competitive dynamics. 
The structure of demand is characterized by two elements of the relationship between market segment preferences: preference overlap and preference symmetry. Preference overlap refers to the extent to which development activity that is valued in one segment is also valued in another segment. Preference symmetry refers to the symmetry of this overlap, the relative size of the functional 'shadows' that segments cast on each other.

Three distinct dynamics emerge during the course of the analysis. Under demand conditions of low preference overlap, the development dynamics lead to competitive isolation, a pure partitioning of the market between the technologies, such that each focuses exclusively on its own segment. As preference overlap increases, isolation breaks down and the development dynamics lead to the emergence of two distinct classes of competition. When segment preferences are symmetric we observe competitive convergence, in which each technology's development is directed at expanding its appeal not only in its own home market but in its rival's as well. When segment preferences are asymmetric we observe competitive disruption, in which one firm maintains dominance of its home market while displacing its rival from the rival's market (Adner, 2002). 


\subsection{Chinese Telecommunications Market}

DeWoskin (2001) describes the situation of the Chinese telecommunications market of the early 1990 's. Subscriber satisfaction was low, and the installation of a fixed line often took six months or longer. Installing a single fixed line carried a 5,000 RMB cost, and often another 5,000 RMB was needed as an expediting fee.

DeWoskin (2001) also mentions that the idea to use telecommunications equipment suppliers to promote the development of non-joint venture capability in China was discussed openly in 1977. The fast-growing network equipment market, and four companies were identified as key exponents of this strategy, Julong (GDT), Datang (DTT), and Zhongxing (ZTE) and Huawei. They were affectionately referred to in the press as juda zhonghua, "the colossus China."

Zhang and Igel ( 2001) studied these four Chinese suppliers with two joint ventures: Shanghai Bell and BISC. They found that low cost products and government assistance were important to Chinese suppliers' strategies while foreign joint ventures relied on foreign companies.

All six manufacturers (Shanghai Bell, BISC, GDT, DTT, ZTE and Huawei) emphasize cost control because of decreasing product prices and rising R\&D costs. The price of SPC switches in China is now (in 2001) only one-tenth of what it was in the early 1980 s. On the other hand, Huawei and ZTE spent $10 \%$ of their sales on 
R\&D activities; and 70\% of ZTE's R\&D budget was invested in software design and development. Because of the higher manufacturing cost of the EWSD, the JV firm BISC could not compete with Huawei's C\&C08 and ZTE's ZXJ10 at a capacity of less than 6,000 lines. BISC, therefore, lost its markets in rural areas to the products designed by Chinese-owned firms that were cheaper.

In addition, the government has tried to decrease the import of SPC switches. It encouraged telephone operators to use products from national manufacturers. In 1997, the Chinese government required banks to provide buyer loan schemes to Chinese SPC switch producers. This allowed Huawei to obtain a credit of 3,850 million RMB for its customers from the Construction Bank of China.

BISC sent its engineers and technicians to Germany to participate in the design and development of the EWSD version 13. The Chinese engineers were made responsible for the specifications of products sold in China. After completing the development of the new switch in Germany, the product was transferred to the Chinese market.

In 1992, the Chinese-owned firms held only $1.1 \%$ of the market share of central office exchanges. It is just in recent years that domestic firms have increased their market share substantially. Chinese designed SPC switches have gained more than half of the national market share since 1997. Facing strong challenges from domestic firms and lower profit, some foreign firms, such as Fujitsu and NEC, have withdrawn 
from China's SPC switch market, and a few Western SPC switch producers have been pondering leaving as well (Zhang \& Igel, 2001).

\subsection{Performance Measures for an Innovation System}

Carlsson provides the measures of system performance and data on company performance: when interested in the performance of an innovation system, we may evaluate how each individual part of a system performs (e.g. the firms, the educational system, and the capital market), but the main focus is on the total system (Carlsson, Jacobsson, Holmen, \& Rickne, 2002).

Figure 3 is reproduced from Carlsson et al. (2002). The Figure provides examples of the indicators attributable to knowledge generation, knowledge diffusion, and knowledge use.

Figure 3: Performance Measures

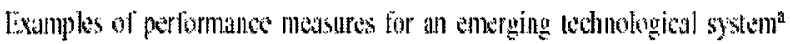

\begin{tabular}{|c|c|c|}
\hline Indicators of generation of kinenledge & Indicators of the diffusion of knowledge & 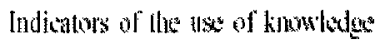 \\
\hline Number of fatents & Timing the stage of derelipment & Limployment \\
\hline Number of engincers or scientists & Regulatory acoptancs & Turnover \\
\hline Mobility of professinnals & $\begin{array}{l}\text { Number of parinersinumber of } \\
\text { distrithution licenses }\end{array}$ & Growilh \\
\hline $\begin{array}{l}\text { Teclnolugical ditersily c.g. number } \\
\text { of teclnolagieal ficks }\end{array}$ & & Financial assets \\
\hline
\end{tabular}

\subsection{Lessons Learned From the Literature Review}

This section summarizes the lessons learned from the literature review. 


\section{Disruptive innovations}

Disruptive innovations introduce a new kind of product or service that is actually worse, initially, as judged by the performance metrics that main stream customers' value (Christensen \& Overdorf, 2000).

Incumbents have a high probability of beating entrant attackers when the competition is about sustaining innovations, but almost always lose to attackers armed with disruptive innovations (Christensen et al., 2004).

There are two types of disruptive innovations. Table 2 compares these two innovation types.

Table 2: Types of Disruptive Innovations

\begin{tabular}{|l|l|l|}
\hline Type & Reasons and conditions & Targeted customers \\
\hline New market & $\begin{array}{l}\text { Available products are too } \\
\text { expensive, too complicated }\end{array}$ & Non-consumers \\
\hline Low end & $\begin{array}{l}\text { Good-enough and cheaper } \\
\text { products; enables entrants compete } \\
\text { profitably while pricing at deep } \\
\text { discounts }\end{array}$ & Less demanding customers \\
\hline
\end{tabular}

\section{Capabilities}

Companies successfully undertake an opportunity when they have resources to succeed, their processes facilitate what needs to get done, and their values allow them 
to give priority to opportunity (Christensen et al., 2004). Table 3 compares the capability perspective for startups with hat for incumbents.

Table 3: RPV Theory for Start-ups and Incumbents

\begin{tabular}{|l|l|l|}
\hline & Start-ups & Incumbents \\
\hline Locus & Resources & Processes and Values \\
\hline Change of capabilities & Simple & Difficult \\
\hline Founder's influence & Profound & - \\
\hline
\end{tabular}

\section{Value Chain Evolution}

Companies need to control the combination of activities that drive performance along dimensions that matters most to customers (Christensen et al., 2004).

\section{Competitive Regimes}

Three competitive regimes: competitive isolation, competitive convergence, and competitive disruption regimes exist according to the technologies interactions.

\section{Performance Indicators}

Last, performance of a system of innovation can be measured by examining indicators for knowledge generation, diffusion and use (Carlsson et al., 2002). 


\section{METHOD}

\subsection{Unit of Analysis}

The unit of analysis is a Chinese supplier of telecommunications equipment.

\subsection{Study Period}

The study period is from February 1985 to December 2003.

The start of the study period is marked by the month and year in which the first Chinese supplier of telecommunications equipment was founded. ZTE was founded in February 1985.

The end of the study period was marked by the month in which the researcher stopped collecting data. Data was collected up to December 2003.

\subsection{Research Method}

The research method used in the thesis is comprised of five iterative steps:

1. For each of the four Chinese suppliers, describe the salient changes since the company was founded and provide data on company performance. The salient changes include newsworthy information about markets, product or product lines, product performance, technologies, employment etc.

2. Identify competitive regimes from the information obtained from step 1 .

3. Select the theories that will be used in this research. 
4. For each regime, compare Chinese suppliers with established foreign suppliers using the constructs highlighted by the theories selected in step 3 .

5. Use the chronologies of key events prepared in step 1 and the comparison prepared in step 4 to gain insights on how Chinese suppliers grew.

\subsection{Theories Selected}

The emergence of the use of theory to examine technology competition has risen to prominence as a result of Christensen's work that started in 1997 with his analysis of the hard drive industry (Christensen, 1997).

The three theories refer to as core theories of innovation by Christensen, Anthony and Roth (2004, p. xv) were selected initially for this study. These three stories are:

1. Disruptive innovation

2. Capabilities (i.e., resources, processes and values)

3. Value chain evolution

Constructs emphasized by each theoretical perspective were used to compare the salient characteristics of Chinese and established foreign suppliers. It was soon became evident that there was little publicly available information on the constructs selected for the value chain evolution theory. Thus, it was dropped from the analysis.

For the purpose of this research, the following constructs were selected: 
- Constructs emphasized by the disruptive technology perspective: (i) the market, (ii) the product that drives technological advances, and (iii) the factors that drive demand.

- Constructs emphasized by the capabilities perspective: (i) technology, (ii) brand, (iii) sales personnel, (iv) product development, (v) manufacturing, and (vi) priorities. The first three components focus on suppliers' resources. Components (iv) and (v) focus on suppliers' processes, and (vi) focuses on suppliers' values.

\subsection{Competitive Regimes}

According to the demand-based view of disruptive technologies, there are three distinct competitive regimes that arise under various configurations of demand: competitive isolation, competitive convergence, and competitive disruption. In a competitive isolation regime, technologies do not interact in the course of their evolution. In a competitive convergence regime, technologies evolve to compete head-on for the same customers. In a competitive disruption regime, one technology cedes dominance of its market to its rival technology (Adner, 2002). 


\subsection{Data Collection}

Table 4 identifies the data that was collected for this study and the data sources.

Table 4: Data Collected and Sources

\begin{tabular}{|c|c|c|}
\hline Variable & Data Collected & Data Source \\
\hline Product & $\begin{array}{l}\text { Product categories, } \\
\text { capability and quality }\end{array}$ & $\begin{array}{l}\text { DTT's website (http://www.datang.com); } \\
\text { GDT's website (http://www.gdt.com.cn); } \\
\text { Huawei's website } \\
\text { (http://www.huawei.com); ZTE's website } \\
\text { (http://www.zte.com.cn); People's Post } \\
\text { and Telecom Daily } \\
\text { (http://ermyd.cnii.com.cn/index.htm); } \\
\text { Communication Weekly Journal } \\
\text { (http://www.comm-weekly.com.cn); } \\
\text { China Information Almanacs 2001-2003 } \\
\text { (http://www.cia.org.cn); China Electronic } \\
\text { News (http://www.cena.com.cn) }\end{array}$ \\
\hline Technology & $\begin{array}{l}\text { Technology used for } \\
\text { existing products and } \\
\text { future standards }\end{array}$ & $\begin{array}{l}\text { DTT's website (http://www.datang.com); } \\
\text { GDT's website (http://www.gdt.com.cn); } \\
\text { Huawei's website } \\
\text { (http://www.huawei.com); ZTE's website } \\
\text { (http://www.Zte.com.cn); People's Post } \\
\text { and Telecom Daily } \\
\text { (http://ermyd.cnii.com.cn/index.htm); } \\
\text { Sohu IT (http://it.sohu.com); China } \\
\text { Comms Network (http://www.cl14.net/); } \\
\text { China Electronic News } \\
\text { (http://www.cena.com.cn); People's Daily } \\
\text { (http://www.people.com.cn) }\end{array}$ \\
\hline Patent & $\begin{array}{l}\text { Publicized patent } \\
\text { quantity }\end{array}$ & $\begin{array}{l}\text { National Bureau of Statistics of China's } \\
\text { website (http://www.stats.gov.cn); State } \\
\text { Intellectual Property Office of P.R.C.'s } \\
\text { website (http://www.sipo.gov.cn) }\end{array}$ \\
\hline
\end{tabular}




\begin{tabular}{|c|c|c|}
\hline Market share & $\begin{array}{l}\text { By product and product } \\
\text { category }\end{array}$ & $\begin{array}{l}\text { China Information Almanacs 2001-2003 } \\
\text { (http://www.cia.org.cn); China } \\
\text { Information Industry Net's Website } \\
\text { (http://www.cnii.com.cn); } \\
\text { Ministry of Information Industry's } \\
\text { Website } \\
\text { (http://www.mii.gov.cn/mii/index.html); } \\
\text { CEO \& CIO China } \\
\text { (http://www.ceocio.com.cn); China } \\
\text { Electronic News } \\
\text { (http://www.cena.com.cn) }\end{array}$ \\
\hline Employment & $\begin{array}{l}\text { Number of engineers and } \\
\text { sales personnel }\end{array}$ & $\begin{array}{l}\text { DTT's website (http://www.datang.com); } \\
\text { GDT's website (http://www.gdt.com.cn); } \\
\text { Huawei's website } \\
\text { (http://www.huawei.com); ZTE's website } \\
\text { (http://www.zte.com.cn); People's Daily } \\
\text { (http://www.people.com.cn) }\end{array}$ \\
\hline $\begin{array}{l}\text { Financial } \\
\text { results }\end{array}$ & $\begin{array}{l}\text { Annual revenue and } \\
\text { profit }\end{array}$ & $\begin{array}{l}\text { DTT's website (http://www.datang.com); } \\
\text { GDT's website (http://www.gdt.com.cn); } \\
\text { Huawei's website } \\
\text { (http://www.huawei.com); ZTE's website } \\
\text { (http://www.Zte.com.cn); Chinese Top } \\
100 \text { Electronics Company List } \\
\text { (http://www.ittop100.gov.cn); Finance } \\
\text { Sina (http://finance.sina.com.cn); } \\
\text { Business Report of Netease } \\
\text { (http://biz.163.com); Ministry of } \\
\text { Information Industry's Website } \\
\text { (http://www.mii.gov.cn/mii/index.html); } \\
\text { Sohu IT (http://it.sohu.com); CEO \& CIO } \\
\text { China (http://www.ceocio.com.cn) }\end{array}$ \\
\hline Values & $\begin{array}{l}\text { Statements about } \\
\text { suppliers' deep held } \\
\text { beliefs }\end{array}$ & $\begin{array}{l}\text { DTT's website (http://www.datang.com); } \\
\text { GDT's website (http://www.gdt.com.cn); } \\
\text { Huawei's website } \\
\text { (http://www.huawei.com); ZTE's website } \\
\text { (http://www.zte.com.cn); CEO \& CIO } \\
\text { China (http://www.ceocio.com.cn); China } \\
\text { Electronics News } \\
\text { (http://www.cena.com.cn) }\end{array}$ \\
\hline
\end{tabular}




\begin{tabular}{|l|l|l|}
\hline Partners & $\begin{array}{l}\text { Companies with which } \\
\text { Chinese suppliers have } \\
\text { partnered }\end{array}$ & $\begin{array}{l}\text { DTT's website (http://www.datang.com); } \\
\text { GDT's website (http://www.gdt.com.cn); } \\
\text { Huawei's website } \\
\text { (http://www.huawei.com); ZTE's website } \\
\text { (http://www.zte.com.cn) }\end{array}$ \\
\hline
\end{tabular}

Table 5 organizes the data sources included in Table 4 into four types: (i) Chinese suppliers' websites, (ii) Established foreign suppliers' websites, (iii) Government websites, and (iv) Online newspapers and journals.

Table 5: Data Sources by Type

\begin{tabular}{|c|c|}
\hline \multicolumn{2}{|l|}{ Chinese Suppliers' Websites } \\
\hline DTT & http://www.datang.com \\
\hline GDT & http://www.gdt.com.cn \\
\hline Huawei & http://www.huawei.com \\
\hline ZTE & http://www.zte.com.cn \\
\hline \multicolumn{2}{|l|}{ Established Foreign Suppliers' Websites } \\
\hline Alcatel & http://www.alcatel.com \\
\hline $\begin{array}{l}\text { Beijing International Switching System Co. } \\
\text { (BISC), a Siemens joint venture }\end{array}$ & http://www.bisc.com.cn \\
\hline Ericsson & http://www.ericsson.com \\
\hline Fujitsu & http://www.fujitsu.com/global \\
\hline Lucent & http://www.lucent.com \\
\hline NEC & http://www.nec.com \\
\hline Nortel & http://www.nortel.com \\
\hline
\end{tabular}




\begin{tabular}{|c|c|}
\hline $\begin{array}{l}\text { Shanghai Bell, an Alcatel (Belgium) joint } \\
\text { venture }\end{array}$ & http://www.alcatel-sbell.com.cn \\
\hline Siemens & http://www.siemens.com \\
\hline \multicolumn{2}{|l|}{ Government Websites } \\
\hline Chinese Top 100 Electronics Company List & http://www.ittop100.gov.cn \\
\hline Ministry of Information Industry & http://www.mii.gov.cn/mii/index.html \\
\hline National Bureau of Statistics of China & http://www.stats.gov.cn \\
\hline $\begin{array}{l}\text { State Intellectual Property Office of the } \\
\text { People's Republic of China }\end{array}$ & http://www.sipo.gov.cn \\
\hline \multicolumn{2}{|l|}{ Online Newspapers and Journals } \\
\hline Business Report of Netease & http://biz.163.com \\
\hline CEO \& CIO China & http://www.ceocio.com.cn \\
\hline China Comms Network & http://www.c114.net \\
\hline China Electronics News & http://www.cena.com.cn \\
\hline China Information Almanacs 2001-2003 & http://www.cia.org.cn \\
\hline China Information Industry Net's Website & http://www.cnii.com.cn \\
\hline Communication Weekly Journal & http://www.comm-weekly.com.cn \\
\hline Finance Sina & http://finance.sina.com.cn \\
\hline People's Daily & http://www.people.com.cn \\
\hline People's Post and Telecommunication Daily & http://ermyd.cnii.com.cn/index.htm \\
\hline Sohu IT & http://it.sohu.com \\
\hline
\end{tabular}




\section{KEY EVENTS OF CHINESE EQUIPMENT SUPPLIERS}

For each of the four Chinese equipment suppliers examined in this research: DTT, GDT, Huawei, and ZTE, (i) this chapter provides an overview, (ii) Appendices A1, B1, C1 and D1 identify, in point form, the key events in their histories, (iii) Appendices A2, B2, C2 and D2 identify the products and technologies these companies developed and (iv) Appendices A3, B3, C3 and D3 provide data on number of employees, revenues and profits.

\subsection{Datang Telecom Technology Co., Ltd. (DTT)}

DTT is a state owned company founded in 1998 by the China Academy of Telecommunications Technology (CATT) and 12 other organizations. DTT took over the assets that belonged to Xi'an Datang.

The CATT is a research institute of the Ministry of Post and Telecommunications ${ }^{1}$ (MPT). In 1993, CATT and the International Telephone and Teledata Inc. (ITTI) ${ }^{2}$, established Xi'an Datang.

Today, DTT is a telecommunication equipment supplier which can provide switching, mobile, optical transmission, wireless, integrated circuits and software products.

\footnotetext{
1 Today the Ministry of Post and Telecommunications is known as the Ministry of Information Industry.

${ }^{2}$ ITTI was a company founded by a group of Chinese scholars in the United States.
} 
DTT's main product was a telephone switching system named SP30. The SP30 was first developed by Xi'an Datang in 1995. The SP30 incorporated the latest integrated circuit technology for the purpose of reducing the volume of the equipment and the power it consumed. The SP30 was upgraded to SP30iEx in 2002. The SP30iEx is a 2.5G integrated service switching platform. OpenSP, DTT's next generation network (NGN), was on trial in Guangdong province by 2003 (Liu, 2003).

DTT is the Chinese company mostly involved in the development of the $3 \mathrm{G}$ wireless standard TD-SCDMA. The standard was proposed to the International Telecommunications Union - Telecoms (ITUT) in 2000 (China Comms Network, 2003). DTT's TD-SCDMA was accepted as a 3G standard together with the CDMA2000 and WCDMA standards. As of 2003, The Ministry of Information Industry was still testing the TD-SCDMA standard.

DTT and Siemens partnered to develop the TD-SCDMA standard. However, in 2003 Siemens signed a cooperation contract with Huawei for the R\&D of the TD-SCDMA (Dong, 2003).

In 1996, Xi'an Datang, the predecessor to DTT, was ranked 84 in the Chinese Top 100 Electronics Companies List (Appendix E). DTT was ranked amongst the top 100 Chinese companies from 1998 to 2002 . In 2002 it was ranked $40^{\text {th }}$. 
By the end of 2003, DDT had 3,482 staff members. DTT declared a deficit of $\$ 180$ million RMB in its 2003 financial report. DTT disappeared from the Chinese Top 100 Electronics Companies List in 2003.

Figure 4 illustrates DTT's revenues from 1998 to 2003.

Figure 4: DTT's Annual Revenues and Net Profits from 1998 to 2003

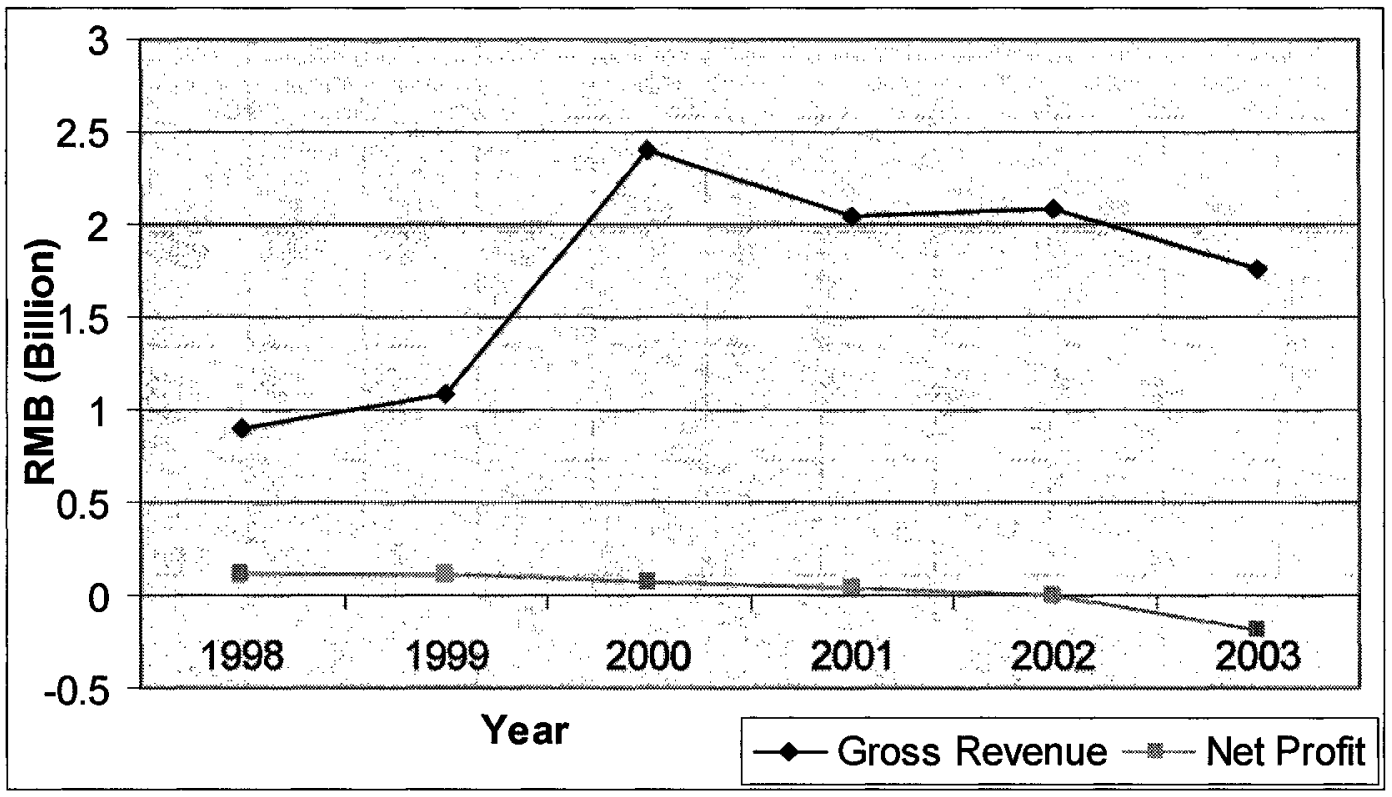

Source: DDT annual reports from 1998 to 2003.

\subsection{Great Dragon Information Technology Co., Ltd. (GDT)}

GDT was founded in March 1995 in Beijing by the People's Liberation Army (PLA) Information Engineering Academy and eight other telecommunication equipment factories (Gao, 2002). GDT is a state owned company. 
GDT's predecessor was the 04 Group. The 04 Group was a loose organization that cooperated to sell HJD04 switches. HJD04 was China's first large capacity Stored Program Controlled (SPC) telephone switching system. It could process 10,000 subscriber lines. The development of the first high capacity switch was deemed to be a major break-through achievement for the Chinese telecommunication industry.

The PLA Information Engineering Academy owns the HJD04 technologies. It authorized telephone equipment factories in Beijing, Luoyang and Changchun to manufacture the HJD04 switch. Each of these factories had its own sales and service groups (Xiao, 2003). The first HJD04 trial exchange was undertaken in Wuzhi county, Henan Province in 1992. The next year, HJD04 was deployed in Changchun city, Jilin Province.

The first production line of HJD04 was established in Luoyang city, Henan Province, in 1994. The manufacture of HJD04 put an end to foreign companies' high profit margins (Yao, 2002) and allowed Chinese suppliers to export SPC switches.

The HJD04 was exported to North Korea in 1994. This was the first export contract for a Chinese telecommunication equipment supplier (GDT, 2003).

The HJD04 SPC exchange switch received the "first-place national scientific and technological progress award" issued by the State Council of the People's Republic of 
China in 1996 and the Industrial and Commercial Bank of China offered GDT a buyer's credit and a loan of $\$ 500$ million RMB (GDT, 2003).

GDT developed the first Chinese large capacity intelligent network, HJD04CIN, in 1997.

GDT participated in the Cuban Youth Island Telecommunication Project and signed a contract for $\$ 300$ million USD with Cuba in 1998 . The project was supported by the central government in Beijing and the Ministry of Commerce (GDT, 2003).

GDT signed a cooperation project with Colombia in 1999. In 2000, GDT successfully developed the HJD04E switch and deployed the GDC/GS2000 GSM switching system in Yan'an, Shaanxi Province.

In 2000, GDT was awarded the ISO9001 certificate for manufacturing.

In 2001, GDT developed the OpenIP system, an intelligent network system which can be used in Internet protocol networks and the high-end core router OmniRouter880.

From 1995 to 1998 , GDT grew rapidly due to the success of the HJD04 series of switches. GDT invested $\$ 20$ million RMB in advertisements, and was thought of as the leader of the four Chinese suppliers. GDT ranked $28^{\text {th }}$ and $54^{\text {th }}$ in the Chinese Top 100 Electronics Company List, in 1998 and 1999. The fierce competition in the SPC market began in 1999 (Zhu \& Pan, 2001). GDT was not ranked in the Chinese Top 
100 Electronics Company List after 1999. Tang (2003) argues that an important reason for GDT's lack of growth after 1999 was that the company lacked advanced technologies other than those incorporated in the HJD04 series.

GDT was reorganized three times, in 1996, 1999 and 2002. After the second reorganization, the China Putian Corporation, a Chinese provider of information technology products and services, became the largest shareholder of GDT. The China Putian Corporation is a corporation owned by the state owned Assets Supervision and Administration Commission of the State Council.

\subsection{Huawei Technologies (Huawei)}

Mr. Ren Zhengfei, a former officer in China's People's Liberation Army, founded the Huawei company in Shenzhen in 1988. Huawei is the only private company among the four Chinese suppliers included in this study.

Today, Huawei is a worldwide company that develops and sells switching products, SDH/DWDM transmission, optical access, mobile and wireless products, ATM, intelligent networks, support networks, power supply and environment monitoring, videoconferencing and CATV equipment.

Huawei has 50 branch offices worldwide and research institutes in Dallas, Bangalore, Moscow, Stockholm, Beijing and Shanghai. 
Huawei's products have been deployed in over 40 countries, including Germany, Spain, Russia, Brazil, Thailand, Singapore, Egypt and South Korea (Huawei, 2003a).

In the early years, Huawei was an agent that sold a private branch exchange named HAX on behalf of a company located in Hong Kong. In 1991, Huawei decided to develop its own SPC switch. In 1994, Huawei released the low capacity SPC exchange C\&C08A and ETS-450, a wireless communication system to address the needs of Chinese rural areas.

In 1995, Huawei released the $C \& C 08 C$, a large capacity SPC switch and established a research institute in Beijing to develop mobile and data technologies.

In 1996, Huawei's research institute in Beijing, developed a Signal Transfer Point (STP) product and its access router named Quidway2501. At that time the Chinese STP market was dominated by Shanghai Bell (Alcatel) and Nortel. STP is part of SS7. This requires high stability and high performance to support the telephone network's requirements for high reliability and high access speed.

Huawei was successful in the STP market. By 1996, all Chinese provinces had deployed Huawei's STP equipment. Huawei's STP products became part of the national backbone network in 1997. Huawei and Shanghai Bell, an Alcatel (Belgium) joint venture, won the national STP contract for China Mobile in 1997 (Cheng \& Liu, 2003). 
"Huawei Basic Rules" were publicized in the company's internal newspaper on December 26, 1996. The rules emphasized that the company's product development must depend on systems and processes but not on people. Also in 1996, Huawei's C\&C08 switches were exported to Hong Kong.

In 1997, Mr. Ren Zhengfei, visited IBM, Hughes, Bell Labs and HP to meet their top management teams personally.

In 1998, Huawei started a large scale recruitment plan and fought with ZTE for the new graduates of prestigious Chinese universities. In the same year, Huawei became the number one supplier of telecommunications equipment in China. In 1998, Huawei's annual sales exceeded those of Shanghai Bell and BISC.

In 1999, Huawei reformed its internal processes with the help of IBM, HayGroup, PriceWaterhouseCoopers and FraunhoferGesellschaft. It also deployed the Software Engineering Institute's Capability Maturity Model for software development.

In 2001, Huawei sold its Avansys Power Electric Co. to Emerson Electric Co. for $\$ 750$ million USD. Also in 2001, Huawei released the high end core Gigabit Switch Router Quidway NetEngine80 to the Chinese market and recruited 5,000 new graduates. Eighty percent of the new graduates recruited were assigned to R\&D activities. 
In 2002, Huawei founded a subsidiary company in Texas named Futurewei for the purpose of developing the North American market.

In 2003, Huawei established joint-ventures with $3 \mathrm{Com}$ to develop routers, with Siemens to develop the TD-SCDMA standard, and with Infineon Technologies to develop the low cost R\&D platform for WCDMA mobile phones.

Huawei’s overseas market grew steadily. In 2003 its overseas sales totaled $\$ 1.05$ billion USD, an increase of $90 \%$ from the previous year (Hauwei, 2003b).

By the end of 2003, Huawei had 22,000 employees. Of the 22,000 employees, 1,500 held doctorates' and 8,000 held masters' degrees.

Figure 5 illustrates Huawei's annual revenues from 1992 to 2003. 
Figure 5: Huawei's Annual Revenues from 1992 to 2003

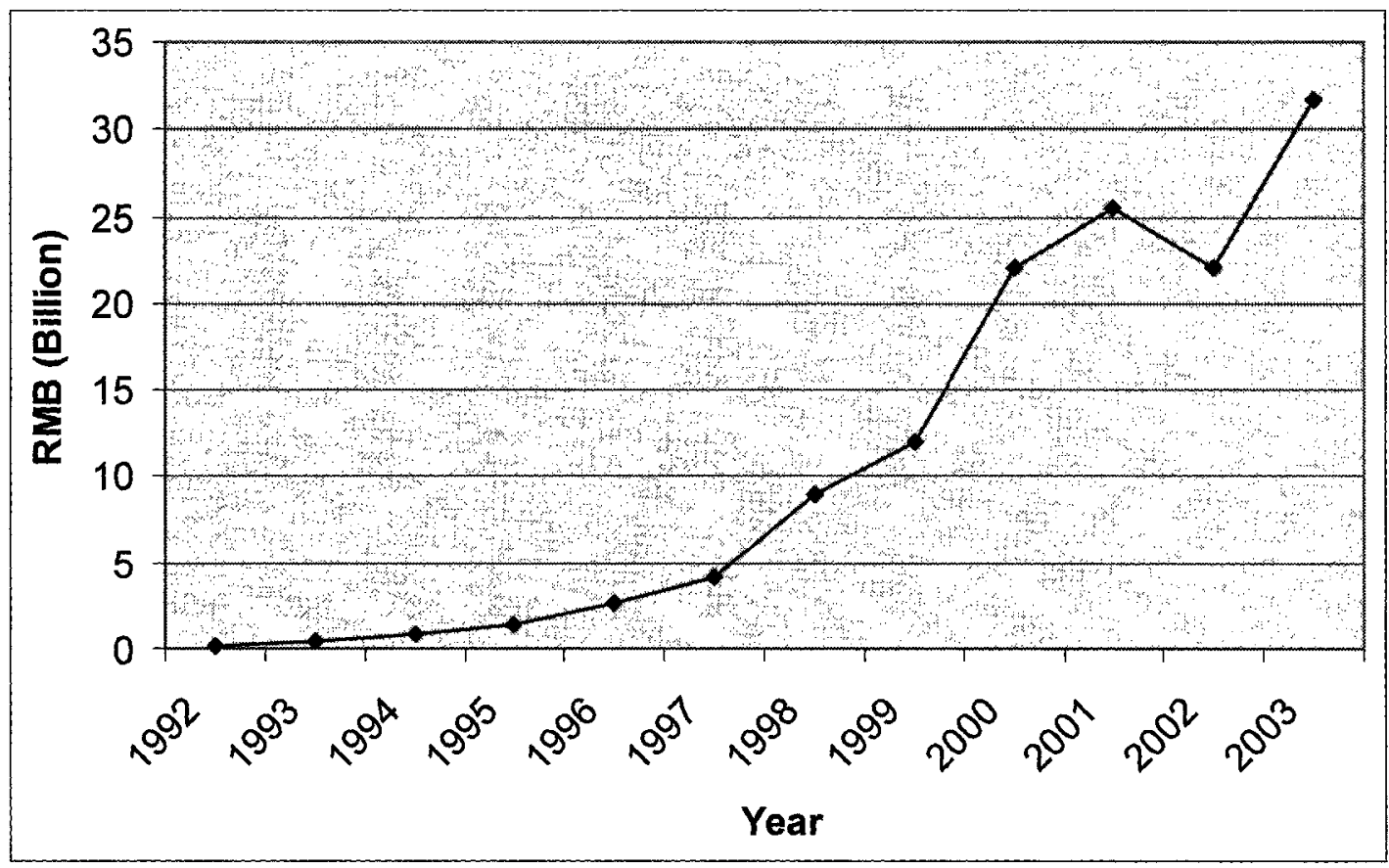

Source: Appendix C3

\subsection{Zhongxing Telecommunication Equipment Co., Ltd (ZTE)}

ZTE was founded as a state owned company in Shenzhen in 1985.

ZTE first produced electronic watches, electronic pianos and the small capacity switch exchange ZX60. The capacity of the ZX60 was 68 subscriber lines. Today ZTE is an important global supplier of telecommunications equipment with products deployed in over 40 countries and regions including Cyprus, Bangladesh, Myanmar, Thailand, Russia, Egypt, Kenya, Congo, Zambia and Hong Kong. ZTE's product portfolio includes switches, access networks, optical transmission equipment, NGN, CDMA and GSM systems, and mobile terminals for CDMA, GSM and PHS. 
In 1990, ZTE developed its first low capacity SPC switch, a private branch exchange named ZX500. It had multiple standard trunk interfaces, and better performance than other private branch exchanges. ZTE marketed the ZX500 to the Chinese rural market. In 1994, ZTE released its ZXJ2000 SPC exchange switch. The ZXJ2000 SPC could be upgraded to become a large capacity exchange switch and met Chinese requirements for Signaling System No.7 (SS7). In 1995, ZTE released its large capacity SPC ZXJ10 and marketed it to Chinese urban areas (ZTE, 2003).

ZTE established research institutes in Nanjing and Shanghai to develop large capacity SPC exchange and access network equipment in 1993 and 1994 respectively.

In 1996, ZTE announced that it had three strategic priorities: (i) Develop from being a single switching product company to a multiple product company; (ii) address the needs of the urban market as well as those of the rural market; and (iii) address the needs of international markets.

During the Shanghai International Telecommunication Equipment Exhibition of 1996, ZTE unveiled various products including the ZXJ10 switch, access network equipment, optical transmission, video conference system and power supply system.

In 1998, ZTE established a research institute in New Jersey to track the latest technologies including Softswitch. Also in 1998, ZTE exported a ZXJIO turn-key 
project to Pakistan, which was ZTE's first export contract won by a Chinese equipment supplier in an open competition.

In 2001, ZTE's revenue from mobile products exceeded revenues from switching and access product.

By the end of 2003, ZTE had 16,609 staff, 13 wholly owned R\&D centers worldwide and research partnerships with large, well established companies such as Texas Instruments, Motorola and Agere Systems (ZTE's annual report of 2003).

Figure 6 illustrates ZTE's annual revenues and profits from 1996 to 2003. 
Figure 6: ZTE's Annual Revenue and Profits from 1996 to 2003

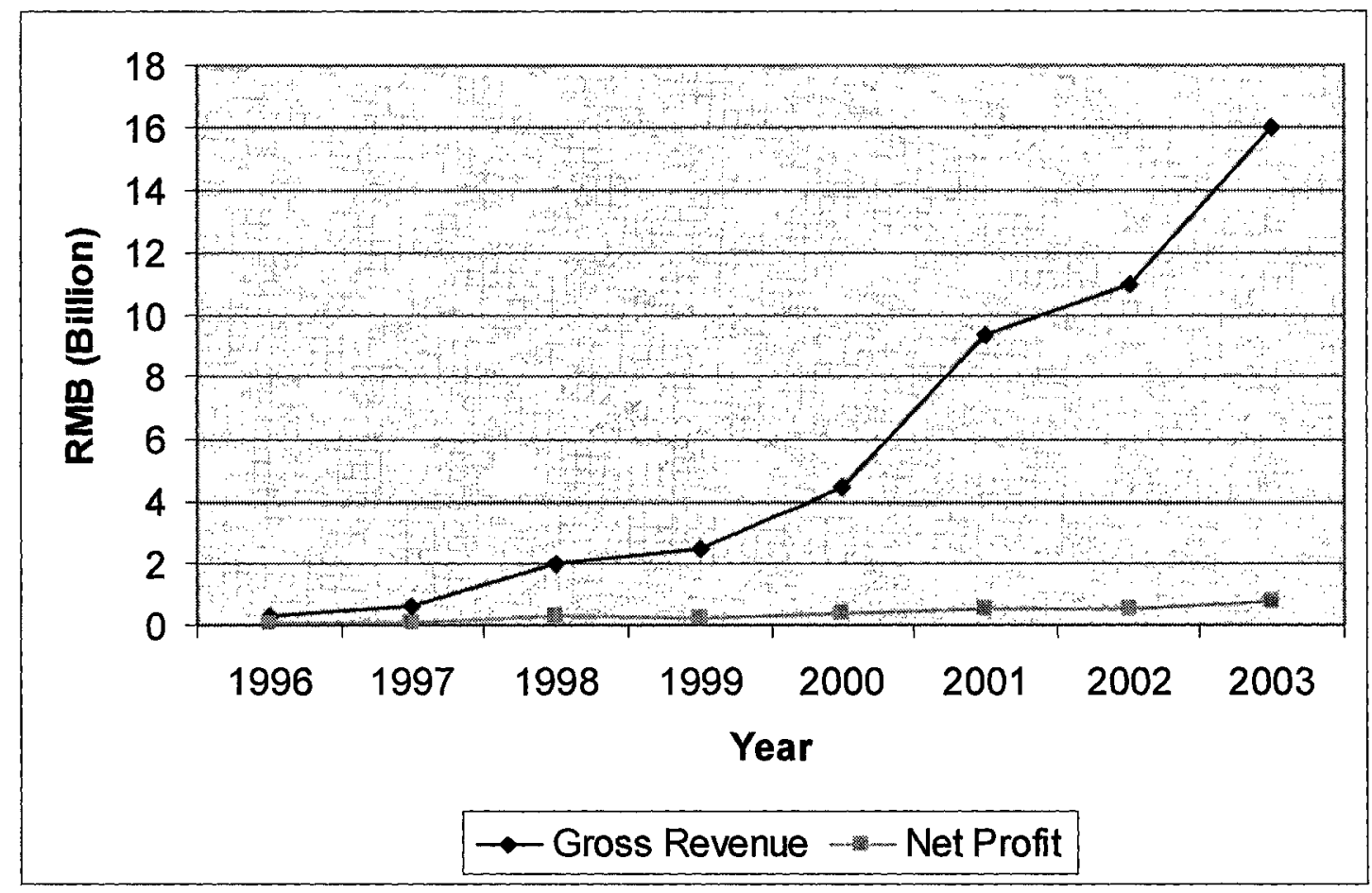

Source: ZTE annual reports from 1996-2003. 


\section{COMPARING CHINESE AND ESTABLISHED EQUIPMENT SUPPLIERS}

Chapter 5 is organized into three sections. Section 5.1 identifies the competitive regimes observed from 1985 to 2003 . Section 5.2 compares Chinese and foreign suppliers during the competitive isolation regime observed from 1985 to 1994. Section 5.3 compares the competitive convergence regime observed from 1995 to 2003.

Each section starts with a table that compares the salient characteristics of Chinese and established foreign suppliers based on the constructs of two theoretical perspectives, technology disruption and capabilities. Then the competitive regime is described from the disruptive technology perspective. The discussion is anchored around the three constructs emphasized by the disruptive technology perspective: (i) the market, (ii) the product that drives technological advances, and (iii) the factors that drive demand.

Then the section compares Chinese and foreign suppliers using six components of the capabilities perspective: (i) technology, (ii) brand, (iii) sales personnel, (iv) product development, (v) manufacturing, and (vi) priorities. The first three components focus on suppliers' resources. Components (iv) and (v) focus on suppliers' processes, and (vi) focuses on suppliers' values. 


\subsection{Competitive Regimes Identified}

The overview in chapter 4 and Appendices A, B, C and D were examined to identify competitive regimes (Adner, 2002). The competitive regimes identified were used to organize the comparison between Chinese and foreign suppliers.

The existence of two competitive regimes was observed: a competitive isolation regime and a competitive convergence regime. Clear evidence of the existence of a competitive disruption regime was not observed.

For the purpose of this research, the competitive isolation regime started with the foundation of the first Chinese telecommunications supplier in February of 1985 and ended in 1994, the year the 04 Group (GDT's predecessor) (i) established the first facility for manufacturing high capacity SPC switches in China and (ii) exported its first high capacity switch. During this regime, technologies held by Chinese and foreign suppliers did not interact in the course of their evolution.

The competitive convergence regime started in 1995 and continues today. The Chinese suppliers' introduction of high capacity SPC switches in 1995 for sale into Chinese urban and rural markets as well as foreign markets marks the start of the competitive convergence regime. Chinese and foreign suppliers competed head to head for the urban and rural Chinese market and then in the global market. By the end of 2003, two Chinese suppliers, ZTE and Huawei, sold greater numbers of subscriber lines in China than foreign suppliers did. Moreover, top executives of established 
suppliers were becoming concerned about the fierce competition from Chinese suppliers in the global markets. For the purpose of this research, the competitive convergence regime ended in December 2003, the last month for which data was collected. In a competitive convergence regime, technologies evolve to compete head-on for the same customers.

There is no evidence that a competitive disruption regime has started in the context of the switching market and this research. In a competitive disruption regime, one technology cedes dominance of its market to its rival technology.

Appendices F and $\mathrm{G}$ illustrate the growth in telecommunications in China. Appendix F shows the significant growth in the number of subscribers to fixed, mobile and Internet services in China from 1991 to 2003. Appendix G illustrates the investment made by the MII of China from 1994 to 2003.

\subsection{Competitive Isolation: 1985 to 1994}

Table 6 uses the constructs of two theoretical perspectives to compare the Chinese and foreign telecommunications equipment suppliers from 1985 to 1994. 
Table 6: The 1985-1994 Competitive Isolation Regime

\begin{tabular}{|c|c|c|c|}
\hline \multirow{2}{*}{$\begin{array}{l}\text { Theoretical } \\
\text { perspective }\end{array}$} & \multirow{2}{*}{$\begin{array}{l}\text { Construct } \\
\text { emphasized }\end{array}$} & Chinese Suppliers & Foreign Suppliers \\
\hline & & $\begin{array}{l}\text { Huawei, ZTE and } 04 \\
\text { Group }\end{array}$ & $\begin{array}{l}\text { Alcatel Bell (Belgium) sold } \\
\text { its products through } \\
\text { Shanghai Bell, a joint } \\
\text { venture established in } \\
\text { 1984; Siemens first sold its } \\
\text { products directly and then } \\
\text { through BISC, a joint } \\
\text { venture established in } \\
\text { 1990; NEC first sold its } \\
\text { products directly and then } \\
\text { through TNTE, a joint } \\
\text { venture established in } \\
\text { 1989; Ericsson first sold } \\
\text { its products directly and } \\
\text { then through ENC, a joint } \\
\text { venture established in } \\
\text { 1992; Lucent first sold its } \\
\text { products directly and then } \\
\text { through Lucent Qingdao, a } \\
\text { joint venture established in } \\
\text { 1993; Alcatel (France), } \\
\text { Fujitsu, and Nortel sold } \\
\text { their products directly. }\end{array}$ \\
\hline \multirow[t]{2}{*}{$\begin{array}{l}\text { Disruptive } \\
\text { technology }\end{array}$} & Market & $\begin{array}{l}\text { Post and } \\
\text { Telecommunications } \\
\text { Bureaus servicing } \\
\text { consumers in rural Chinese } \\
\text { areas }\end{array}$ & $\begin{array}{l}\text { Post and } \\
\text { Telecommunications } \\
\text { Bureaus servicing } \\
\text { consumers in large Chinese } \\
\text { cities }\end{array}$ \\
\hline & $\begin{array}{l}\text { Products driving } \\
\text { technological } \\
\text { advances }\end{array}$ & $\begin{array}{l}\text { Low capacity SPC } \\
\text { exchange switches } \\
\text { designed to satisfy rural } \\
\text { customers' demands }\end{array}$ & $\begin{array}{l}\text { Large capacity digital SPC } \\
\text { exchange switches } \\
\text { designed to satisfy the } \\
\text { requirements of large } \\
\text { service providers in North } \\
\text { America, Europe and Japan } \\
\text { which were subsequently } \\
\text { modified to satisfy the } \\
\text { requirements of Chinese } \\
\text { cities }\end{array}$ \\
\hline
\end{tabular}




\begin{tabular}{|c|c|c|c|}
\hline & $\begin{array}{l}\text { Factors driving } \\
\text { demand }\end{array}$ & $\begin{array}{l}\text { Service providers required } \\
\text { cheap, low power, easy to } \\
\text { operate switches with basic } \\
\text { functions and Chinese } \\
\text { interfaces that did not } \\
\text { require educated } \\
\text { professionals to operate } \\
\text { them } \\
\text { Consumers in rural areas } \\
\text { required very cheap, plain } \\
\text { old telephone service } \\
\text { US } \$ 80 \text { for PSTN line in } \\
1990 \text { (Yu, 1999) }\end{array}$ & $\begin{array}{l}\text { Service providers required } \\
\text { high capacity switches with } \\
\text { stable performance for } \\
\text { voice and data } \\
\text { communication; each } \\
\text { exchanges in a city was } \\
\text { required to be a Service } \\
\text { Switching Point (SSP); } \\
\text { tandem exchanges in cities } \\
\text { were required to be high } \\
\text { capacity and stable } \\
\text { Consumers in urban areas } \\
\text { required very cheap, plain } \\
\text { old telephone service }\end{array}$ \\
\hline & & & $\begin{array}{l}\text { US } \$ 300-\$ 500 \text { for PSTN } \\
\text { line in } 1990 \text {; US } \$ 100 \text { for } \\
\text { PBX in } 1994 \text { (Zhong, } \\
2002 \text {; Cheng \& Liu, 2003) }\end{array}$ \\
\hline \multirow[t]{3}{*}{ Capabilities } & Technology & $\begin{array}{l}\text { Multi-standards trunk } \\
\text { interfaces; anti-thunder } \\
\text { design; low power } \\
\text { consumption }\end{array}$ & $\begin{array}{l}\text { Large capacity and } \\
\text { stability; remote module } \\
\text { racks functioned locally } \\
\text { when the connecting cable } \\
\text { to main office broke }\end{array}$ \\
\hline & Brand & $\begin{array}{l}\text { Not in the "Chinese Top } \\
100 \text { Electronics Company } \\
\text { List" (Appendix E); } \\
\text { Chinese suppliers unknown } \\
\text { in Chinese cities and } \\
\text { foreign countries }\end{array}$ & $\begin{array}{l}\text { For } 1992,1993 \text { and } 1994, \\
\text { Shanghai Bell ranked 5, } 6 \\
\text { and } 2 \text { and BISC ranked 73, } \\
19 \text { and } 14 \text { in the "Chinese } \\
\text { Top } 100 \text { Electronics } \\
\text { Company List" (Appendix } \\
\text { E); established suppliers } \\
\text { well known in Chinese } \\
\text { cities and outside of China }\end{array}$ \\
\hline & Sales personnel & $\begin{array}{l}\text { Large number of sales } \\
\text { personnel proactively } \\
\text { searching for customers in } \\
\text { rural areas (Zhong, 2002; } \\
\text { Cheng \& Liu, 2003) }\end{array}$ & $\begin{array}{l}\text { Small number of sales } \\
\text { personnel taking orders } \\
\text { from urban customers who } \\
\text { were eager to sign service } \\
\text { contracts (Zhong, 2002) }\end{array}$ \\
\hline
\end{tabular}




\begin{tabular}{|l|l|l|l|}
\hline & $\begin{array}{l}\text { Product } \\
\text { development }\end{array}$ & $\begin{array}{l}\text { Designed and developed } \\
\text { products to meet the needs } \\
\text { of Chinese rural customers }\end{array}$ & $\begin{array}{l}\text { Modified mature products } \\
\text { to work in Chinese cities }\end{array}$ \\
\cline { 2 - 4 } & Manufacturing & $\begin{array}{l}\text { No experience in high } \\
\text { capacity SPC switches }\end{array}$ & $\begin{array}{l}\text { Years of experience in high } \\
\text { capacity SPC switches }\end{array}$ \\
\cline { 2 - 4 } & Priorities & $\begin{array}{l}\text { Pay for the R\&D leading to } \\
\text { the development and } \\
\text { manufacture of high } \\
\text { capacity SPC }\end{array}$ & $\begin{array}{l}\text { High profit margins from } \\
\text { equipment sales }\end{array}$ \\
\hline
\end{tabular}

Source: (Cheng \& Liu, 2003; Du \& Wang, 1997; Xin \& Liu, 1998; Yu, 1999; Zhong, 2002)

\subsubsection{Disruptive Technology Perspective}

From 1985 to 1994 , Chinese suppliers operated in isolation from established foreign suppliers. Chinese suppliers aimed to satisfy the needs of Chinese rural areas, a market largely ignored by the established suppliers. There were three main reasons for the isolation. First, Chinese suppliers sold low capacity SPC switches to satisfy the needs of rural Chinese areas while foreign suppliers sold high capacity SPC switches to satisfy the needs of large and prosperous Chinese cities. Because of their poor reliability, the Chinese suppliers' low capacity switches could not be used in the urban market that existed at the time. Chinese suppliers targeted the nonconsumer market that existed in rural areas. To the rural market, Chinese suppliers added value.

Chinese suppliers introduced SPC switches with capacities that ranged from 68 to 2,500 lines years after established foreign suppliers introduced SPC switches with capacities that ranged from 100,000 to 240,000 lines. To the established foreign 
suppliers, the development of small capacity switches to meet the needs of rural areas was viewed as an unattractive opportunity.

The third reason for the isolation between Chinese suppliers and established suppliers was that the requirements of the Post and Telecommunications Bureaus (PTBs) in rural areas were quite different than the requirements of the PTBs in the cities. PTBs in rural areas required cheap, low power, easy to operate switches with basic functions and Chinese interfaces that did not depend on educated professionals to operate them. In contrast, PTBs in urban areas required high capacity, stable performance switches that could also act as Service Switching Points (SSPs).

\section{Market}

From 1985 to 1994 , Huawei and ZTE focused on satisfying the requirements of consumers and PTBs in rural areas. During this period, most Chinese who lived in rural areas were non-consumers of telephone services. Foreign suppliers had ignored them.

Foreign suppliers focused on satisfying the needs of high-income consumers in large Chinese cities. Foreign suppliers, either directly or through joint ventures with Chinese organizations, sold modified versions of their existing high capacity switches to PTBs in urban areas. These high capacity switches had been designed initially to meet the needs of the largest service providers in North America, Japan, and Western Europe. 
Table 7 provides information on the suppliers' first SPC deployments in China by year. The information includes the year the SPC deployment started, the company name, the SPC switch name, and the market in which the switch was deployed.

Table 7: Suppliers' First Deployments of SPC Switches in China

\begin{tabular}{|c|c|c|c|}
\hline $\begin{array}{c}\text { Year of } \\
\text { deployment }\end{array}$ & Company & Switch & Market switch was deployed \\
\hline 1980 & Fujitsu & F-150 & Fuzhou city, capital of Fujian Province \\
\hline 1983 & $\begin{array}{l}\text { Nortel } \\
\text { Networks }\end{array}$ & DMS & $\begin{array}{l}\text { Guangzhou city, capital of Guangdong } \\
\text { Province }\end{array}$ \\
\hline 1984 & Ericsson & AXE10 & Beijing, China's capital \\
\hline 1985 & AT\&T & 5ESS & Beijing, China's capital \\
\hline 1985 & $\begin{array}{l}\text { Shanghai } \\
\text { Bell }\end{array}$ & S1240 & Hefei, capital of Anhui Province \\
\hline 1985 & Siemens & EWSD & Changsha, capital of Hunan Province \\
\hline 1987 & \multirow{3}{*}{ ZTE } & ZX60 & C5 terminal switching centre in rural area \\
\hline 1991 & & $\mathrm{ZX} 500 \mathrm{~A}$ & $\begin{array}{l}\text { C5 terminal switching centre in Taoyuan, a } \\
\text { town in Wujiang county, Jiangsu Province }\end{array}$ \\
\hline 1993 & & ZXJ2000 & C5 terminal switching centre in rural area \\
\hline 1992 & 04 Group & HJD04 & $\begin{array}{l}\text { C5 terminal switching centre in Wuzhi } \\
\text { county, Henan Province }\end{array}$ \\
\hline 1992 & \multirow[b]{2}{*}{ Huawei } & JK1000 & C5 terminal switching centre in rural area \\
\hline 1994 & & $\mathrm{C} \& \mathrm{C} 08 \mathrm{~A}$ & $\begin{array}{l}\text { C5 terminal switching centre in Yiwu county, } \\
\text { Zhejiang Province }\end{array}$ \\
\hline
\end{tabular}

Source: (Companies' websites; Du \& Wang, 1997)

The information in Table 7 shows that established foreign suppliers deployed their first switches in Chinese cities that were provincial capitals and in Beijing, China's 
capital, while Chinese suppliers deployed their first switches in rural counties. This information also shows that established suppliers provided equipment to service Chinese cities years before ZTE and Huawei were founded ${ }^{3}$.

In $1995,90 \%$ of Huawei's products and $100 \%$ of ZTE's products were sold to county switching centers (level 4) and terminal switching centers (level 5). In contrast, 90\% of Shanghai Bell's products were sold to great district centers (level 1), provincial switching centers (level 2), and city switching centers (level 3) ${ }^{4}$ (Du \& Wang, 1997).

In 1995 , Chinese suppliers accounted for $22 \%$ of sales of telecommunications equipment in China, established foreign suppliers and their joint ventures accounted for $78 \%$ (Du \& Wang, 1997).

\section{Product}

Table 8 identifies the SPC switches introduced by foreign and Chinese suppliers from 1975 to 1995 . Table 8 provides information on the year the SPC switch was introduced, the company manufacturing the switch, the name and capacity of the switches, and the markets were the switches were deployed.

\section{Table 8: Introduction of SPC Switches}

\footnotetext{
${ }^{3}$ ZTE and Huawei were founded in 1985 and 1988 respectively.

${ }^{4}$ There are five levels of switching centers in China; $\mathrm{C1}$ : Great District Switching Center; C2: Province Switching Center; C3: District (City) Switching Center; C4: County Switching Center; and C5: Terminal Switching Center.
} 


\begin{tabular}{|c|c|c|c|c|}
\hline $\begin{array}{c}\text { Year of } \\
\text { introduction }\end{array}$ & Company & Switch & $\begin{array}{l}\text { Capacity } \\
\text { (Number of } \\
\text { subscriber lines) }\end{array}$ & $\begin{array}{l}\text { Locations of first } \\
\text { deployments }\end{array}$ \\
\hline 1975 & Ericsson & AXE10 & $\begin{array}{l}\text { More than } \\
10,000\end{array}$ & Cities in Finland \\
\hline 1979 & Nortel & DMS100 & 100,000 & Cities in North America \\
\hline Before 1980 & Fujitsu & F-150 & 240,000 & Cities in Japan \\
\hline 1980 & Siemens & EWSD & $\begin{array}{l}\text { More than } \\
10,000\end{array}$ & Cities in Germany \\
\hline 1980 & Alcatel & E10B & $\begin{array}{l}\text { More than } \\
10,000\end{array}$ & Cities in France \\
\hline 1981 & $\begin{array}{l}\text { Bell } \\
\text { (Belgium) }\end{array}$ & $\mathrm{S} 12$ & 200,000 & $\begin{array}{l}\text { Cities in Belgium and } \\
\text { Germany }\end{array}$ \\
\hline 1987 & ZTE & ZX60 & 68 & $\begin{array}{l}\text { C5 terminal switching } \\
\text { centre in rural China }\end{array}$ \\
\hline 1991 & ZTE & ZX500A & 500 & $\begin{array}{l}\text { C5 terminal switching } \\
\text { centre in Taoyuan, a } \\
\text { town in Wujiang county, } \\
\text { Jiangsu Province, China }\end{array}$ \\
\hline 1992 & Huawei & JK1000 & 1,000 & $\begin{array}{l}\text { C5 terminal switching } \\
\text { centre in rural China }\end{array}$ \\
\hline 1992 & 04 Group & HJD04 & 10,000 & $\begin{array}{l}\text { C5 terminal switching } \\
\text { centre in Wuzhi county, } \\
\text { Henan Province, China }\end{array}$ \\
\hline 1993 & ZTE & ZXJ2000 & 2,500 & $\begin{array}{l}\text { C5 terminal switching } \\
\text { centre in rural China }\end{array}$ \\
\hline 1994 & Huawei & $\mathrm{C} \& \mathrm{C} 08 \mathrm{~A}$ & 2,000 & $\begin{array}{l}\text { C5 terminal switching } \\
\text { centre in Yiwu county, } \\
\text { Zhejiang Province, China }\end{array}$ \\
\hline
\end{tabular}

Source: Companies' websites 
Huawei's and ZTE's technological advances were driven by SPC exchange switches they designed specifically to satisfy the needs of consumers and PTBs in rural areas. ZTE's ZX60, ZX500, ZX500A, ZXJ2000, ZXJ2000A, and Huawei's JK1000 and C\&C08A SPC switches were low capacity switches. They were deployed to serve the needs of the rural market.

The first Chinese high capacity SPC exchange switch was the HJD04 ${ }^{5}$. The HJD04 was deployed by the 04 Group to serve the needs of consumers in Wuzhi county, Henan, in 1992.

All of the foreign companies' SPC switches could handle more than 10,000 subscriber lines before they were deployed into the Chinese market. However, from 1985 to 1994 , Huawei, and ZTE struggled to develop low capacity SPC switches (Xin \& Liu, 1998; Cheng \& Liu, 2003).

Foreign suppliers' remote module racks could function as low capacity SPC exchanges.

Thus, the low capacity SPC exchanges offered by Chinese suppliers were unattractive to Post and Telecommunications Bureaus servicing large cities. To these Post and Telecommunications Bureaus, the performance of the exchange switches manufactured by Chinese suppliers was below their minimum performance thresholds.

\footnotetext{
${ }^{5}$ In China, a SPC switch with a capacity to serve 10,000 or more subscriber lines was deemed to be a high capacity switch.
} 


\section{Factors driving demand}

China Post and Telecom was the only service provider of fixed services in China until 1998. China Post and Telecom controlled the planning of all the PTBs in China,. However, PTBs in cities and counties had right to decide which telecommunication equipment to purchase based on their own needs and ability to pay ${ }^{6}$. PTBs in cities needed high capacity SPC exchanges to service the needs of high density populations. Switch stability and reliability were very important to them. Tandem exchanges installed in cities also required stability, reliability and high capacity.

In addition to the requirement for stability and reliability, starting 1990, the Ministry of Information Industry required all the PTBs in the cities deploy SPC switches that could also act as Service Switching Points (SSPs).

Typically, an urban family had to wait six months and pay US\$ 500 to install a telephone line in the early 1990's (Zhong, 2002; Cheng \& Liu, 2003). Foreign companies sold their products in Chinese cities at high price seeking large profit margins. The price of plain old telephone service in the city was in the US\$300 US\$500 per line in 1990 and US\$100 per line for PBX in 1994.

\footnotetext{
${ }^{6}$ After January 2000, only PTBs in Chinese cities could make their own decisions. PTBs in counties lost this kind of power (Sun, 2002).
} 
PTBs in Chinese rural areas were poor. They did not have much electrical power and operated different generations of telecommunication systems. Equipment maintenance was difficult. The cost of maintenance for outdoor cables and construction fees were much higher than the costs in urban areas (Cheng \& Liu, 2003). PTBs in Chinese rural areas could not pay for the high capacity SPC switches being sold by the established suppliers or their joint ventures. These PTBs needed cheap switches to provide plain voice communication service.

Chinese consumers in both urban and rural areas wanted cheap plain, old telephone service. Capacity to pay for the service was much greater for consumers in urban areas than in rural areas. From 1988 to 1995 , yearly income per person living in Chinese cities was 2.0 to 2.6 times higher than the yearly income per person living in rural $\operatorname{areas}^{7}$ (National Bureau of Statistics of China, 1996).

High-income Chinese consumers in urban areas were willing to pay for the services offered by high capacity exchange switches manufactured by foreign suppliers. But most rural consumers could not afford to pay the high prices paid by city consumers. Consumers in rural areas were prepared to pay low prices for services provided by the unreliable low capacity exchange switches manufactured by Chinese suppliers.

7 Yearly income per person living in Chinese cities was 1119.4, 1260.7, 1387.3, 1544.3, 1826.1, 2336.5, 3179.2 and 3892.9 Renminbi (RMB) in 1988, 1989, 1990, 1991, 1992, 1993, 1994, and 1995 respectively. For these same years, yearly income per person living in rural areas was 544.9, 601.5, 686.3, 708.6, 784.0, 921.6, 1,221.0 and 1,577.7 RMBs (National Bureau of Statistics of China, 1996). 


\subsubsection{Capabilities Perspective}

\section{Technology}

Huawei and ZTE had technology to develop low capacity SPC exchanges. Their capacity ranged from 68 to 2,500 subscriber lines. The 04 Group developed the first Chinese high capacity switch, the HJD04, in 1992. The HJD04's capacity was 10,000 subscriber lines.

Chinese suppliers' SPC switches were designed to require less electrical power than foreign companies' switches (Zhong, 2002). Their products had trunk interfaces that supported multiple standards, incorporated anti-thunder designs and used Chinese interface for the operation menus (Cheng \& Liu, 2003).

The ETS450, Huawei's wireless communication system based on C\&C08, was used to connect extremely dispersed subscribers in mountain areas (Cheng \& Liu, 2003). This avoided laying trunks and lines for only few subscribers, reducing construction and maintenance costs.

Foreign companies had high capacity SPC exchanges. Their remote module racks could function as low capacity SPC exchanges. 


\section{Brand}

Established foreign suppliers all had strong global brands. Their joint ventures operating in China were well known in the Chinese urban areas they serviced. In contrast, Chinese suppliers were not known in Chinese cities and abroad. They had no money to promote their brands in markets where they did not operate.

The "Chinese Top 100 Electronics Company List" ranks Chinese companies based on their annual revenues. This list is well publicized in China and abroad. From 1992 to 2003, Appendix E provides the rankings and revenues for the four Chinese suppliers in this study and the two largest foreign suppliers' joint ventures, Shanghai Bell and BISC $^{8}$. The information in Appendix E shows that no Chinese supplier was among the top 100 electronics companies. However, for 1992, 1993 and 1994, Shanghai Bell ranked 5, 6 and 2 and BISC ranked 73, 19 and 14 in the "Chinese Top 100 Electronics Company List".

\section{Sales personnel}

Chinese suppliers deployed large numbers of sales personnel to the rural areas and counties to proactively search for customers. However, the number of sales personnel working for foreign suppliers was small and most sales personnel were order takers (Cheng \& Liu, 2003; Zhong, 2002).

\footnotetext{
${ }^{8}$ BISC stands for the Beijing International Switching System Co., a Siemens joint venture established in 1990.
} 
Shanghai Bell and BISC, the largest suppliers of SPC switches in China, had less than 29 and 8 sales personnel respectively in 1994 (Zhong, 2002). The demand for telephone service in the cities was so strong that foreign suppliers did not have to proactively search for customers. Foreign suppliers' sales personnel mostly sat in their offices all day taking orders from consumers demanding telephone services. For example, in 1990, Shanghai Bell's manufacturing capacity was 300,000 subscriber lines per year. Its sales of SPC equipment was 430,000 subscriber lines in 1990, 700,000 subscriber lines in 1991, 1.26 million subscriber lines in 1992, and 2.7 million subscriber lines in 1993. Although Shanghai Bell operated a three shifts production schedule, it had less than 29 sales personnel and could not guarantee delivery. The situation was similar for the other foreign suppliers operating in China.

\section{Product development}

Chinese suppliers developed SPC switches in China. Requirements of Chinese rural customers were incorporated into their product development efforts.

Foreign suppliers deployed mature products developed outside of China. These mature products were designed to meet the needs of large service providers in North America, Europe and Japan. For example, Siemen's Technology Division was tasked with modifying the German version of the software to deliver a Chinese version. Product development was undertaken in Germany. Foreign suppliers operated in much the same way. 
Foreign suppliers' SPC switches led Chinese demand for services. Typically, foreign companies invited their Chinese customers to visit their home countries and showed them what the telecommunication equipment of the future looked like.

Nortel Networks was the first foreign supplier to establish an R\&D facility in China. In 1994, Nortel Networks and Beijing University of Post and Telecommunications established an R\&D lab in Beijing. The lab focused on the development of wireless technology.

\section{Manufacturing}

Foreign companies were experienced in the manufacture of high capacity switches prior to starting to service Chinese cities. For example, Ericsson started manufacturing its AXE switch exchanges in 1975 and Alcatel and Siemens started manufacturing their E10B and EWSD switches in 1980. In contrast, Chinese suppliers did not have experience manufacturing high capacity switches.

In 1994, GDT became the first Chinese supplier to establish a line to manufacture high capacity switches. GDT built on the experience gained with the introduction of the HJD04 switch in 1992 by the 04 Group. 


\section{Values}

Survival in the rural market was the first priority for Huawei and ZTE. Thus, they avoided the head to head competition with foreign suppliers servicing the needs of Chinese cities (Cheng \& Liu, 2003).

The second priority was to invest their resource in the $R \& D$ required to develop high capacity switches. In 1988, ZTE invested all the profit generated over the previous four years to develop the ZX500 switch. Similarly, in 1992, Huawei invested all the profits earned from PABX sales and borrowed from large companies to develop the C\&C08A switch. The development of high capacity switches was viewed as an important "break-through" (Cheng \& Liu, 2003; ZTE, 2003)

\subsection{Competitive Convergence: 1995 to 2003}

Table 9 compares the Chinese and foreign telecommunications equipment suppliers from 1995 to 2003 using the constructs of two theoretical perspectives. 
Table 9: The 1995-2003 Competitive Convergence Regime

\begin{tabular}{|c|c|c|c|}
\hline \multirow{2}{*}{$\begin{array}{l}\text { Theoretical } \\
\text { perspective }\end{array}$} & \multirow{2}{*}{$\begin{array}{l}\text { Construct } \\
\text { emphasized }\end{array}$} & Chinese Suppliers & Foreign Suppliers \\
\hline & & $\begin{array}{l}\text { DTT, GDT, Huawei and } \\
\text { ZTE }\end{array}$ & $\begin{array}{l}\text { Alcatel Shanghai Bell } \\
\text { and BISC (joint venture } \\
\text { with Siemens) were the } \\
\text { strongest competitors } \\
\text { inside China. } \\
\text { 3Com, Alcatel, Cisco, } \\
\text { Ericsson, Fujitsu, Lucent, } \\
\text { NEC, Nortel Networks, } \\
\text { and Siemens were the } \\
\text { strongest competitors } \\
\text { outside of China }\end{array}$ \\
\hline $\begin{array}{l}\text { Disruptive } \\
\text { technology }\end{array}$ & Market & $\begin{array}{l}\text { Post and } \\
\text { Telecommunications } \\
\text { Bureaus servicing } \\
\text { consumers in rural and } \\
\text { urban Chinese areas } \\
\text { Service providers in } \\
\text { countries ignored by } \\
\text { established suppliers } \\
\text { such as Cuba, Laos, } \\
\text { North Korea and } \\
\text { Uzbekistan } \\
\text { Service providers in } \\
\text { developing countries } \\
\text { where foreign suppliers } \\
\text { dominated the SPC } \\
\text { switch market and prices } \\
\text { for plain old telephone } \\
\text { services were high } \\
\text { Service providers in } \\
\text { developed nations }\end{array}$ & $\begin{array}{l}\text { Post and } \\
\text { Telecommunications } \\
\text { Bureaus servicing } \\
\text { consumers in rural and } \\
\text { urban Chinese areas } \\
\text { Service providers in } \\
\text { developing and } \\
\text { developed nations }\end{array}$ \\
\hline
\end{tabular}

\footnotetext{
${ }^{9}$ Alcatel Shanghai Bell was established in 2002 by integrating the former Shanghai Bell and Alcatel's key business unit in China. Alcatel owns $50 \%$ plus one share of Alcatel Shanghai Bell.
} 


\begin{tabular}{|l|l|l|}
\hline $\begin{array}{l}\text { Products driving } \\
\text { technological } \\
\text { advances }\end{array}$ & $\begin{array}{l}\text { Low power, high } \\
\text { capacity digital SPC } \\
\text { switches designed to } \\
\text { satisfy the requirements } \\
\text { of Chinese urban and } \\
\text { rural consumers and then } \\
\text { modified to meet the } \\
\text { requirements of foreign } \\
\text { service providers }\end{array}$ & $\begin{array}{l}\text { High capacity digital } \\
\text { SPC switches designed to } \\
\text { satisfy the requirements } \\
\text { of large service providers } \\
\text { in North America and } \\
\text { Europe and then } \\
\text { modified to meet the } \\
\text { requirements of Chinese } \\
\text { urban and rural } \\
\text { consumers as well as } \\
\text { consumers in other } \\
\text { countries }\end{array}$ \\
& $\begin{array}{l}\text { Designed optical } \\
\text { transmission, long } \\
\text { distance wavelength } \\
\text { division multiplexers, } \\
\text { integrated access } \\
\text { networks, digital } \\
\text { subscriber line access } \\
\text { multiplexers, switching } \\
\text { equipment, next } \\
\text { generation networks, } \\
\text { global systems for } \\
\text { mobile communications } \\
\text { to meet the needs of } \\
\text { Chinese urban and rural } \\
\text { customers and then } \\
\text { modified products } \\
\text { deployed in China for } \\
\text { customers outside of } \\
\text { China }\end{array}$ & $\begin{array}{l}\text { Designed optical } \\
\text { transmission, long } \\
\text { distance wavelength } \\
\text { division multiplexers, } \\
\text { integrated access } \\
\text { networks, digital } \\
\text { subscriber line access } \\
\text { multiplexers, switching } \\
\text { equipment, next } \\
\text { generation networks, } \\
\text { global systems for } \\
\text { mobile communications } \\
\text { to meet the needs of large } \\
\text { North American and } \\
\text { European service } \\
\text { providers and then } \\
\text { modified products } \\
\text { deployed for other } \\
\text { customers }\end{array}$ \\
& & \\
& & \\
& & \\
& &
\end{tabular}




\begin{tabular}{|c|c|c|c|}
\hline & $\begin{array}{l}\text { Factors driving } \\
\text { demand }\end{array}$ & $\begin{array}{l}\text { Cheap plain old } \\
\text { telephone service, mobile } \\
\text { and Internet } \\
\text { Fast and good service, } \\
\text { local maintenance office; } \\
\text { total network solutions, } \\
\text { broad product portfolio, } \\
\text { extend existing products } \\
\text { Equipment donated or } \\
\text { financed by the Chinese } \\
\text { government to foreign } \\
\text { governments }\end{array}$ & $\begin{array}{l}\text { Cheap plain old } \\
\text { telephone service, mobile } \\
\text { and Internet } \\
\text { Fast and good service, } \\
\text { local maintenance office; } \\
\text { total network solutions, } \\
\text { broad product portfolio, } \\
\text { extending existing } \\
\text { products }\end{array}$ \\
\hline Capabilities & Technology & $\begin{array}{l}\text { High capacity digital } \\
\text { SPC switches } \\
\text { Broadband access, code } \\
\text { division multiple access, } \\
\text { core routers, integrated } \\
\text { circuits, global systems } \\
\text { for mobile } \\
\text { communications, next } \\
\text { generation networks, } \\
\text { optical transmission }\end{array}$ & $\begin{array}{l}\text { High capacity digital } \\
\text { SPC switches } \\
\text { Broadband access, code } \\
\text { division multiple access, } \\
\text { core routers, integrated } \\
\text { circuits, global systems } \\
\text { for mobile } \\
\text { communications, next } \\
\text { generation networks, } \\
\text { optical transmission }\end{array}$ \\
\hline
\end{tabular}




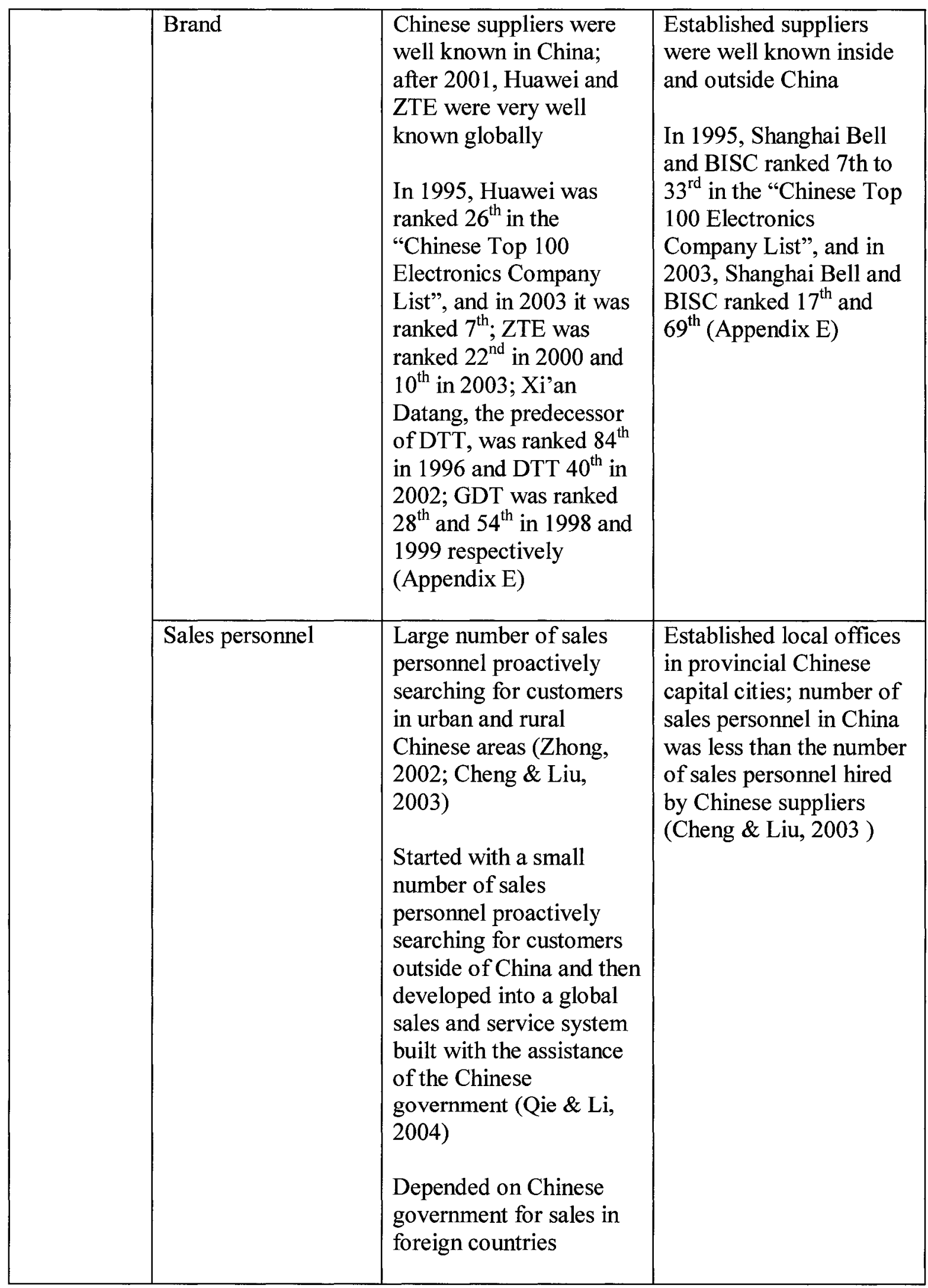




\begin{tabular}{|c|c|c|}
\hline Product development & $\begin{array}{l}\text { Certified as compliant } \\
\text { with the ISO9001 } \\
\text { standard for product } \\
\text { development; Huawei } \\
\text { and ZTE also adopted the } \\
\text { Software Engineering } \\
\text { Institute's Capability } \\
\text { Maturity Model for } \\
\text { software development }\end{array}$ & $\begin{array}{l}\text { R\&D labs outside of } \\
\text { China; Shanghai Bell and } \\
\text { BISC were certified to be } \\
\text { compliant with the } \\
\text { ISO9001 standard; R\&D } \\
\text { labs outside of China also } \\
\text { adopted the Software } \\
\text { Engineering Institute's } \\
\text { Capability Maturity } \\
\text { Model for software } \\
\text { development }\end{array}$ \\
\hline Manufacturing & $\begin{array}{l}\text { Certified as compliant } \\
\text { with the ISO9001 } \\
\text { standard for production, } \\
\text { installation and servicing }\end{array}$ & $\begin{array}{l}\text { Certified as compliant } \\
\text { with the ISO9001 } \\
\text { standard for production, } \\
\text { installation and servicing }\end{array}$ \\
\hline Priorities & $\begin{array}{l}\text { Reduce technological } \\
\text { gaps with foreign } \\
\text { suppliers } \\
\text { Increase equipment } \\
\text { reliability } \\
\text { Displace foreign } \\
\text { companies and their joint } \\
\text { ventures in China and } \\
\text { grow market share in } \\
\text { multiple product lines } \\
\text { outside of China } \\
\text { Maintain costs low }\end{array}$ & $\begin{array}{l}\text { Global market share in } \\
\text { switching, global systems } \\
\text { for mobile } \\
\text { communications, code } \\
\text { division multiple access, } \\
\text { and optical transmission }\end{array}$ \\
\hline
\end{tabular}

Source: (Cheng \& Liu, 2003; China Electronics, 2001; Li \& Cui, 2004; Liu, 2004a; Liu \& Lian, 2004; Ma, 2003; People's Post and Telecom, 2004b;Qie \& Li, 2004; Sun, 2002; Yu, 1999; Zhu \& Pan, 2001;Zhong, 2002; companies' websites) 


\subsubsection{Disruptive Technology Perspective}

\section{Market}

China

From 1995 to 2003, Chinese and established foreign suppliers sold equipment and services to the PTBs responsible for servicing Chinese cities and to PTBs responsible for servicing Chinese rural areas. Starting in 1995, Chinese suppliers deployed their high capacity switches to Chinese cities and established suppliers deployed remote racks into rural areas.

Table 10 provides information on the first deployments of high capacity switches manufactured by Chinese suppliers. In 1992, the 04 Group, the predecessor to GDT, deployed the HJD04 in rural Wuzhi county, Henan Province. This was the first time a Chinese supplier had deployed a high capacity switch. Xi'an Datang, DTT's predecessor, released the SP30 in June 1995; ZTE released the ZXJ10 in November 1995; and Huawei released the C\&C08C in December 1995. Xi'an, Pizhou and Yueyang were three Chinese cities not very well known to North Americans and Europeans. 
Table 10: The First Deployment of Chinese Suppliers' High Capacity Switches

\begin{tabular}{|c|c|c|c|l|}
\hline $\begin{array}{c}\text { Year } \\
\text { switch } \\
\text { was } \\
\text { deployed }\end{array}$ & Supplier & $\begin{array}{c}\text { SPC } \\
\text { Switch }\end{array}$ & $\begin{array}{c}\text { Capacity } \\
\text { (Number of } \\
\text { subscriber lines) }\end{array}$ & $\begin{array}{c}\text { Location of } \\
\text { switch } \\
\text { deployment }\end{array}$ \\
\hline 1992 & $\begin{array}{c}\text { 04 Group (GDT's } \\
\text { predecessor) }\end{array}$ & HJD04 & 10,000 & $\begin{array}{l}\text { Wuzhi county, } \\
\text { Henan Province }\end{array}$ \\
\hline 1995 & $\begin{array}{c}\text { Xi'an Datang } \\
\text { (DTT's predecessor) }\end{array}$ & SP30 & 400,000 & $\begin{array}{l}\text { Xi'an city, } \\
\text { Shaanxi Province }\end{array}$ \\
\hline 1995 & Huawei & C\&C08C & 10,000 & $\begin{array}{l}\text { Pizhou city, } \\
\text { Jiangsu Province }\end{array}$ \\
\hline 1995 & ZTE & ZXJ10 & 170,000 & Yueyang city, \\
& & & & Hunan Province \\
\hline
\end{tabular}

Source: (Companies' websites, Cheng \& Liu, 2003)

In 1995, established suppliers held $90 \%$ share of the Chinese SPC switch market and Shanghai Bell and BISC were the major providers of telecommunications equipment in China. In 1997, however, established suppliers held 50\% market share (Li, 2003).

Figure 7 shows annual revenues for the two most influential joint ventures in telecommunications, Shanghai Bell and BISC, and the four suppliers of telecommunications equipment from 1992 to 2003. By 2003, Huawei and ZTE sold more than Shanghai Bell and BISC becoming the top suppliers of telecommunications equipment in China (China Information Almanac, 2002; Appendix E). 
Figure 7: Annual Revenue of the Joint Ventures Shanghai Bell and BISC and Chinese suppliers DTT, GDT, Huawei and ZTE

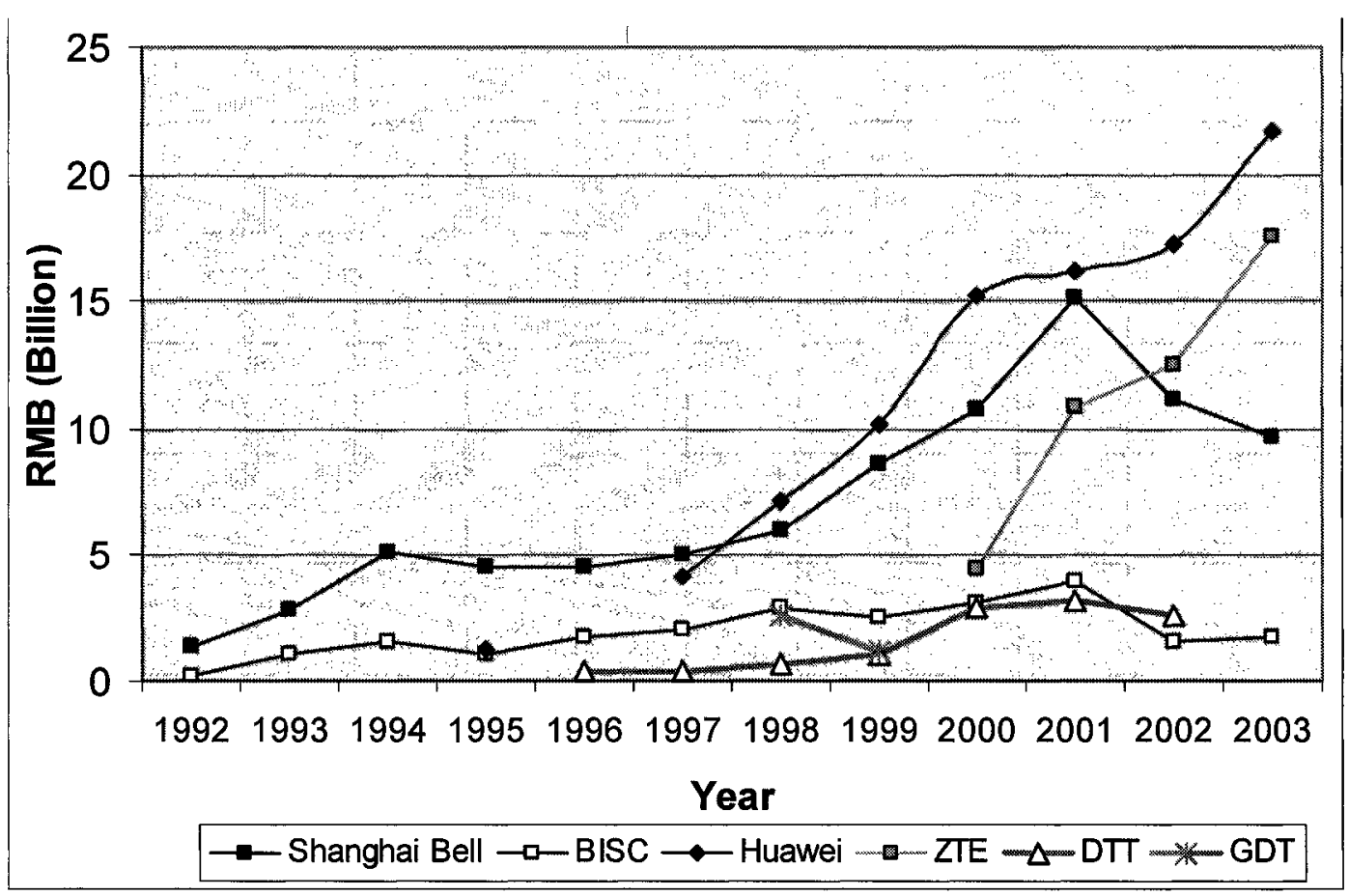

Source: Chinese Top 100 Electronics Company List; 1992-2003

To compete against the established suppliers, Huawei and ZTE relied on low prices and their access network products HONET and ZXA10. For example, in 1999 Shanghai Bell accounted for $90 \%$ of the telecommunications equipment sold in the Sichuan Province. Huawei donated its access network HONET to China Telecom in Sichuan. Once the HONET was deployed in Sichuan, Huawei sold its SPC exchange C\&C08 to Sichuan to interoperate with the donated HONET product. In 2002, Huawei accounted for $70 \%$ of the equipment sold to Sichuan (Sun, 2002). This entry strategy was repeated in other areas in China. 
To compete against Chinese suppliers, established suppliers maintained offices in provincial cities, deployed racks in rural areas, and promoted their equipments' reliable and stable performance.

In addition to the SPC switch market, Chinese suppliers competed aggressively with established foreign suppliers in a variety of other product markets.

\section{Outside of China}

Table 11 identifies the countries to which Chinese suppliers exported their SPC switches and network products by year and by company. It does not include exports of integrated circuits.

Table 11: Countries to Which Chinese Suppliers Exported High Capacity Switches, and Networks

\begin{tabular}{|l|l|l|l|l|}
\hline Year & DTT & GDT & Huawei & ZTE \\
\hline 1994 & & North Korea & & \\
\hline 1995 & & & & \\
\hline 1996 & & & & Pakistan \\
\hline 1997 & & & Uzbekistan & Yugoslavia \\
\hline 1999 & & Cuba & $\begin{array}{l}\text { Ecuador, Laos, } \\
\text { Yemen }\end{array}$ & $\begin{array}{l}\text { Egypt, Germany, } \\
\text { Pakistan, Thailand, } \\
\text { Zimbabwe }\end{array}$ \\
\hline 2000 & & $\begin{array}{l}\text { Bangladesh, Congo, } \\
\text { Cyprus, Kenya, } \\
\text { Turkmenistan, } \\
\text { Yemen }\end{array}$ \\
\hline 2001 & & & $\begin{array}{l}\text { Australia, Kenya, } \\
\text { Russia, Spain }\end{array}$ & Egypt \\
\hline
\end{tabular}




\begin{tabular}{|l|l|l|l|l|}
\hline 2002 & & $\begin{array}{l}\text { Argentina, Brazil, } \\
\text { Chile, Indonesia, } \\
\text { Malaysia, Nigeria, } \\
\text { United States }\end{array}$ & $\begin{array}{l}\text { Ecuador, India, } \\
\text { Kuwait, Philippine, } \\
\text { Zambia, }\end{array}$ \\
\hline 2003 & $\begin{array}{l}\text { Indonesia, } \\
\text { Iran }\end{array}$ & $\begin{array}{l}\text { Brazil, Britain, } \\
\text { Ethiopia, France, } \\
\text { Indonesia, United } \\
\end{array}$ & $\begin{array}{l}\text { Arab Emirates, } \\
\text { Portugal }\end{array}$ & $\begin{array}{l}\text { Mexico, Romania, } \\
\text { Russia }\end{array}$ \\
& & & \\
\hline
\end{tabular}

Source: (Cheng \& Liu, 2003; China Electronics News, 2003; Guo, 2004; Liu, 2004a; Liu, 2004b; Qie \& Li, 2004; Sun, 2002; Companies' websites)

The information in Table 11 indicates that:

- The 04 Group was the first Chinese supplier to export a high capacity switch. The 04 Group exported the HJD04 to North Korea in late 1994.

- Chinese suppliers in the study started exporting in 1998

- The majority of the Chinese suppliers' foreign customers are located in developing nations

- Only one of the four Chinese suppliers has sold to customers in developed nations. Huawei has sold to customers in Australia, France, and Germany and the United States

Liu (2004a) and Cheng and Liu (2003) suggest that Chinese suppliers targeted countries that were neglected by the established foreign companies or were in a similar situation that China had been in the early 1990 s with respect to the supply of voice communication services. The authors identify Russia as an example of the type of new markets Chinese pursued. When Russia fell into an economic recession in 
1997, established suppliers such as Alcatel, NEC, and Siemens retreated away from Russia. That same year Chinese suppliers designed a plan to enter the Russian telecommunications market and sent 100 sales people to Russia.

\section{Products}

From 1998 to 2003, high capacity digital SPC switches, intelligent networks, data products, integrated circuits, and mobile systems drove technological advances for both Chinese and established suppliers.

Table 12 identifies the product markets in which BISC, Alcatel Shanghai Bell, and the four Chinese suppliers of telecommunications equipment operated as of 2003. All six suppliers offered products in three product markets: switching, intelligent networks, and data routers. 
Table 12: Product Markets in Which Alcatel Shanghai Bell, BISC, and Chinese Equipment Suppliers Operated as of 2003

\begin{tabular}{|l|c|c|c|c|c|c|}
\hline Products & $\begin{array}{c}\text { Alcatel } \\
\text { Shanghai } \\
\text { Bell }\end{array}$ & BISC & DTT & GDT & Huawei & ZTE \\
\hline Switching & $\sqrt{ }$ & $\sqrt{ }$ & $\sqrt{ }$ & $\sqrt{ }$ & $\sqrt{ }$ & $\sqrt{ }$ \\
\hline Access & $\sqrt{ }$ & $\sqrt{ }$ & & & $\sqrt{ }$ & $\sqrt{ }$ \\
\hline $\begin{array}{l}\text { Intelligent } \\
\text { networks }\end{array}$ & $\sqrt{ }$ & $\sqrt{ }$ & $\sqrt{ }$ & $\sqrt{ }$ & $\sqrt{ }$ \\
\hline $\begin{array}{l}\text { New generation } \\
\text { networks }\end{array}$ & $\sqrt{ }$ & $\sqrt{ }$ & & & $\sqrt{ }$ & $\sqrt{ }$ \\
\hline $\begin{array}{l}\text { Optical } \\
\text { transmission }\end{array}$ & $\sqrt{ }$ & $\sqrt{ }$ & $\sqrt{ }$ & $\sqrt{ }$ & $\sqrt{ }$ & $\sqrt{ }$ \\
\hline $\begin{array}{l}\text { Data routers } \\
\text { Global systems } \\
\text { for mobile } \\
\text { communications }\end{array}$ & $\sqrt{ }$ & $\sqrt{ }$ & $\sqrt{ }$ & $\sqrt{ }$ & $\sqrt{ }$ \\
\hline $\begin{array}{l}\text { Code division } \\
\text { multiple access }\end{array}$ & $\sqrt{ }$ & & $\sqrt{ }$ & & $\sqrt{ }$ & $\sqrt{ }$ \\
\hline $\begin{array}{l}\text { Code division } \\
\text { multiple access } \\
\text { 2000 }\end{array}$ & & & & & $\sqrt{ }$ & $\sqrt{ }$ \\
\hline $\begin{array}{l}\text { Wideband code } \\
\text { muivision } \\
\text { multiple access }\end{array}$ & & & & $\sqrt{ }$ & $\sqrt{ }$ \\
\hline \begin{tabular}{l} 
Mobile phones \\
\hline
\end{tabular} & & & & & & \\
\hline
\end{tabular}

Source: Companies' websites.

In China, Chinese suppliers provided low power, high capacity digital SPC switches designed to satisfy the requirements of Chinese consumers and PTBs. Established foreign suppliers deployed modified versions of high capacity digital SPC switches 
originally designed to satisfy the requirements of large service providers in North America, Europe and Japan.

Foreign companies and Chinese companies had similar product lines. However, the stability of established companies' products was better than the stability of Chinese suppliers' products. In 1998, during a lecture to China Telecom and China Unicom, Huawei's CEO Mr. Ren Zhengfei said "We are targeting the best companies in the telecommunication industry such as Siemens, Alcatel, Ericsson, Lucent, and Nokia. Our products and administration planning must get close to theirs, follow them and exceed them. Our SPC exchange has more new functions and features, but we are lagging in stability and reliability. We can survive only if we aim to be the best."

\section{Factors driving demand}

China Telecom, as most service providers around the world, required stable and diverse products for voice, data, mobile and Internet services, and maintenance and extensions for existing equipment. Moreover, they needed fast and good service, local maintenance offices and network solutions. Low prices were also a key requirement.

Table 13 compares prices charged by PTBs operating switches developed by Chinese and established foreign suppliers. In 1995, prices charged by established foreign suppliers were much higher than those charged by Chinese suppliers. Aggressive competition in China drove down the prices. By 1999, the price discrepancy observed in 1995 had disappeared. 
Table 13: Price Comparison (US \$ per Public Switched Telephone Network Line)

\begin{tabular}{|l|l|l|l|}
\hline Year & $\begin{array}{l}\text { Chinese } \\
\text { Suppliers }\end{array}$ & $\begin{array}{l}\text { Foreign } \\
\text { Companies }\end{array}$ & Reference \\
\hline 1995 & $\$ 80$ & $\$ 150$ & $\begin{array}{l}\text { (Cheng \&Liu, } \\
2003)\end{array}$ \\
\hline 1997 & $\$ 50-\$ 70$ & & $($ Yu, 1999) \\
\hline 1998 & $\begin{array}{l}\$ 50-\$ 70, \\
\text { sometimes } \\
\$ 25\end{array}$ & & $($ Yu, 1999) \\
\hline 1999 & $\$ 30-\$ 50$ & $\begin{array}{l}\$ 30-\$ 50, \\
\text { sometimes } \$ 18\end{array}$ & $\begin{array}{l}\text { Zhong, 2000; } \\
\text { Zhu } \\
\text { 2001) }\end{array}$ \\
\hline
\end{tabular}

\subsubsection{Capabilities Perspective}

\section{Technology}

During the competitive convergence regime, Chinese suppliers reduced the technology gap that existed during the competitive isolation regime. By 2003, Chinese and foreign suppliers offered similar product lines. Chinese suppliers had access to the same advanced technologies used by established foreign suppliers. For example, Huawei developed the R4 version of wideband code division multiple access (WCDMA) equipment based on softswitch technology and manufactured the whole series of ASIC chips for WCDMA. ZTE was the only company in the world manufacturing phones for the global system for mobile communications (GSM), code division multiple access (CDMA), personal handyphone system (PHS) and $3^{\text {rd }}$ generation mobile telecommunications. DTT developed the Chinese $3 \mathrm{G}$ standard TD-SCDMA (China Comms Network, 2003). 
To keep costs down, Chinese suppliers design their own complex integrated circuits, products and systems. There is evidence that Chinese suppliers' prices were lower than those of established suppliers:

- In 2001, Huawei agreed to provide dense wavelength division multiplexers for LDCOM's backbone optical transmission network in France at a 40-50\% cost saving (Qie \& Li, 2004)

- In 2002, the cost of Huawei's integrated circuits was $\$ 10$ US per chip, the cost of similar chips designed by others was $\$ 200$ US per chip (Sun, 2002)

- In 2003, due to competition from Chinese suppliers, the cost of GSM switching systems dropped from $\$ 400$ US per line to $\$ 80$ US per line (China Electronics News, 2003)

- Huawei's data products were $30 \%$ cheaper than Cisco's products (Peter, 2003)

- Li and Cui (2004) estimate that Chinese suppliers products were 30 to $50 \%$ cheaper when compared to established competitors' products

\section{Brand}

At the start of the competitive convergence regime, Chinese suppliers became very well known in China. The names of the four Chinese suppliers were often used together as a brand "Ju (GDT), Da (DTT), Zhong (ZTE), Hua (Huawei)" (Cheng \& Liu, 2003).

In 2003, Huawei and ZTE were ranked $7^{\text {th }}$ and $10^{\text {th }}$ in the "Chinese Top 100 Electronic Company List." 
Starting in 2002, Huawei and ZTE became well known globally. For example, Huawei's and ZTE's competitive aggressiveness were noted in Siemens' annual reports for 2002 and 2003. In 2002, Cisco established the "Beat Huawei" group to rally competitive efforts against the Chinese supplier. In 2001, market share tracking firms started ranking Huawei and ZTE in various product markets. Executives of established companies started making public speeches warning about the competitive aggressiveness of Chinese telecommunications equipment suppliers.

\section{Sales personnel}

In China

Chinese suppliers maintain a larger number of sales and service offices in China than do established foreign suppliers and their joint ventures. Table 14 provides the number of sales and service offices for Shanghai Bell, BISC, and the four Chinese suppliers as of 2003. Shanghai Bell and BISC maintained 14 and 10 offices in China respectively. Each of the four Chinese suppliers maintained a greater number of offices.

Huawei and ZTE had 10 to 30 sales and service people in each Chinese province. However, foreign companies like Siemens and Alcatel had only 2 to 3 people in most provinces. For example, Ericsson and Huawei had four and 200 sales and service people respectively in Heilongjiang province (Cheng \& Liu, 2003). 
Huawei had 200 district business organizations besides the local offices in China (Sun, 2002).

Table 14: Number of Sales and Service Offices in China as of 2003

\begin{tabular}{|c|c|c|c|c|c|}
\hline $\begin{array}{c}\text { Shanghai } \\
\text { Bell }\end{array}$ & BISC & Huawei & ZTE & GDT & DTT \\
\hline 10 & 14 & $\begin{array}{c}30 \text { sales and } \\
35 \text { service offices }\end{array}$ & 30 & 16 & 25 \\
\hline
\end{tabular}

Source: companies' websites

At the start of the competitive convergence regime, Chinese sales personnel depended on the Chinese government for introductions to influential individuals in foreign countries. Most Chinese suppliers sent a few sales people searching for opportunities in the global market.

Huawei, however, was less dependent on Chinese government help for its sales and would send a greater number of sales personnel to search for opportunities in foreign countries. For example, Huawei sent 100 sales people to Russia to develop the Russian market in 1997 (Qie \& Li, 2004).

Two of the four Chinese suppliers are establishing sales and service offices outside of China to build a global sales system (Liu, 2004b). Table 15 provides the number of sales offices the four equipment suppliers maintained as of 2003. 
Table 15: Number of Chinese Suppliers' Offices Overseas as of 2003

\begin{tabular}{|l|l|l|l|}
\hline Huawei & ZTE & DTT & GDT \\
\hline 50 & 37 & 0 & 3 \\
\hline
\end{tabular}

Source: Companies’ websites.

Established suppliers already have well established sales systems worldwide. For example, Alcatel, Lucent and Siemens have 43, 26 and 85 subsidiary companies around the world.

Chinese suppliers hired sales personnel let go by established suppliers during the recent recession. For example, when Alcatel and Siemens closed their offices in developing countries, ZTE hired the people working in these offices (Ben, 2004).

\section{Product development and manufacturing processes}

Chinese suppliers adopted the ISO standards and processes being used by the established suppliers. Table 16 shows the year in which the four Chinese suppliers and three joint ventures became compliant with nine standards adopted by established suppliers. Appendix H provides a description of the various standards shown in Table 16. 
Table 16: Process Adopted by SPC Equipment Suppliers Operating in China

\begin{tabular}{|l|l|l|l|l|l|l|l|}
\hline & $\begin{array}{l}\text { Shanghai } \\
\text { Bell }\end{array}$ & BISC & $\begin{array}{l}\text { Lucent } \\
\text { (Qingdao) }\end{array}$ & Huawei & ZTE & DTT & GDT \\
\hline ISO9002 & & 1995 & & & & & \\
\hline ISO9001 & 1995 & 1996 & 1997 & 1995 & 1995 & 2000 & 2000 \\
\hline ISO14001 & 2000 & 2000 & 1997 & & & & \\
\hline TL9000 & 2003 & & 2001 & 2002 & & & \\
\hline CMM & & & & 1999 & 2003 & & \\
\hline IPD & & & & 1999 & 2003 & & \\
\hline ISC & & & & 1999 & 2003 & & \\
\hline NVQ & & & & 1998 & & & \\
\hline WMS & & & & 2001 & & & \\
\hline
\end{tabular}

Source: Companies' websites.

The information in Table 16 shows that:

- All suppliers were compliant with the ISO 9001 standard as of 2000

- Huawei and ZTE are compliant to a greater number of standards than the other suppliers

\section{Priorities}

Chinese and established suppliers place a priority on increasing market share in key global product markets. 
Chinese suppliers have four priorities:

1. Use low prices as a source of competitive advantage

2. Reduce the technological gaps with foreign suppliers

3. Increase equipment reliability

4. Displace foreign companies and their joint ventures in China and grow market share in multiple product lines outside of China 


\section{DISCUSSION OF RESULTS}

This research uses a chronology of key events and constructs from two theoretical perspectives to examine four Chinese suppliers of telecommunications equipment over an 18-year period.

This chapter is organized into two sections. The first section provides an analysis of the chronology of key events of Chinese suppliers and the comparison between Chinese and established suppliers provided in chapters 4 and 5 . The second section provides an answer to the research question: Can Professor Clayton Christensen's models explain how Chinese makers of telecommunications equipment became serious global competitors in less than 20 years?

\subsection{Overview}

The analysis of the chronology of key events of Chinese suppliers and the comparison between Chinese and established suppliers provided in chapters 4 and 5 suggests that from 1987 to 1994, the four Chinese suppliers commercialized their low capacity SPC switches in a specialized niche: Chinese rural areas. All four developed high capacity SPC switches and in 1995 went on to penetrate the Chinese urban market.

The Chinese suppliers first sold cheap high capacity switches to customers in Chinese cities not well known to foreigners and then moved to sell them to customers in cities 
where joint ventures with foreign partners and foreign suppliers had operated for many years.

In China, all four Chinese suppliers used aggressive low cost strategies to compete in urban and rural areas. In 2002, the combined market shares of two of the four Chinese suppliers, Huawei and ZTE, account for more than $40 \%$ in six Chinese product markets: (i) switching and access, (ii) optical networks, (iii) asymmetric digital subscriber lines, (iv) intelligent networks, (v) mobile data, and (vi) personal handyphone systems (Norson, 2002).

Outside of China, Chinese suppliers first targeted customers in countries ignored or abandoned by foreign suppliers. In 1994, the government of North Korea, with the help of the Chinese government, was the first organization to import a high capacity switch produced in China. From 1998 to 2000, three of the four Chinese suppliers, with more help from the Chinese government, sold high capacity SPC switches to customers in developing nations such as Bangladesh, Congo, Cuba, Colombia, Cyprus, Ecuador, Kenya, Laos, Pakistan, Turkmenistan, Uzbekistan, Yemen, and Yugoslavia.

In 2001, Huawei started to compete aggressively against incumbent global suppliers and shortly afterwards became the number one supplier in the global market for new extended switching equipment (Dittbener, 2004a), the number one supplier in the global market for new generation networks (Dittbener, 2004b), the number two 
supplier in the global market for digital subscriber line access multiplexers (Gartner, 2003), the number three supplier in the global market for long distance wavelength division multiplexers (RHK, 2004a), the number fourth supplier in the global market for optical transmission (RHK, 2004b), and the number three supplier in the global market for integrated access networks (RHK, 2004c).

\subsection{Answering the Research Question}

\section{Technology disruption perspective}

The technology disruption perspective is fundamentally a view on what are the factors and dynamics that increase rivalry in a product market. A technology disruption results in both new companies and incumbents facing more competitors.

\section{China}

Using the technology disruptive perspective the growth of Chinese equipment suppliers in China can be characterized as follows. From 1985 to 1994, the Chinese SPC market can be divided into at least two segments:

- A primary market comprised of PTBs in urban areas that cared about satisfying high density areas, stable equipment performance, and functionality that enabled switches to operate as SSPs

- A new market comprised of PTBs in rural areas that cared about very cheap, low power, easy to operate switches with basic functions and Chinese interfaces 
High capacity SPC switches manufactured by foreign suppliers or joint ventures with foreign partners were used in the Chinese urban market. The small capacity switches manufactured by the Chinese suppliers were used in Chinese counties, rural and mountain areas. Thus, the two technologies were isolated, each limited to servicing customers in a different market segment.

Low capacity SPC switches offered a novel mix of benefits to rural PTBs compared to high capacity switches. They were very cheap, required low power, and did not need educated professionals to operate them. High capacity switches were overpriced relative to the benefits that Chinese consumers in rural areas could derive from their use.

Compared to the high capacity switches sold by established foreign suppliers, the Chinese low capacity switches were inferior technology. They could not be used to serve large, high-density Chinese cities.

With time, the performance of the low capacity switches manufactured by Chinese suppliers improved, but the high capacity switches manufactured by foreign companies were deemed to be superior by PTBs in urban areas. The R\&D of established foreign suppliers was focused on bringing better products into the established market comprised of large, high-density cities in China. 
In 1995, the Chinese suppliers started to deploy very cheap, high capacity switches into Chinese cities. They first targeted PTBs responsible for cities that were not well known to foreigners. These cities can be thought of as being either non consumers of voice services or overshot customers. If a PTB was not operating a high capacity switch manufactured by an incumbent, the PTB was a non-consumer of voice services. If a PTBs was operating a high capacity switches manufactured by an incumbent, the PTB was an overshot customer.

Starting 1995, Chinese suppliers pursued a low price, high volume strategy to break into the large, high-density city market in China. These cities had been serviced by incumbent suppliers for many years. In 2003, Chinese suppliers were competing head to head with foreign suppliers and their joint ventures in China.

From the technology disruption perspective, incumbents undertook sustaining innovations. They improved their existing high capacity SPC switches along the dimensions the PTBs responsible for servicing Chinese cities valued. The Chinese suppliers introduced two types of disruptive innovations: (i) new market from 1985 to 1994 and (ii) low-end from 1995 to 2003.

The introduction of low capacity switches into Chinese rural areas was a new market innovation. It made it easier for consumers in Chinese rural areas to talk to one another. The low capacity switches brought consumption of voice services to nonconsumers. 
The introduction of Chinese produced high capacity switches into Chinese cities which were not well known to foreigners was either a new market innovation or a low-end innovation depending on whether or not the city was serviced by a PTB that operated incumbents' switches.

The introduction of Chinese produced high capacity switches into large, high density Chinese cities served by PTBs that operated incumbents' switches was a low-end innovation.

\section{Outside of China}

Using the technology disruptive perspective the growth of Chinese equipment suppliers outside of China can be characterized as follows. From 1995 to 2003, the global SPC market can be divided into at least two segments:

- A primary market comprised of large service providers in developed nations that cared about profits, stable equipment performance, adoption of international standards for equipment interoperability and the deployment of integrated network solutions to provide voice, mobile and Internet services

- A market comprised of service providers in developing countries that was overpaying for the existing products and services they received relative to the benefits their customers could derive 
High capacity SPC switches manufactured by well established North American, European and Japanese suppliers and their joint ventures with local partners were used to satisfy the needs of both markets. Thus, the two markets were not isolated. Service providers in developing countries were sold versions of SPC switches designed for large service providers in developed countries.

With time, the performance of high capacity SPC switches continued to improve and the gap between what the switch could supply and what consumers in developing nations could use widened.

Chinese suppliers first targeted service providers in countries that had been ignored or abandoned by established suppliers. Chinese suppliers avoided competing with incumbent suppliers in the early years of their sales to customers in other countries. Most, if not all, these early exports were funded directly or indirectly by the Chinese government.

Starting 1998, Chinese suppliers entered developing nations serviced by incumbents with a low cost strategy. The Chinese suppliers offered very cheap, relatively straightforward products to service providers in developing nations.

Starting 2000, Huawei and ZTE entered the developed countries market with a very low cost strategy. 
From the disruptive technology perspective, the introduction of Chinese produced high capacity switches into countries isolated from developed nations was either a new market innovation or a low-end innovation depending on whether or not the area where the switch was deployed was serviced by incumbents' switches.

The introduction of Chinese produced high capacity switches into service providers previously served by established suppliers of switches was a low-end innovation.

The introduction of Chinese produced high capacity switches into large service providers in developed countries was a low-end innovation.

\section{Capabilities Perspective}

The capabilities perspective is fundamentally a view that explains why incumbents have difficulties responding to new entrants with technology disruptions. The argument is that companies undertake opportunities when they have the resources to succeed, the processes to do what needs to get done and the values that give these opportunities adequate priority.

From the capabilities perspective, incumbents had proven technology embedded in their high-capacity switches, broad product portfolios, excellent global brands, and years of experience developing and manufacturing switches. 
Compared to Chinese suppliers, incumbents had fewer sales people and more order takers in China; had fewer R\&D personnel in China; had well established global sales systems; required higher profits; and sought to increase their shares in various global product markets, not just the SPC switching market.

Compared to incumbents, Chinese suppliers had lower costs of $R \& D$, sales and production; access to significant help for exports from the Chinese government and a strong desire to reduce the technological gap with incumbent suppliers. In the case of Huawei, the company also had a strong leadership and a clear vision anchored around conquering global markets. 


\section{CONCLUSIONS, LIMITATIONS AND SUGGESTIONS FOR FUTURE RESEARCH}

\subsection{Conclusion}

The objective of this research was to use two of Professor Clayton Christensen's models to explain how Chinese suppliers of telecommunications equipment became serious competitors worldwide in a relative short time.

A chronology of the key events in the history of four Chinese suppliers of SPC switches was used to identify two competitive regimes: a competitive isolation regime from 1985 to 1994 and (ii) a competitive convergence regime from 1995 to 2003 . For each competitive regime, 9 constructs emphasized by two theories of innovation deemed to be core by Christensen, Anthony and Roth (2004) were used to compare Chinese and foreign equipment suppliers.

Finally, the chronology and the comparisons were used to provide a formal answer to the research question. 
The main benefits of using theory in this research study were two. First, the models helped identify the information that really matters. This helped identify the constructs needed to carry out the research and make sense of what seemed to be an infinite amount of data. Data acquisition was not the main problem, making sense of data was. There is an abundance of information on the Internet and elsewhere. Without suitable models it is very hard to decide what information really matters and to make sense of the information that does.

The second benefit of using Christensen's models was the discipline developed to generate insights about the past. Insights were generated using constructs highlighted by models instead of assumptions based on industry nuances or skill preferences.

Both models used in this research generated insights on why Chinese equipment suppliers grew so quickly. The disruptive innovation theory provided the greater number of insights. It was more difficult to generate insights from the use of the value chain theory. Thus, it was dropped from the research.

While the two models provided insights, they were not easy to apply in this situation for three reasons. First, the models and their theories lack formality. The constructs needed to be detailed before they could be applied. Second, important constructs that were known to have affected the growth of Chinese suppliers were not incorporated into the theories. For example, it is clear that the size of the mainstream market, breadth of product portfolio and the initial niche market affected the growth of the 
Chinese equipment suppliers. However, given the models selected there was no easy way to incorporate the size dynamics into the analysis. This was true for other factors as well such as the number of firms developing the low capacity switches, innovation incentives and multi-product portfolios.

Before the author adopted Christensen's models for this research, other method were used in an attempt to explain the changes of Chinese suppliers. These methods failed to generate insights that would satisfy a thesis examination committee. The failed attempts include the use of the following methods:

- System of innovation (Carlsson, 2002; Edquist, 2003; Malerba 2002)

- Technology life cycle (Kim, 2003; Moore, 2002)

- Competitive aggressiveness framework (Ferrier, 2001)

The author of this thesis found that Christensen's models and Adner's competitive regimes worked better to explain the changes of Chinese suppliers from 1985 to 2003 .

\subsection{Limitations}

This study has at least three limitations. First, the "goodness" of the insights was not validated with expert personnel. This was simply not possible to accomplish given the cost that this would have entailed.

The second limitation is that Christensen's model of disruptive innovations shown in Figure 1 works well for a single product scenario. The Stored Program Controlled 
(SPC) switches' development is a good application of Christensen's model during the period of competitive isolation. However, after 1995 Chinese suppliers and established foreign companies competed head-on using product portfolios not a single product. These portfolios included NGN, GSM, CDMA, 3G, and optical transmission equipment. Competition was no longer anchored on just a single product. Christensen's disruptive innovation model is limited for situations in which competition is anchored around a product portfolio.

The third limitation is due to the fact that an adequate theoretical perspective that handles multiple technology firms and responses to low-end innovation has not matured yet. Developing such a perspective was outside the scope of this research.

\subsection{Suggestions for Future Research}

There are three suggestions for future research. First, formalize the disruptive technology perspective so it is easier to apply and incorporates more of the factors that may help explain the phenomenon of disruptive technologies. The paper by Adner and Zemsky (2003) is a start in this direction.

The second suggestion is to undertake empirical research seeking to validate the relationships and the dynamics implied by the disruptive technology perspective.

The third suggestion is to modify the research method used in this study so it can be used to: 
- make and validate predictions

- explain differences in companies' performance 


\section{REFERENCES}

1. Adner, R. 2002. When are technologies disruptive? A demand based view of the emergence of competition. Strategic Management Journal. 23: 667-688.

2. Adner, R. 2001. Disruptive Technologies and the Emergence of Competition. INSEAD Working Paper 2001/103/SM.

3. Ben, D. 2004. Chinese telecommunication equipment suppliers in the international market. Wall Street Journal. February 26. http://www.huawei.com.cn/news/media/1701.shtml Accessed December 7, 2004.

4. Bower, J.L. and Christensen, C. M. 1995. Disruptive technologies: catching the next wave. Harvard Business Review. 73(1): 43-53.

5. Carlsson, B., Jacobsson S., Holmen M. and Rickne A. 2002. Innovation systems: analytical and methodological issues. Research Policy. 31: 233 - 245.

6. Ccidnet. 2001. Why Alcatel wants to acquire Lucent? May 25. http://www0.ccidnet.com/economics/comment/2001/05/25/75 6005.html accessed December 6, 2004.

7. Cheng, D. and Liu, L., 2003. The Truth of Huawei. Beijing: Contemporary China Press.

8. China Comms Network. 2003. The 3G is DTT's last hope. http://www.c114.net/ news/companynewsread_c114.asp?articleid=9722. Accessed in November 9, 2004

9. China Electronics News. 2001. ZTE's IP telephone system enters US. July 16.

10. China Electronics News. 2003. International market refuses opportunism. May 19. 
11. Christensen, C.M. 1997. The innovator's dilemma: when new technologies cause great firms to fail. Boston, MA: Harvard Business School Press.

12. Christensen, C.M., Anthony S.D. and Roth E.A. 2004. Seeing what's next? : using the theories of innovation to predict industry change. Boston, MA: Harvard Business School Press.

13. Christensen, C. M., Johnson M.W. and Rigby D.K. 2002. Foundations for growth - how to identify and build disruptive new businesses. MIT Sloan Management Review, Spring 2002: 22-31.

14. Christensen, C.M. and Overdorf M. 2000. Meeting the challenge of disruptive change. Harvard Business Review, March-April 2000: 66-76.

15. Christensen, C.M. and Raynor, M.E. 2003. The Innovator's Solution: Using Good Theory to Solve the Dilemmas of Growth. Boston, MA: Harvard Business School Press.

16. Christensen, C.M., Raynor, M.E., and Verlinden, M. 2001. Skate to Where the Money Will Be. Harvard Business Review. November: 72-81.

17. Christensen, C.M. and Rosenbloom, R. 1995. Explaining the attacker's advantage: technological paradigms, organizational dynamics, and the value network. Research Policy 24(2): 233-257.

18. Christensen, C.M., Verlinden, M. and Westerman, G. 2002. Disruption, Disintegration, and the Dissipation of Differentiability. Industrial and Corporate Change 11(5):955-993.

19. DeWoskin J. 2001. The WTO and the telecommunications sector in China. The China Quarterly. $630-654$. 
20. Dittberner. 2004a. Worldwide digital switching status and forecast. http://www.huawei.com.cn/about/yeji.shtml Last examined December 19, 2004.

21. Dittberner. 2004b. Global NGN equipment market in the first half of 2004. http://www.huawei.com.cn/about/yeji.shtml Last examined December 19, 2004.

22. Dong J. 2003. TD-SCDMA: DTT's burden. Sohu IT. October 24. http://it.sohu.com/18/20/article214772018.shtml . Accessed November 20, 2004

23. Du Q. \& Wang M. 1997. The consideration of Shenzhen's SPC switches industry. Shenzhen Special District News. May 13.

24. Edquist, C., 2003. The Internet and Mobile Telecommunications System of Innovation - Developments in Equipment, Access and Content. Edward Elgar Publishing.

25. Ferrier, W. J. 2001. Navigating the Competitive Landscape: the Drivers and Consequences of Competitive Aggressiveness. Academy of Management Journal 44(4): 858-877.

26. Gao H. 2002. Can Great Dragon be rebuilt? China Business. November 25.

27. Gartner. 2003. Global Shipment of DSLAM in the first three quarters of 2003. http://www.huawei.com.cn/about/yeji.shtml Last examined December 19, 2004.

28. GDT, 2003. Events list of GDT. http://www.gdt.com.cn/about/index2.php?page=2 . Accessed on December 18, 2004. 
29. Guo K. 2004. Stepping out will see opportunities. CEO\&CIO China. August 18.

30. Hamblen, M. 2004. Nortel CEO sees exciting future. Computerworld. September 1. http://www.computerworld.com.au/index.php/id;42262853;fp;512:fpid;18767526 95 Last examined December 4, 2004.

31. Huawei, 2003a. Introduction of Huawei. http://www.huawei.com.cn/about/index.shtml . Accessed on December 18, 2004.

32. Hauwei, 2003b. Financial performance of Huawei. http://www.huawei.com.cn/about/yeji.shtml . Accessed on December 18, 2004.

33. Jin D. 2001. Lucent divulged its "obsolete" technology. Nanfang Zhoumo Weekly. May $11^{\text {th }}$. http://tech.china.com/zh_cn/news/lucent/167787/20010511/176061.html accessed December 6, 2004.

34. Kim, B. 2003. Managing the Transition of Technology Life Cycle. Technovation, (23): 371-381.

35. Li X. 2003. The fighting between Cisco and Huawei - who is the winner? Software World. March 28. http://news.ccidnet.com/pub/article/c379 a41818 p1.html Accessed December 5, 2004.

36. Li C. \& Cui H. 2004. The Report of Huawei's Strategy for International Market. IT Time Weekly. September 20.

37. Li Y. 2003. Win Respect by Knowledge. People's Daily. April 17: 13. 
38. Liu J. 2002. ZTE is building the No.1 CDMA brand in China. China Electronics News. January 22.

39. Liu Q. 2004a. Why Huawei Succeed Overseas. China Telecom World. July 28.

40. Liu Q. 2004b. Ten years of hard work proves itself. Telecommunication World. August 17.

41. Liu Y. 2004. Huawei: speak by capability in the international market. China Electronics News. January 13.

42. Liu Y. \& Lian X. 2004. Huawei's sales reached RMB 30 billion in 2003. China Electronics News. January 12.

43. Lu A. 2003. ZTE Bet the CDMA. http://tech.tom.com/Archive/1796/1823/2003/6/24-59172.html . June 24. Accessed November 20, 2004.

44. Lu C. 2000. Innovations help accelerate Huawei. Guang Ming Daily. October 22.

45. Liu C. 2003. The road of Datang's SP30 series. People's Post and Telecom Daily. December 25. http://www.cnii.com.cn/20030915/ca218066.htm . Accessed on December 18, 2004.

46. Ma X. 2003. ZTE is building the 3G network for China. Tongxin Xinxi Weekly. August 25.

47. Malerba F., 2002. Sectoral Systems of Innovation and Production, Research Policy, (31): 247-264.

48. Ministry of Information Industry. 1994-2003. The development status of Chinese telecommunication industry in 2003. http://www.mii.gov.cn/mii/hyzw/tongij/ tongjifenxi200312.htm. Accessed November 9, 2004. 
49. Ministry of Information Industry. 1991 - 2003. The annual statistics report of telecommunication industry. http://www.mii.gov.cn/mii/hyzw/tjxx.html. Accessed November 9, 2004.

50. Moore G. A., 2002. Crossing the Chasm: Marketing and Selling High-Tech Products to Mainstream Customers. HarperBusiness.

51. National Bureau of Statistics of China. 1996. Annual per capita income and index of urban and rural household. http://www.stats.gov.cn/ndsj/information/zh1/i041a accessed December 17, 2004.

52. Norson. 2002. Chinese Telecommunications Equipment Market Comparison for 2002. http://www.cnii.com.cn/20030218/ca139880.htm Last examined December $20,2004$.

53. Ouyang J. 2003. Huawei: improve itself in the international competition. Tongxin Xinxi Weekly. December 30.

54. People's Post and Telecom Daily. 2003. Succed by technology innovations. June 3.

55. People's Post and Telecom Daily. 2004a. DTT released powerful SIM cards. April 6.

56. People's Post and Telecom Daily. 2004b. The development of Chinese suppliers in 2003. January 29.

57. Peter B. 2003. Cisco: in hot pursuit of a Chinese rival. Business Week. May 19.

58. Qie Y. \& Li X. 2004. Huawei goes overseas. Jing Ji Dao Kan. May 25. http://finance.sina.com.cn/jyg1/20040525/1350777334.shtml accessed December $7,2004$. 
59. Qin B. 2002. Chinese telecommunication suppliers captured another fortress: data products. Economic Daily. September 5.

60. Qiu H., 2004. Chinese Telecommunication Network in 2003. The 21st Century Economy. February 4. http://www.cnii.com.cn/20030915/ca223427.htm . Accessed November 16, 2004.

61. RHK. 2004a. Global long distance WDM market share of 2003. http://www.huawei.com.cn/about/yeji.shtml Last examined December 19, 2004.

62. RHK. 2004b. Global market for the optical transmission of 2003. http://www.huawei.com.cn/about/yeji.shtml Last examined December 19, 2004.

63. RHK. 2004c. Global market for the integrated access networks of 2003. http://www.huawei.com.cn/about/yeji.shtml Last examined December 19, 2004.

64. Shi Y. 2000. The secrets of ZTE's rapid development. People's Post and Telecommunication Industry Market Weekly (Ren Min You Dian Chan Ye Shi Chang). October 10.

65. Sun L. 2002. Huawei: from wolf to lion. CEO\&CIO China. May 22.

66. Sun S. 2003. How does ZTE keep growing in the recession of telecommunication industry? Sohu IT. July 6. http://it.sohu.com/38/27/article210782738.shtml Accessed December 2, 2004. 
67. Tang X. 2003. It's painful to give up for GDT. The 21st Century Economy. http://news1.jri.com.cn/news/2003-03-28/000000532000.html . Accessed on November 20, 2004.

68. Telecommunication Information Weekly (Tongxin Xinxi). 2002. ZTE wants to lead in CDMA. December 24.

69. Wang X., 2002. Conversation: DTT is becoming a "wolf" from a "cow". China Electronics News. March 4.

70. Xiao R. 2003. Why is GDT left behind? People's Daily. Feb.10. http://www.snweb.com/gb/people daily/2003/02/10/p0210001.htm . Accessed on November 16, 2004.

71. Xin Z. \& Liu K. 1998. The current status and prediction about Chinese telecommunication high-tech industry. Global Science Research and Development. Vol. 3. http://chinainfo.gov.cn/data/200107/1 20010703 5886.html Accessed December $5,2004$.

72. Yao C. 2002. The restructures of Great Dragon Telecommunication: to rescue or to rebuild? People's Post and Telecom Daily, November 19: 8.

73. Yu S. 1999. GDT, DTT, ZTE and Huawei are the backbones of Chinese telecommunication industry. Beijing Youth Daily. March $1^{\text {st }}$.

74. Zhang W. \& Igel B. 2001. Managing the product development of China's SPC switch industry as an example of CoPS. Technovation 21 (6): $361-368$.

75. Zhong M.2002. The History of Chinese Telecommunication Switching Systems. Communications Weekly Journal. August 28. 
76. Zhu J. \& Pan Y. 2001. Why does GDT keep silent?

http://stock.163.com/editor/011010/011010 63039.html . Accessed November 16, 2004

77. ZTE. 2003. ZTE's three phases of development. http://www.zte.com.cn/about/about2-2.asp . Accessed November 1, 2003.

78. ZTE News Center. 2003. ZTE's business in 2002. March $12^{\text {th }}$. http://www.zte.com.cn/02news/detail.jsp?CateName=\%D0\%C2\%CE $\% \mathrm{C} 5 \% \mathrm{~B} 6 \%$ AF\%CC\%AC\&ID=2028 Accessed December 2, 2004. 


\section{APPENDICES}

Appendix A1: Key Events in the History of the Datang Telecom Technology Co., Ltd. (DTT)

\begin{tabular}{|c|c|}
\hline Year & Key Events \\
\hline 1998 & $\begin{array}{l}\text { - } \text { Founded on September } 21,1998 \\
\text { - Cooperated with Siemens in R\&D for the TD-SCDMA standard }\end{array}$ \\
\hline 1999 & $\begin{array}{l}\text { - Datang Optical Fiber factory was founded } \\
\text { - Datang R\&D (Beijing) Institute was founded } \\
\text { - Began R\&D on WCDMA }\end{array}$ \\
\hline 2000 & - Established a joint-lab with TI in Beijing to develop DSP technology \\
\hline 2001 & $\begin{array}{l}\text { - Cooperated with JAS (Korea) in CDMA area } \\
\text { - Top management is changed, Mr. Wei Shaojun becomes the new } \\
\text { president }\end{array}$ \\
\hline 2002 & - 2002.4 ERP was adopted in Xi'an Datang \\
\hline 2003 & - Grew capacity to manufacture SIM card \\
\hline
\end{tabular}

Sources:

1. DTT's website's introduction page: http://www.datang.com/intro/about.asp

2. DTT's history page: http://www.catt.ac.cn/intro/fzlc.asp

3. DTT's big events list page http://www.datang.com/news/event.asp

4. DTT's quality principles page:

http://www.datang.com/tech/techview.asp?id=66

Accessed November 29, 2004. 
Appendix A2: Products and Technology Developed by the Datang Telecom Technology Co., Ltd. (DTT)

\begin{tabular}{|l|l|}
\hline Year & Products and Technology Developed \\
\hline 1998 & SP-30 \\
& $\begin{array}{l}\text { GX2.5G/s WDM equipment } \\
\text { GSM switching system, CDMA switching system, SDH equipment, } \\
\text { digital microwave communication system, wireless access products. }\end{array}$ \\
\hline 2000 & $\begin{array}{l}\text { ICs and CDMA handsets' UIM cards } \\
\text { "R2000-II IP" broadband wireless LAN product }\end{array}$ \\
\hline 2001 & $\begin{array}{l}\text { Core router DTYH-ISR9108 } \\
\text { R2000AIRsun (3.5GHz) broadband wireless access equipment } \\
\text { Teleview/Msnet2.0 local telecommunication network management system } \\
\text { Telecommunication network billing system LBAS3.0 } \\
\text { CDMA mobile phones }\end{array}$ \\
\hline 2002 & $\begin{array}{l}\text { GX10N GPRS mobile phone with inside camera } \\
\text { OADM }\end{array}$ \\
\hline
\end{tabular}

Sources:

1. DTT's website's introduction page: http://www.datang.com/intro/about.asp 
2. DTT's history page: http://www.catt.ac.cn/intro/fzlc.asp

3. DTT's big events list page http://www.datang.com/news/event.asp

4. DTT's quality principles page:

http://www.datang.com/tech/techview.asp?id=66

Accessed November 29, 2004. 
Appendix A3: Employment, Revenue and Profits for the Datang Telecom Technology Co., Ltd. (DTT)

\begin{tabular}{|l|l|l|l|}
\hline & Employment & Gross Revenue (RMB) & Net Profit (RMB) \\
\hline 1998 & $2,800^{*}$ & 0.9 billion & 110 million \\
\hline 1999 & 3,172 & 1.08 billion & 115 million \\
\hline 2000 & 4,013 & 2.4 billion & 70 million \\
\hline 2001 & 4,962 & 2.05 billion & 36 million \\
\hline 2002 & 4,183 & 2.09 billion & 2.26 million \\
\hline 2003 & 3,482 & 1.76 billion & -187 million \\
\hline
\end{tabular}

Sources:

1. Employment for $1998 *$ is from (Zhong, 2002)

2. All other data obtained from DTT's annual reports. 


\section{Appendix B1: Key Events in the History of the Great Dragon Information Technology Co., Ltd. (GDT)}

\begin{tabular}{|c|c|}
\hline Year & Key Events \\
\hline 1995 & - Great Dragon Group was founded \\
\hline 1996 & - Company was restructured for the first time \\
\hline 1999 & $\begin{array}{l}\text { - GDT Information Science \& Technology Institution founded } \\
\text { - Cooperated with Israeli NBASE in data communications } \\
\text { - Company was restructured for the second time } \\
\text { - Founded a joint venture in Colombia }\end{array}$ \\
\hline 2000 & $\begin{array}{l}\text { - Signed cooperation agreement with Korean C\&S Technology Co. } \\
\text { - Signed cooperation agreement with Korean Space Co. }\end{array}$ \\
\hline 2002 & $\begin{array}{l}\text { - Beijing GDT Oriental International Information Technology Co., Ltd. was } \\
\text { established on September } 26 \\
\text { - Company was restructured for the third time }\end{array}$ \\
\hline 2003 & $\begin{array}{l}\text { - Beijing GDT Digital Technology Co., Ltd was established } \\
\text { - Beijing GDT Wireless Technology Co., Ltd. was established }\end{array}$ \\
\hline
\end{tabular}

Sources:

1. Stock Time Weekly. 2002. (Zheng Quan Shi Bao Cai Jing Zhou Kan). Great Dragon Restructured. November 27.

2. GDT's big events list: http://www.gdt.com.cn/about/index2.php

3. The news of GDT: http://www.gdt.com.cn/new/index.php 
Appendix B2: Products and Technologies Developed by the Great Dragon Information Technology Co., Ltd. (GDT)

\begin{tabular}{|c|c|}
\hline Year & Products and Technologies \\
\hline 1995 & - HJD-04 digital switching system, capacity was 50,000 lines \\
\hline 1996 & - HJD04-ISDN, HJD04D \\
\hline 1997 & $\begin{array}{l}\text { - HJD04-CIN, the first Chinese high capacity IN network } \\
\text { - V5.2 interface }\end{array}$ \\
\hline 1998 & $\begin{array}{l}\text { - GDC/GS2000 distributed mobile switching system } \\
\text { - GDT2000 broadband access network system }\end{array}$ \\
\hline 1999 & - Released data communication products \\
\hline 2000 & - N/A \\
\hline 2001 & $\begin{array}{l}\text { - GDT OpenIN - a new generation IN based on IP } \\
\text { - OmniRouter } 880 \text { and integrated access system } \\
\text { - VPN Version } 1.0 \text { software }\end{array}$ \\
\hline 2002 & - $\mathrm{N} / \mathrm{A}$ \\
\hline 2003 & - N/A \\
\hline
\end{tabular}

Sources:

1. GDT's big events list: http://www.gdt.com.cn/about/index2.php

2. The news of GDT: http://www.gdt.com.cn/new/index.php 


\section{Appendix B3: Employment, Revenue and Profits for the Great Dragon Information Technology Co., Ltd. (GDT)}

\begin{tabular}{|l|l|l|l|}
\hline & Employment & Gross Revenue (RMB) & Net Profit (RMB) \\
\hline 1994 & & & \\
\hline 1995 & & & \\
\hline 1997 & & & \\
\hline 1998 & $15,000^{* *}$ & 2.6 billion & 100 million \\
\hline $\mathbf{1 9 9 9}$ & & 1.2 billion & 35 million * \\
\hline $\mathbf{2 0 0 0}$ & & & -90 million \\
\hline $\mathbf{2 0 0 1}$ & & 0.35 billion & \\
\hline $\mathbf{2 0 0 2}$ & & & \\
\hline $\mathbf{2 0 0 3}$ & 3,200 & & \\
\hline
\end{tabular}

Sources:

1. * is from Chinese Top 100 Electronics Company List of 2000

2. ** is from (Zhong, 2002)

3. Other data are from People's Daily. 2002. Why is the difference so big? May

$13^{\text {th }}$. http://news.xinhuanet.com/newscenter/2002-05/13/content $390363 . \mathrm{htm}$ Accessed Nov. 29, 2004. 
Appendix C1: Key Events in the History of Huawei Technologies (Huawei)

\begin{tabular}{|c|c|}
\hline Year & Key Events \\
\hline 1988 & $\begin{array}{l}\text { Was founded in Shenzhen in 1988, registered capital was RMB 21,000 } \\
\text { (CDN \$3,500). Only had } 6 \text { shareholders, did not have its own product or } \\
\text { technology, acted as an agent of foreign country's PBXs--HAX in Chinese } \\
\text { market }\end{array}$ \\
\hline 1991 & $\begin{array}{l}\text { - Huawei decided to develop its own telecommunication equipment like } \\
\text { JK1000 }\end{array}$ \\
\hline 1992 & - Began to develop its own digital voice exchange, the $\mathrm{C} \& \mathrm{C} 08$ \\
\hline 1993 & - Built an ASIC research institute in California, US \\
\hline 1994 & - C\&C08 was formally released to the Chinese market \\
\hline 1995 & $\begin{array}{l}\text { Established the Protocol Software Department in Shenzhen to explore the } \\
\text { direction of future developments in data communications } \\
\text { - Established two research institutes in Beijing and Shanghai; Beijing for data } \\
\text { communication products and Shanghai for mobile communication products } \\
\text { - Passed the ISO-9001 certification }\end{array}$ \\
\hline 1996 & $\begin{array}{l}\text { - Employees began to discuss "Huawei Basic Law" } \\
\text { - Founded Capital Administration Department to be responsible for } \\
\text { company's investments } \\
\text { - Founded Huawei Electrics Co., later the name was changed to Avansys } \\
\text { Power Electrics Co. } \\
\text { - "Marketing Dept. Resigned Together" event. Every employee in the } \\
\text { marketing department had to hand in two statements. One was a work } \\
\text { statement, the other was a resignation letter. Only one was accepted. }\end{array}$ \\
\hline 1997 & $\begin{array}{l}\text { - The President of Huawei, Mr. Ren Zhengfei, visited executives of IBM, } \\
\text { Hughes, Bell Labs and HP } \\
\text { - Established a joint-venture in Russia }\end{array}$ \\
\hline 1998 & $\begin{array}{l}\text { - Released the final version of "Huawei's Basic Law" } \\
\text { - Established joint-ventures with Chinese customers to secure investment } \\
\text { funds and scheduled payments }\end{array}$ \\
\hline
\end{tabular}




\begin{tabular}{|c|c|}
\hline & $\begin{array}{l}\text { - Established the Data Communications Sales Department to sell exclusively } \\
\text { in data products } \\
\text { - Established the Sales Channel Development Department } \\
\text { - Started to execute a large scale employee recruitment plan } \\
\text { - Applied the National Vocational Qualifications standards inside the } \\
\text { company }\end{array}$ \\
\hline 1999 & $\begin{array}{l}\text { - IBM helped Huwaei reform its Integrated Product Development (IPD) and } \\
\text { Integrated Supply Chain processes } \\
\text { - HayGroup, PriceWaterhouseCoopers, FraunhoferGesellschaft helped the } \\
\text { company improve efficiency } \\
\text { - Established a research institute in Dallas, Texas } \\
\text { - Established a data communications product line. } \\
\text { - Applied the Software Engineering Institute's Capability Maturity Model } \\
\text { (CMM) for software development. }\end{array}$ \\
\hline 2000 & $\begin{array}{l}\text { - Recruited experienced foreign managers and experts } \\
\text { - Established a sales channel system, and used it to sell data products through } \\
\text { distributors } \\
\text { - Established the Enterprise Networks division }\end{array}$ \\
\hline 2001 & $\begin{array}{l}\text { - Established an information security department to protect business secrets } \\
\text { and patents } \\
\text { - Reformed business share structure through cooperation with Towers Perrin } \\
\text { Co. } \\
\text { - Sold Avansys Power Electric Co. to Emerson Electrics Co. for US } \$ 750 \\
\text { million } \\
\text { - Deployed Siemens' Warehouse Management System to improve efficiency } \\
\text { and quality at a cost of RMB } 100 \text { million }\end{array}$ \\
\hline 2002 & $\begin{array}{l}\text { - All top managers were trained by eight professors from Chinese famous } \\
\text { universities } \\
\text { - Entered the Operational Support System (OSS) business transforming the } \\
\text { company from being a pure equipment supplier to being an equipment and } \\
\text { service supplier }\end{array}$ \\
\hline
\end{tabular}




\begin{tabular}{|c|c|}
\hline & $\begin{array}{l}\text { - Established Cosmobic Technology Co. in Shanghai, a joint-venture with } \\
\text { NEC and Panasonic to develop } 3 \mathrm{G} \text { mobile phones } \\
\text { - Obtained warrants on } 3 \mathrm{G} \text { patents covering network equipment and mobile } \\
\text { phones from Telefon AB LM Ericsson } \\
\text { - Stepped into the } 3 \mathrm{G} \text { mobile terminal equipment market } \\
\text { - Established a subsidiary company, Futurewei in Texas, US. } \\
\text { - Passed TL9000 certification }\end{array}$ \\
\hline 2003 & $\begin{array}{l}\text { - Established a joint-venture with Siemens to undertake TD-SCDMA's R\&D } \\
\text { - Established a joint-venture with } 3 \text { COM to develop data communication } \\
\text { products } \\
\text { - Cooperated with Infineon Technologies Co. to develop a low-cost R\&D } \\
\text { platform for WCDMA mobile phone } \\
\text { - Research institutes in Beijing and Nanjing received CMM4 certificates } \\
\text { - Research institute in India received CMM5 certificate } \\
\text { - Joined a Common Public Radio Interface (CPRI) alliance with Ericsson, } \\
\text { Nortel, NEC and Siemens }\end{array}$ \\
\hline
\end{tabular}

Sources:

1. Business Report of Netease. 2002. The Growing Pain of Huawei. Oct.10.

2. CEO \& CIO China. 2000. Huawei: a small step, a big step. Oct. 13. http://finance.sina.com.cn/2000-10-13/16674.html .Accessed Nov. 29, 2004.

3. Cheng D. \& Liu L., 2003. The Truth of Huawei. Beijing: Contemporary China Press.

4. Computer Partner World. 2002. Huawei: A Black Horse in Network. Oct. 08. http://www.cpw.com.cn/cpwnew/news_v.asp?id=20021008012 Accessed Nov. $29,2004$.

5. Ouyang J. 2003. Huawei: improve itself in the international competition. 
Tongxin Xinxi Weekly. Dec.30.

http://www.huawei.com.cn/news/media/1644.shtml Accessed Nov. 29, 2004.

6. Wu J. 2004a. Group Resign and Inner Growth. CEO \& CIO China, 4. http://www.newmarketing.cn/2004/03/05/20040305-20290-1.shtml Accessed Nov. 29, 2004.

7. Wu J. 2004b. Who and Where Is Huawei's Successor. CEO \& CIO China, 20.

8. Yang X. 2002. The Road of Huawei's CMM. CEO \& CIO China, 2. http://www.ceocio.com.cn/issues/2002/2/text/t 2 13.asp Accessed Nov. 29, 2004. 


\section{Appendix C2: Products and Technologies Developed by Huawei Technologies (Huawei)}

\begin{tabular}{|c|c|}
\hline YEAR & Products and Technologies \\
\hline 1988 & - HAX (Huawei was an agent of foreign country's PBX - HAX) \\
\hline 1991 & $\begin{array}{l}\text { Decided to develop own telecommunication equipment, invested } \\
\text { the profit from PBXs to R\&D department. }\end{array}$ \\
\hline 1992 & - JK-1000 \\
\hline 1992 & - Began to develop its own brand digital voice exchange C\&C08 \\
\hline 1994 & $\begin{array}{l}\text { - } \mathrm{C} \& \mathrm{C} 08 \mathrm{~A} \\
\text { - } \mathrm{ETS}-450\end{array}$ \\
\hline 1995 & $\begin{array}{l}\text { - } \quad \text { STP equipment } \\
\text { - Started R\&D of mobile and data technology. }\end{array}$ \\
\hline 1996 & $\begin{array}{l}\text { - HONET } \\
\text { - Quidway } 2501 \text { Access Router }\end{array}$ \\
\hline 1997 & $\begin{array}{l}\text { - GSM } \\
\text { - Quidway S2403 Ethernet Switch } \\
\text { - Got a break-through in the technology of access routers, by Huawei } \\
\text { (Beijing) institute. }\end{array}$ \\
\hline 1998 & $\begin{array}{l}\text { - } \text { CDMA WLL } \\
\text { - } \text { QuidwayA8010 Router for Telecom Networks } \\
\text { - } \text { Began the R\&D in WCDMA }\end{array}$ \\
\hline 1999 & $\begin{array}{l}\text { - QuidwayR3640 QuidwayR3680 } \\
\text { - Invested } 20 \text { million RMB to develop core routers and Ethernet } \\
\text { switches }\end{array}$ \\
\hline 2000 & $\begin{array}{l}\text { - STM-64 } \\
\text { - Quidway NetEngine } 16 / 08 \text { Routers } \\
\text { - Designed over } 40 \text { kinds of ASIC chips, manufacturing capacity was } \\
5 \text { million chips per year, improved design capability from } 0.5 \\
\text { micron to } 0.18 \text { micron. }\end{array}$ \\
\hline 2001 & - Quidway NetEngine80; QuidwasS Ethernet switch \\
\hline
\end{tabular}




\begin{tabular}{|c|c|}
\hline YEAR & Products and Technologies \\
\hline 2002 & $\begin{array}{l}\text { - } \text { C\&C08iNET } \\
\text { - } \text { ViewPoint8000 } \\
\text { - } \text { NGN equipment } \\
\text { - } \text { WCDMA } \\
\text { - CDMA2000 } 1 \text { X EV-DO, } \\
\text { - } \text { SBS2500 } \\
\text { - } \text { DWDM(360G) } \\
\text { - } \text { Quidway NetEngine40, NetEngine5000, } \\
\text { - } \text { QuidwayS8500 } \\
\text { - } \text { IPDSLAM, } \\
\text { - } \text { TELLIN IN, MMS equipment, InfoX, SMS equipment, OSS/BSS. }\end{array}$ \\
\hline 2003 & $\begin{array}{l}\text { - U-SYS NGN, } \\
\text { - VoIP equipment } \\
\text { - } \text { WCDMA R4 system, } \\
\text { - } \text { Made successful WCDMA video calls based on IP } \\
\text { - } \text { SuperWDM } \\
\text { - } \text { MSTP } \\
\text { - } \text { PHS, } 3 \text { G mobile phones. } \\
\text { - } \text { ASIC design capability achieved } 0.13 \text { micron; could produce whole } \\
\text { set of ICs of WCDMA R4. }\end{array}$ \\
\hline
\end{tabular}

Sources:

1. Cheng D. \& Liu L., 2003. The Truth of Huawei. Beijing: Contemporary China Press.

2. Computer Partner World. 2002. Huawei: A Black Horse in Network. Oct. 08. http://www.cpw.com.cn/cpwnew/news v.asp?id=20021008012 Accessed Nov. 29, 2004.

3. Huawei News Center. 2003. Huawei Can Produce New Generation 
WCDMA ASIC Series. Aug. 04.

http://www.huawei.com.cn/news/newscenter/1440.shtml Accessed Nov. 29, 2004. 
Appendix C3: Employment, Revenue and Profits for Huawei Technologies (Huawei)

\begin{tabular}{|c|c|c|c|}
\hline & Number of Employees & $\begin{array}{l}\text { Annual Revenue } \\
\text { (Billion RMB) }\end{array}$ & $\begin{array}{l}\text { Gross Profit } \\
\text { (Billion RMB) }\end{array}$ \\
\hline 1988 & 14 & & \\
\hline \multicolumn{4}{|l|}{1989} \\
\hline \multicolumn{4}{|l|}{1990} \\
\hline 1991 & 20 & & \\
\hline 1992 & 200 & 0.1 & \\
\hline 1993 & 600 & 0.41 & \\
\hline 1994 & 800 & 0.8 & \\
\hline 1995 & 1800 & 1.4 & \\
\hline 1996 & 2300 & 2.6 & \\
\hline 1997 & 5600 & 4.1 & \\
\hline 1998 & 8000 & 8.9 & \\
\hline 1999 & 15000 & 12 & $1.7^{* *}$ \\
\hline 2000 & 16000 & 22 & $2.9^{* * *}$ \\
\hline 2001 & $23000^{*}$ & 25.5 & $2.7 * *$ \\
\hline 2002 & $22000^{*}$ & 22.1 & $1.2^{* * *}$ \\
\hline 2003 & 22000 & 31.7 & $3.8 * * *$ \\
\hline
\end{tabular}


Sources:

1. ${ }^{*}$ is from Wu J. 2004. Huawei: Group resigns and reform. CEO\&CIO

China. March $5^{\text {th }}$. http://www.newmarketing.cn/2004/03/05/2004030520290-1.shtml Accessed Dec.9, 2004.

2. ** is from Chinese Top 100 Electronics Company List 2000-2003

3. *** is from http://tech.sina.com.cn/it/t/2004-05-26/0941367248.shtml

4. All other data are from Cheng D. \& Liu L., 2003. The Truth of Huawei. Beijing: Contemporary China Press. 
Appendix D1: Key Events in the History of the Zhongxing Telecommunication Equipment Co., Ltd. (ZTE)

\begin{tabular}{|c|c|}
\hline Year & Key Events \\
\hline 1985 & $\begin{array}{l}\text { - ZTE Semiconductor Co. was founded in Shenzhen. Shareholders were } \\
\text { Aerospace Ministry Plant 691, Hong Kong Yunxing Co. and Great Wall } \\
\text { Shenzhen Co. }\end{array}$ \\
\hline 1986 & $\begin{array}{l}\text { - Shenzhen Research Institute was established to develop the voice PBX } \\
\text { ZX-60 }\end{array}$ \\
\hline 1987 & $\begin{array}{l}\text { - Cooperated with Beijing University of Post and Telecommunications to } \\
\text { develop a digital voice PBX }\end{array}$ \\
\hline 1993 & $\begin{array}{l}\text { - ZTE's shareholders became Aerospace Ministry Plant 691, Guangyu } \\
\text { Group Co. and Weixian Telecommunication Co. } \\
\text { - ZTE Nanjing Research Institute was established to develop high capacity } \\
\text { exchanges for PSTN }\end{array}$ \\
\hline 1994 & $\begin{array}{l}\text { - ZTE Shanghai Research Institute was established to develop wireless and } \\
\text { access products }\end{array}$ \\
\hline 1995 & - Passed the ISO-9001 certification \\
\hline 1996 & $\begin{array}{l}\text { - Started R\&D for broadband data products } \\
\text { Commitment to three strategies is made: } \\
\text { 1. Product category: changing from single switching system to multiple } \\
\text { products like switching, transmission, access, and power equipment } \\
\text { 2. Domestic market: spread from rural areas to urban network } \\
\text { 3. Prepare to spread from Chinese market to overseas market }\end{array}$ \\
\hline 1997 & $\begin{array}{l}\text { - ZTE was modified to become a public company that can be listed in } \\
\text { Chinese stock exchange }\end{array}$ \\
\hline 1998 & $\begin{array}{l}\text { - ZTE Shanghai No.2 Research Institution was established to develop } \\
\text { GSM } \\
\text { - Established with Texas Instrument Co., the TI-ZTE DSP lab in Shenzhen } \\
\text { - Established research institutes in New Jersey, San Diego and California }\end{array}$ \\
\hline
\end{tabular}




\begin{tabular}{|c|c|}
\hline & $\begin{array}{l}\text { to track the latest technologies in soft switching and CDMA2000 1x } \\
\text { - ZTE Beijing Research Institute was established to develop optical } \\
\text { DWDM products and technologies }\end{array}$ \\
\hline 1999 & $\begin{array}{l}\text { - Established a joint-venture in Pakistan } \\
\text { - Established a joint lab with Motorola in Nanjing focused on data and } \\
\text { mobile communications }\end{array}$ \\
\hline 2000 & $\begin{array}{l}\text { - ZTE (Korea) Institute was established to develop CDMA products } \\
\text { - ZTE (Xi'an) Institute was established to develop RF devices and } \\
\text { intelligence antennas } \\
\text { - ZTE IC Design Co. was established } \\
\text { - ZTE (Chongqing) Institute was established to develop intelligent } \\
\text { networks and network administration products } \\
\text { - R\&D lab and manufacturing plant were established in Nanjing. } \\
\text { - The year was declared to be the "Year of Speed", development needed to } \\
\text { be undertaken at a faster rate }\end{array}$ \\
\hline 2001 & $\begin{array}{l}\text { - ZTE founded a joint-venture with Congo, this is the first time ZTE acts } \\
\text { as a telecommunication service provider overseas } \\
\text { - ZTE (Hong Kong) was founded to act as a material import and export } \\
\text { agent, financial service and a platform in Hong Kong } \\
\text { - Passed ISO } 9001 \\
\text { - Deployed CMM, e business, ERP, ECC, CPC and } 6 \sigma \\
\text { - Began to compete overseas in a large scale } \\
\text { - The year was declared to be the "Year of Quality" }\end{array}$ \\
\hline 2002 & $\begin{array}{l}\text { - "ZTE and Universities Strategic Cooperation Committee" was } \\
\text { established } \\
\text { - ZTE (Guangzhou) Co. was established } \\
\text { - ZTE and Intel (China) agreed to cooperate in the areas of } 3 \mathrm{G} \text { wireless } \\
\text { communication and wireless LANs } \\
\text { - Established a joint-lab with Agere Co. to cooperate in the fields of } \\
\text { microelectronics, optoelectronics, data and transmission } \\
\text { - ZTE Global Customer Support Center was established in Shenzhen to }\end{array}$ \\
\hline
\end{tabular}




\begin{tabular}{|c|c|}
\hline & $\begin{array}{l}\text { provide } 7 \times 24 \text { hotline services } \\
\text { - Core Administration Committee was established to make decisions } \\
\text { quickly for the purpose of adapting to market changes } \\
\text { - Moved Sales Division from Shenzhen to Beijing, where all service } \\
\text { providers are headquartered } \\
\text { - Merged Network and Optical Switching departments } \\
\text { - Established the Mobile Phone Department } \\
\text { - The year was declared the "Year of Work Flow Optimization" }\end{array}$ \\
\hline 2003 & $\begin{array}{l}\text { - Agreed to cooperate with IBM (China) in the areas of finance, } \\
\text { technology, R\&D, work flow modification and operating overseas } \\
\text { - Established an R\&D institute in Sweden } \\
\text { - Agreed to cooperate with Microsoft (China) in the telecommunication } \\
\text { field. } \\
\text { - Built a 36-level building in Shenzhen to be used as ZTE's R\&D center } \\
\text { - The year was declared to be the "Year of Execution" }\end{array}$ \\
\hline
\end{tabular}

Sources:

1. ZTE's website of introduction: http://www.zte.com.cn/01about/index.jsp Accessed Nov. 29, 2004.

2. ZTE's website of big events list: http://www.zte.com.cn/01about/index3 3.jsp Accessed Nov. 29, 2004.

3. ZTE's website of three developing stages: http://www.zte.com.cn/01about/index3_2.jsp Accessed Nov. 29, 2004.

4. Kang K. 2003. ZTE is building a "lifeline" project. People's Post and Telecom Daily, Nov. 14. http://www.cnii.com.cn/20030915/ca206512.htm Accessed Nov. 29, 2004.

5. Lu Z. 2002a. ZTE's development. People’s Post and Telecom Daily, Feb. 5. 
6. Lu Z. 2002b. ZTE keeps growing. Telecommunication Industry Daily, May 15. 
Appendix D2: Products and Technologies Developed by Zhongxing Telecommunication Equipment Co., Ltd. (ZTE)

\begin{tabular}{|c|c|}
\hline Year & Products and Technologies \\
\hline $1985 \sim 1986$ & $\begin{array}{l}\text { Digital watch, phone set, ZTE had nothing to do with } \\
\text { telecommunication products }\end{array}$ \\
\hline 1987 & - $\mathrm{PBX} Z \mathrm{ZX}-60$ \\
\hline 1990 & - Digital PBX ZX-500, the first Chinese digital PBX exchange \\
\hline 1991 & - Digital ZX-500A for PSTN \\
\hline 1993 & $\begin{array}{l}\text { ZXJ -2000 digital exchange for PSTN and ZXJ-2000A for private } \\
\text { customers }\end{array}$ \\
\hline 1994 & - Began R\&D in access networks and wireless communications \\
\hline 1995 & - ZXJ10 digital exchange with a capacity of 170,000 subscriber lines \\
\hline 1996 & - Began R\&D in broadband and data products \\
\hline 1997 & - ZXA10 Access Network \\
\hline 1998 & - Began R\&D in GSM, Softswitch, CDMA2001x, and optical DWDM \\
\hline 1999 & $\begin{array}{l}\text { - } \text { ZXMVC3000 (video conference) } \\
\text { - } \text { ZTE GSM900/1800 system } \\
\text { - } \text { CDMA Switching System }\end{array}$ \\
\hline 2000 & $\begin{array}{l}\text { - } \text { Intelligent network } \\
\text { - } \text { ZXIP-AS(Internet Access Server), } \\
\text { - } \text { GSM 900/1800 mobile phones } \\
\text { - } \text { CDMA Base Station, mobile phones } \\
\text { - ZXC10 CDMA mobile communication system }\end{array}$ \\
\hline 2001 & $\begin{array}{l}\text { - } \text { Unitrans optical transmission system } \\
\text { - } \text { Billiken iDEN billing system } \\
\text { - } \text { ZXR10 core router } \\
\text { - } \text { ZTE Softswitch - soft switch system } \\
\text { - } \text { VoIP billing system } \\
\text { - } \quad \text { Developed CDMA2000 successfully }\end{array}$ \\
\hline
\end{tabular}




\begin{tabular}{|c|c|}
\hline 2002 & 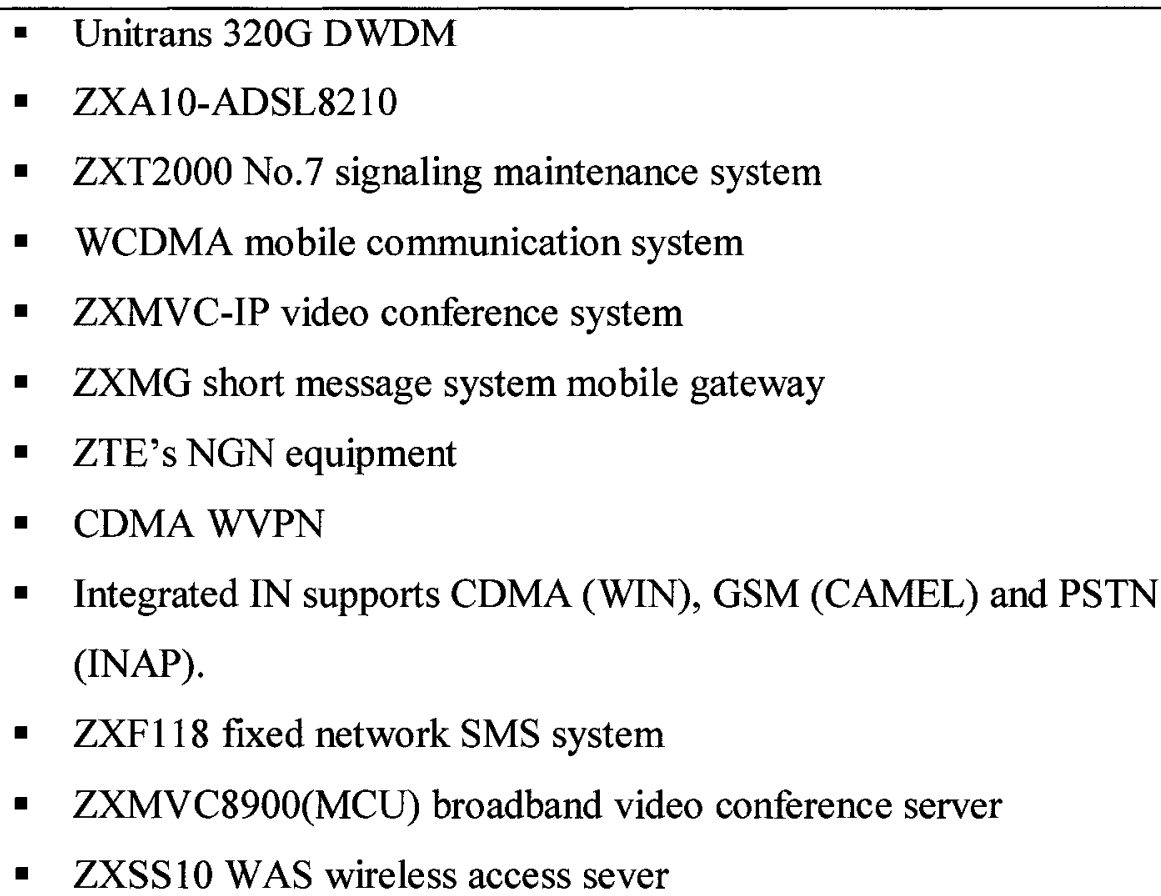 \\
\hline 2003 & $\begin{array}{l}\text { - "AnyService" multimedia customer service center } \\
\text { - ZXBWA 3.5G broadband wireless access products } \\
\text { - CDMA2000 1x EV/DO (HDR) } \\
\text { - CDMA WLL products } \\
\text { - "Little Smart" PHS phone market share in China is } 40 \%\end{array}$ \\
\hline
\end{tabular}

Sources:

1. Cheng D. \& Liu L., 2003. The Truth of Huawei. Beijing: Contemporary China Press.

2. ZTE's website of introduction: http://www.zte.com.cn/01about/index.jsp

3. ZTE's website of big list: http://www.zte.com.cn/01about/index3 3.jsp

4. ZTE's website of three developing stages: http://www.zte.com.cn/01about/index3 2.jsp

5. Kang K. 2003. ZTE is building a "lifeline" project. People's Post and 
Telecom Daily, Nov. 14.

6. Telecommunication Information Daily. 2002. ZTE is leading in CDMA.

Dec.24. http://tel.21cn.com/market/2002-12-24/883237.html Accessed Nov. 29,2004 . 
Appendix D3: Employment, Revenue and Profits for Zhongxing Telecommunication Equipment Co., Ltd. (ZTE)

\begin{tabular}{|l|c|c|c|}
\hline & Employment & Gross Revenue (RMB) & Net Profit (RMB) \\
\hline $\mathbf{1 9 8 5}$ & & 350,000 & \\
\hline $\mathbf{1 9 8 8}$ & & 5.17 million & \\
\hline $\mathbf{1 9 9 2}$ & & 94 million & \\
\hline $\mathbf{1 9 9 6}$ & & 309 million & 99 million \\
\hline $\mathbf{1 9 9 7}$ & & 631 million & 114 million \\
\hline $\mathbf{1 9 9 8}$ & 5,420 & 1.97 billion & 309 million \\
\hline $\mathbf{1 9 9 9}$ & 6,777 & 2.5 billion & 211 million \\
\hline $\mathbf{2 0 0 0}$ & 9,377 & 4.5 billion & 354 million \\
\hline $\mathbf{2 0 0 1}$ & 12,961 & 9.33 billion & 570 million \\
\hline $\mathbf{2 0 0 2}$ & 12,916 & 11 billion & 567 million \\
\hline $\mathbf{2 0 0 3}$ & 17,000 & 16 billion & 752 million \\
\hline
\end{tabular}

Sources: Data for 1996 2003 is from annual reports, and others are from ZTE's website. 
Appendix E: Ranking of Shanghai Bell, BISC, Huawei, ZTE, DTT and GDT in the Chinese TOP 100 Electronics Company List (RMB: Billion)

\begin{tabular}{|c|c|c|c|c|c|c|c|c|c|c|c|c|}
\hline \multirow[t]{2}{*}{ Year } & \multicolumn{2}{|c|}{$\begin{array}{l}\text { Shanghai } \\
\text { Bell }\end{array}$} & \multicolumn{2}{|c|}{ BISC } & \multicolumn{2}{|c|}{ Huawei } & \multicolumn{2}{|c|}{$\overline{\text { ZTE }}$} & \multicolumn{2}{|l|}{ DTT } & \multicolumn{2}{|c|}{ GDT } \\
\hline & $\begin{array}{l}\text { त्र } \\
\text { 崖 }\end{array}$ & 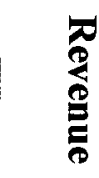 & 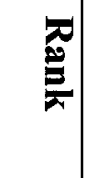 & 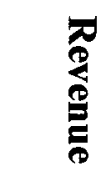 & 忽 & 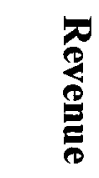 & 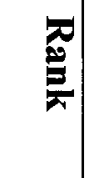 & 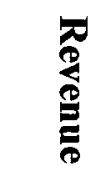 & 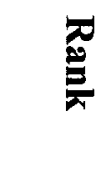 & 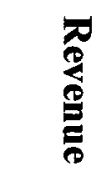 & 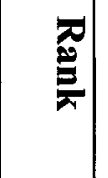 & 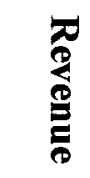 \\
\hline 1992 & 5 & 1.32 & 73 & 0.19 & & & & & & & & \\
\hline 1993 & 6 & 2.83 & 19 & 1.1 & & & & & & & & \\
\hline 1994 & 2 & 5.12 & 14 & $\begin{array}{l}1.57 \\
\end{array}$ & & & & & & & & \\
\hline 1995 & 7 & 4.55 & 33 & 1.02 & 26 & 1.27 & & & & & & \\
\hline 1996 & 8 & 4.57 & 24 & 1.72 & & & & & $84 *$ & 0.37 & & \\
\hline 1997 & 12 & 5.00 & 28 & 1.99 & 18 & 4.19 & & & $89 *$ & 0.42 & & \\
\hline 1998 & 12 & 6.05 & 21 & 2.92 & 10 & 7.18 & & & $68^{*}$ & 0.63 & 28 & 2.60 \\
\hline 1999 & 11 & 8.65 & 31 & 2.55 & 10 & 10.2 & & & 58 & 1.09 & 54 & 1.20 \\
\hline 2000 & 12 & 10.8 & 32 & 3.1 & 8 & 15.2 & 22 & 4.5 & 36 & 2.9 & & \\
\hline 2001 & 9 & 15.1 & 26 & 4.0 & 7 & 16.2 & 11 & 10.9 & 32 & 3.16 & & \\
\hline 2002 & 12 & 11.1 & 63 & 1.58 & 7 & 17.2 & 11 & 12.5 & 40 & 2.65 & & \\
\hline 2003 & 17 & 9.7 & 69 & 1.8 & 7 & 21.7 & 10 & 17.5 & & & & \\
\hline
\end{tabular}

* Revenue is for Xi'an Datang, the predecessor of DTT. DTT was founded in September 1998.

Source: Chinese Top 100 Electronics Company List, http://www.ittop100.gov.cn/search?channelid=1270\&templet=outline.jsp 
Appendix F: Number of Chinese Subscribers to Fixed, Mobile and Internet Services (1991 - 2003)

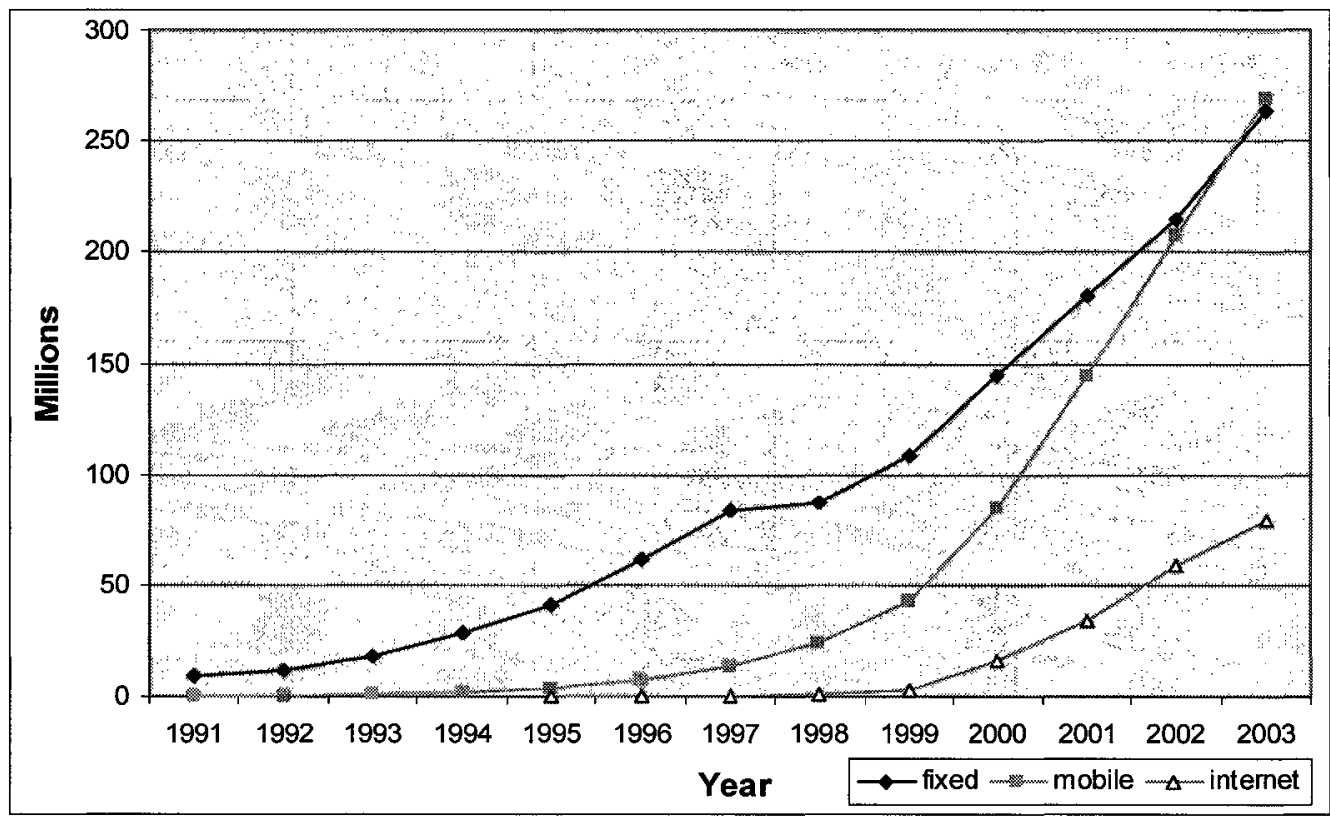

Source: Ministry of Information Industry, 1991 - 2003 
Appendix G: Investment in Telecommunications Made by the Ministry of Information Industry of China*

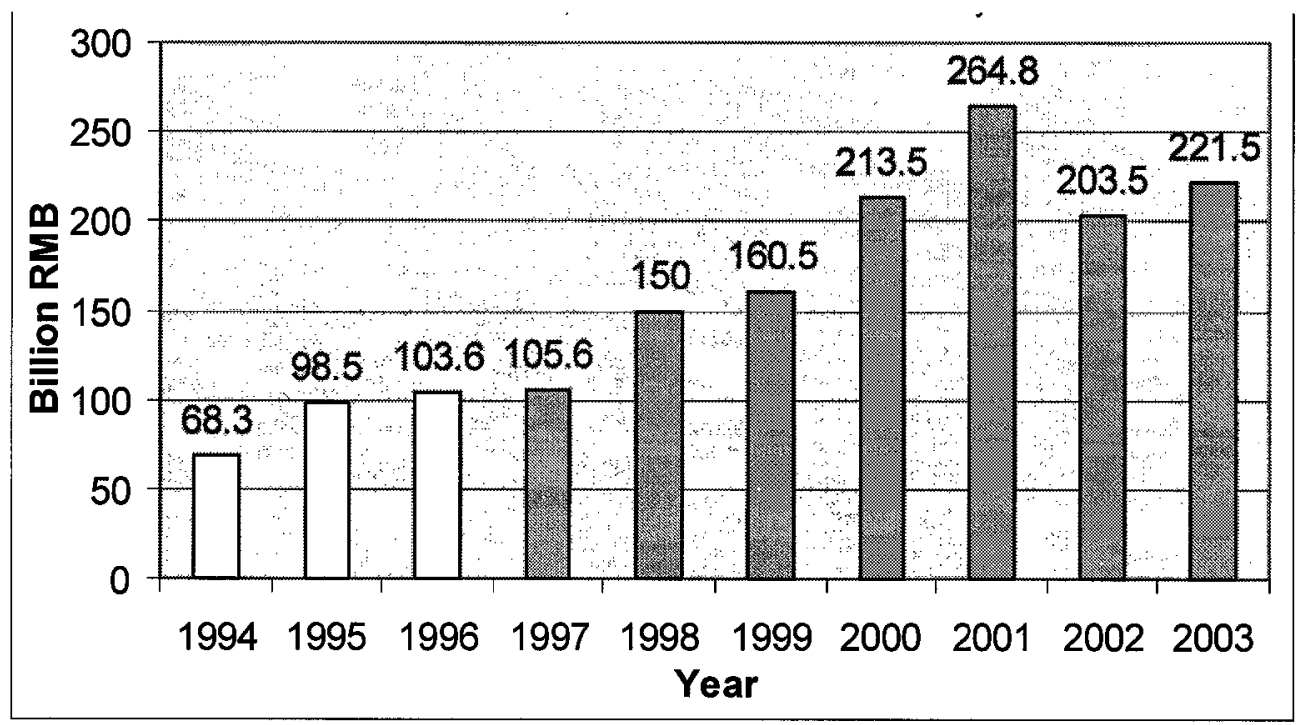

* Data for 1994, 1995 and 1996 include investment in post as well as telecommunications. All other years, data shows only investment in telecommunications.

Source: Ministry of Information Industry, 1994 - 2003. 


\section{Appendix H: International Standards}

\section{CMM}

Carnegie Mellon University's Software Engineering Institute (SEI) created the Capability Maturity Model (CMM).

CMM offers a model for judging the software processes of an organization and for identifying key practices required to increase the maturity of these processes. It establishes a successful means for modeling, defining, and measuring the maturity of the processes used by software professionals.

\section{ISO 9000}

International Organization for Standardization (ISO) 9000, ISO 9000 has become an international reference for quality management requirements in business-to-business dealings.

\section{ISO 9001, ISO 9002, ISO 9003}

ISO 9001 is part of the ISO 9000 family of standards. The new ISO 9001:2000 designation comprises the ISO 9001, ISO 9002, and ISO 9003 standards. ISO 9001 targets the manufacturing process, although it also includes manufacturing services and software development. 
- ISO 9001 sets out the requirements for an organization whose business processes range all the way from design and development, to production, installation and servicing.

- ISO 9002 does not include the design control requirements of ISO 9001 otherwise, its requirements are identical.

- ISO 9003 is the standard for an organization whose business processes do not include design control, process control, purchasing or servicing, and which basically uses inspection and testing to ensure that final products and services meet specified requirements.

\section{ISO 14000}

ISO 14000 is a series of international standards on environmental management. It provides a framework for the development of an environmental management system and the supporting audit program.

\section{ISO 14001}

ISO 14001 is the corner stone standard of the ISO 14000 series. It specifies a framework of control for an Environmental Management System against which an organization can be certified by a third party. 


\section{TL 9000}

TL 9000 is a quality management system for design, development, production, delivery, installation and maintenance of telecommunication products and services. The TL 9000 Quality System requirements include a minimum set of performance metrics and indicators to measure progress and evaluate results of the quality system implementation. The new TL 9000 became effective March 30, 2001 and comprises the ISO 9001:2000 quality system requirements (released December 15, 2000) supplemented by additional quality system requirements established by the telecommunications industry.

\section{CPC}

Collaborative Product Commerce (CPC) is a class of software and services that uses Internet technologies to permit individuals-no matter what role they have in the commercialization of a product, no matter what computer-based tools they use, no matter where they are located geographically or within the supply net-to collaboratively develop, build, and manage products throughout the entire lifecycle. Using a standard browser, an authorized CPC user can review information from an extended-enterprise information system 'view' that operates across a dispersed set of heterogeneous product development resources. These resources typically reside in multiple information repositories and are derived from independently implemented and maintained systems. 


\section{ERP}

Enterprise Resource Planning (ERP) attempts to integrate all departments and functions across a company to create a single software program that runs off one database.

2. IPD

Integrated Product Development (IPD) is a new name for Concurrent Engineering. IPD was first proposed by the U.S. Department of Defense as a name which better reflects the participation of manufacturing and other downstream functions in product development. IPD is a management strategy that uses customer inquiry, crossfunctional teaming and technology integration to improve the performance of product development lifecycles. In IPD, the organization moves toward a totally electronic representation of the product and its processes. The focus of data is components and their features, not simply electronic representation of drawings. This allows early sharing of data and greater concurrency in the product development lifecycle. Sharing can proceed before the availability of approved design "drawings".

3. ISC 
Integrated Supply Chain (ISC) includes all people and their respective firms that are part of the life cycle of products and services provided by the chain. Such an approach can not be functionally driven since ISC is the responsibility of all functions. The ISC approach accounts for all firms involved from mother earth through to the end customer.

\section{WMS}

Warehouse Management System (WMS) The primary purpose of a WMS is to control the movement and storage of materials within an operation and process the associated transactions. Directed picking, directed replenishment, and directed putaway are the key to WMS.

5. National Vocational Qualification (NVQ)

The Review of Vocational Qualifications in England and Wales (RVQ) Working Group report in April 1986 recommended the introduction of NVQs to address weaknesses in the then current systems of vocational qualifications.

National vocational qualifications (NVQs) are work-related, competence-based qualifications. They reflect the skills and knowledge needed to do a job effectively, 
and show that a candidate is competent in the area of work the NVQ framework represents. 